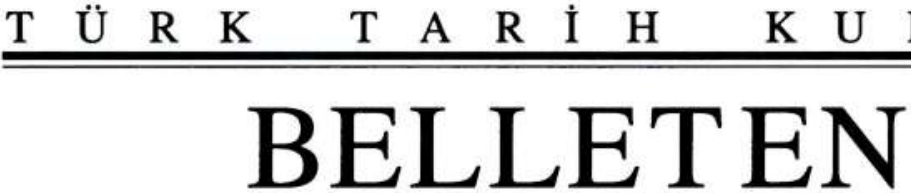

\section{ORTA KARADENIZ BÖLGESI PROTOHISTORIK ÇAĞ MADEN SANATININ KÖKENI VE GELIŞIMI}

\section{ÖNDER BILGI*}

Orta Karadeniz Bölgesi'nde Protohistorik Çağ'da yani İÖ 4500 ile İÖ 500 yılları arasını kapsayan yaklaşık 4000 yıllık bir zaman süreci içinde maden sanatının ortaya çıkışı ile nasıl bir gelişim gösterdiğinin ayrıntları ile araşurılması ve bu bölge maden sanatının Anadolu maden sanatıdaki yeri ile komşu ülkelerin çağdaş kültürlerinin maden sanatları ile ilişkilerinin ortaya konması amaçlı proje ile çerçevesindeki çalışmalar 3 aşamalı olarak 1997, 1998 ve 1999 yıllarında gerçekleştirildi.

\section{DÖNEMI ÇALIŞMALARI}

1997 yılında geliştirilen Birinci Proje ${ }^{1}$ ile ilgili çalışmalar 3 aşamalı olarak 16.06.1997 ile 26.09.1997 tarihleri arasında gerçekleştirildi.

1997 dönemi projesinin 1. Aşamasını oluşturan İkiztepe örenyerindeki kazı çalışmaları 07 Temmuz ile 29 Ağustos 1997 tarihleri arasında 55 gün süre ile gerçekleştirildi ${ }^{2}$. Tepe III'te (Res.1) yer alan "L" açmasının D 6-11/I

* İÜ Edebiyat Fakültesi Arkeoloji ve Sanat Tarihi Bölümü Protohistorya ve Önasya Arkeolojisi Anabilim Dah ōğretim üyesi

1 Bu çalışma İstanbul Üniversitesi Araşurma Fonunca desteklenmiştir: Proje No 935/ 090597

${ }^{2}$ Bu dōnem kazı çalışmalarına heyet üyesi olarak Arş.Gör. Şevket Dōnmez ile İstanbul Üniversitesi stajyer lisans öğrencileri Burhan Gülkan, Alunay K.Erdem, Nalan İçōz, Elif Özdursun, Dilek Çavdar, Neval Akyol, Esra Ceylan, Ali Bingōl, Mutlu Dinçer, Aslıhan Yurtsever, Mine Kuzu, Begüm Saluk, Derya Tanış, Ayşe Önder ve Türkan Aktoprak katıldı. Bakanlık uzmanı olarak Samsun Müzesi araşurmacılarından Emine Yılmaz kazıda görev aldı. 
14, D 6-11/I 15 ve D 10/I 16 plankarelerini kapsayan $325 \mathrm{~m}^{2}$.lik bir alanında (Res.2) geliştirilen kazılar sonucunda 1993-1996 dönemlerinde ortaya çıkarılmış olan 6 mimari tabakadan sadece $3,4,5$ ve 6 . Mimari Tabakaların devamı takip edildi. Ayrıca, D 7-11/I 14 ile D 10-11/I 15 plankarelerinde daha da derinleşilerek 5 yeni mimari tabakanın yani $7,8,9$, 10 ve 11 . Mimari Tabakaların varlığı ortaya çıkartıldı.

Bu kazılar sonucunda projenin 1. Aşaması ile ilgili olarak arsenikli bakırdan imal edilmiş 2 zıpkınucu 5. (Şek.049) ve 8. Mimari Tabaka'da (Şek.050), 1 delici (Şek.001) 9. Mimari Tabaka'da, 1 olta iğnesi (Şek.048=Res.36) 7. Mimari Tabaka'da, 1 keski (Şek.024=Res.27), 1 küpe (Şek.163) ile 1 kesici (Şek.020) ise 11. Mimari Tabaka'da ele geçti. Bunlara ek olarak, Tepe I'de erozyon sonucunda ortaya çıkmış olan yine bakır ağırlıklı bir alaşımdan ortası delik 1 disk (Şek.224) bulundu. Ayrıca, maden zanaatı faaliyetlerinin göstergeleri olan ponzadan 3 zımpara 6 . (Şek.240=Res.118) ve 8. Mimari Tabaka'da (Şek.238, 239), 2 bileytaşı ise 7. (Şek.233) ve 8. Mimari Tabaka'da (Şek.231) ele geçti. Toplam 8 adet yeni metal eser ve 5 adet madencilikle ilgili alet (TABLO 1) ele geçmesine rağmen metal eserlerin yapım yerleri olan atölyelere ait izler saptanamadı.

Projenin 2. Aşamasını oluşturan ve İkiztepe kazılarında daha önceki dönemlerde ele geçirilmiş bulunan arsenikli bakır eserlerin ${ }^{3}$ imalinde kullanılmış olan bakır ile arsenik metallerinin yatakları, ergitme ocakları veya atölyelerini saptamak amacıyla Samsun ve Amasya illeri sınırları içinde geliştirilen yüzey araşturması 29 ile 31 Ağustos 1997 tarihleri arasında 3 gün süre ile gerçekleştirildi ${ }^{4} .3$ aşamada gerçekleştirilmesi planlanan yüzey araşturmasının 1. Aşamasında İkiztepe - Kolay - Çakıralan - Ilıca - Havza güzergahı izlenerek Köprübaşı köyüne ulaşıldı (Harita). Buradan Tavşan Dağı'nın (Res.3) kuzeyinde bulunan $5 \mathrm{~km}$ uzunluğundaki Bakırçay vadisinin kuzeye bakan ağzından güneye doğru yaklaşı $1.5 \mathrm{~km}$ uzunluğundaki bir kısmı ince-

${ }^{3}$ Ô.Bilgi: "Metal Objects from İkiztepe-Turkey". Beiträge zur Allgemeinen und Vergleichenden Archäologie 6, Bonn 1984: 31-96; "Metal Objects from İkiztepe-Turkey". Beiträge zur Allgemeinen und Vergleichenden Archäologie 9-10, Bonn 1990: 119-219; “ikiztepe'den Ünik Bir Hançer", Belleten LI, Ankara 1987: 1109-1115; "1974 ile 1986 Kazı Dönemlerinde Bulunan Tunç Silahların Işı̆̆ı Altunda İkiztepe'nin Önasyadaki Yeri”. X. Türk Tarih Kongresi, Ankara 1990 Cilt I: $70-77$

${ }^{4}$ Yüzey araşurmasına heyet üyesi olarak Arş.Gör. Şevket Dönmez ile desinatōr Burhan Gülkan katıldı. Bakanlık temsilcisi olarak Samsun Müzesi araştırmacılarından Emine Yılmaz gōrev aldi. 
lendi (Res.4). Ersandık ve Aşağı Meryemdere köylerinin güneybatısında yer alan vadinin bu kesiminde herhangi bir maden yatağına veya cüruf yığınına rastlanmadı. Fakat, çay yatağında güneyden sel suları ile geldiği anlaşılan dağınık ve az sayıdaki curuflardan analiz için örnekler toplandı.

Yüzey araşturmasının 2. Aşamasında İkiztepe - Bafra - 19 Mayı - Samsun Kavak - Havza - Merzifon - Gümüşhacıköy güzergahı izlenerek Gümüş beldesine gelindi (Harita) ve araşurmalar Gümüş'ün batusında yer alan İnegöl Dağı'nda (Res.5) gerçekleştirildi. İlk olarak Gümüş'ün yaklaşık 5 km kuzeybatısında yer alan Kartalkaya mevkiine ulaşıldı ve burada bulunan kayalıklardaki evvelce saptanmıs bulunan büyüklü küçüklü madenci galerileri görüldü (Res.6). Daha sonra Gümüş'ün $20 \mathrm{~km}$ kuzeybatusında yer alan ve Büyük Alan köyü ile Sallar köyü arasındaki Niyazbaba türbesinden adını alan Niyazbaba mevkii incelendi. Ínceleme sonucunda, türbenin $10 \mathrm{~m}$ batısında ve yolun hemen kenarındaki kayalıklarda bir takım küçük galerilere rastlandı (Res.7). $\mathrm{Bu}$ galerilerin duvarlarında yer alan metalik parıltıların analizlerini yapurmak ve ne olduklarını anlamak için kayalardan örnekler alındı.

Yüzey araşurmasının 3. Aşamasında İkiztepe - Bafra - 19 Mayıs - Samsun Kavak - Havza - Merzifon - Gümüşhacıköy - Osmancık ve Dodurga güzergahı izlendikten sonra Oğuzlar (eski adı Karaveren) ilçesine ulaşıldı (Harita). Araşurmanın bu aşamasında ilçe sakinlerinden civarda maden yatağı ve cüruf kalıntısı bulunup bulunmadığı sorulanına olumsuz cevap alındı.

Projenin 3. Aşamasını daha önceki kazılarda ortaya çıkmış olan eserlerle bölgede olasılıkla üretilmiş olup müsadere, bağış, satınalma yoluyla elde edilmiş metal eserleri saptamak için Samsun ve Sinop Müzeleri ile Samsun'da özel bir koleksiyonda incelemeler yapıldı. Bu çalışmalar sonucunda sayıları toplam 91'i bulan metal eser ile maden zanaat ile ilgili 3 adet buluntu saptandı (TABLO 2).

Metal eserler üzerinde gerçekleştirilen çalışmalar sonucunda Samsun Müzesi'ndeki ${ }^{5} 62$ eserin 18 'i satun alma, 1 adedi bağış, 1 adedi müsadere ve 3 adedi İkiztepe ve Oymağaç'ta yapılmış olan yüzey araşturması yoluyla, 39'u ise bölgede yapılmış bulunan Dündartepe, Tekeköy ve Kaledoruğu kazılarından gelmiş olduğu görüldü ${ }^{6}$ (TABLO 3). Satunalma eserlerin 1 adedi mızrakucu (Şek.133=Res.74), 1 adedi yassı balta (Şek.065), 2 adedi kolcuklu yassı balta

\footnotetext{
${ }^{5}$ Samsun Müzesi'ndeki çalışmalarda her türlü yardımı sağlayan Mūdūr Mustafa Akkaya ile Müze Araşturmacısı Uğur Terzioğlu'na teşekkür ederim.

${ }^{6} \mathrm{Bu}$ kazılarda ele geçipte yayınlanmamıs bulunan metal eserleri incelememe izin veren hocalanm Nimet ve Tahsin Özgüç'e teșekkür ederim.
} 
(Şek.070,083), 6 adedi okucu (Sek.148=Res.84,154,155,159,160,161=Res.89), 4 adedi keski (Şek.030,036=Res.31, 038,041), 2 çifti müzik aleti (Sek.057=Res.40 ve 058=Res.41), 1 adedi yüzük (Şek.172=Res.92) ve 1 adedi de halhaldır (Şek.175). Müsadere olarak sadece 1 kalem (Şek.019) Müze koleksiyonuna girmiştir. Samsun Müzesindeki 4 keskiden 1 adedi bağış (Şek.039), 3 adedi ise İkiztepe (Şek.025,026 ${ }^{7}$ ) ve Oymaağaç'da (Şek.032) yapılan yüzey araşturmalarından gelmiştir. Kazılar sonucunda gelmiş 39 eserin 37 adedi Dündartepe, 1 adedi Tekeköy ve 1 adedi de Kaledoruğu'nda ele geçmiştir. Dündartepe'de bulunmuş eserlerin 2 adedi hançer $\left(\right.$ Sek. $101,102^{8}=$ Res.59), 2 adedi okucu (Sek.1459 $=$ Res.81 ve $149=$ Res.85), 1 adedi yassı balta (Sek.063), 1 adedi kolcuklu yassı balta ${ }^{10}$ (\$̧ek.087), 3 adedi zıpkınucu ( Sek.051=Res.37 ve 052,053), 2 adedi keski ${ }^{11}$ (\$ek.027=Res.28 ve 043), 2 adedi kesici ${ }^{12}$ (Sek.022=Res.25 ve 023=Res.26), 4 adedi delici $\left(\right.$ Şek.004,007,008,009 ${ }^{13}=$ Res.20), 1 adedi tığ $(S$ ek.054), 2 adedi ustura (Şek.045, 046 ${ }^{14}=$ Res.34), 4 adedi dikiş iğnesi (Şek.011,012,014 ${ }^{15}, 015$ ), 9 adedi iğne (Sek.177,181,182,200,205 ${ }^{16}, 206^{17}, 207,222^{18}=$ Res.109 ve $223^{19}=$ Res.110), 2 adedi küpe (Şek.164 ${ }^{20}, 165$ ), 1 adedi yüzük (Şek.170) ve 1 adedi de bileziktir ${ }^{21}$ (Şek.166). Diğer taraftan, Tekeköy'de bulunan tek eser hançer (Şek.100), Kaledoruğu'nda ele geçen ise 1 delicidir (Şek.003). Demir bir okucu (Şek.148=Res.84) ile kurşun bir yüzük dışında (Şek.170) Samsun Müzesi'nde çalışılan eserlerin hepsi bakır ağırlıkı bir alaşımdan imal edilmiştir.

Samsun Müzesi'ndeki madencilikle ilgili 3 eserden biri taştan master model, diğer ikisi ise pt kalıptır. Master model Kaledoruğu'nda

7 Kızıltan, Z. 1992: "Samsun Bölgesi Yüzey Araşurmalanı 1971-1977". Belleten LVI, Ankara: 213-241 Sek.17

${ }^{8}$ Ozgūç 1948: Lev.IV,8

${ }^{9}$ Kökten/Ozgüç/Ózgūç 1945: Lev.LXXI,12

${ }^{10}$ Kökten/Özgüç/Özgŭç 1945: Lev.LXXI,1

${ }^{11}$ Kökten/Ögūç/Özgūç 1945: Lev.LXVI,1 ve Lev.LXXI,2

12 Ozgūç 1948: Lev.I,2 ve Kōkten/Özgüç/Özgüç 1945: Lev.LXXI,4

${ }^{13}$ Kökten/Özgüç/Özgūç 1945: Lev.LXVI,2

${ }^{14}$ Kökten/Özgüç/Özgüç 1945: Lev.LXXI,3

${ }^{15}$ Kökten/Ozgūç/Özgūç 1945: Lev.LXXI,7

${ }^{16}$ Ózgüç 1948: Lev.I,10

${ }^{17}$ Ozgūç 1948: Lev.I,11

${ }^{18}$ Kökten/Ozgūç/Ozgũç 1945: Lev.LXXI,5

${ }^{19}$ Ozgũç 1948: Lev.I,12

${ }^{20}$ Ozgūç 1948: Lev.I,14

${ }^{21}$ Ozgūç 1948: Lev.I, 13 
(Şek.227=Res.115), kalıplardan birincisi Vezirköprü-Gölköy ${ }^{22}$ (Şek.226=Res.112), ikincisi Bafra-Tedigüntepe'de (Şek.225=Res.111) ele geçmiştir.

Sinop Müzesi'nde ${ }^{23}$ çalışılan 28 eserin 25 adedi satınalma ve 1 adedi bağıs yoluyla ve 2 adedi de Sinop'ta yapılmıs bir kazı sonucunda müzeye gelmiştir (TABLO 3). Hepsi bakır ağırlıklı bir alaşımdan imal edilmiş olan bu eserlerin satın alma grubunun 5 adedi mizrakucu (Şek.115=Res.68 ve 121,122,123,125), 4 adedi kargıucu (Şek.138,141 $1^{24}, 142,143$ ), 4 adedi hançer (S.ek.106=Res.61, 107=Res.62, 108=Res.63 ve 109= Res.64), 1 adedi yassı balta (Şek.060), 4 adedi kolcuklu yassı balta (Şek.069,076,077,080), 1 adedi sap delikli balta (Şek.096=Res.56), 2 adedi kalem (Şek.016,017), 1 adedi ustura ${ }^{25}$ (Şek.047=Res.35), 1 adedi delici (Şek.006) ve 2 adedi de keskidir (Şek.029,037). Bunlara ek olarak yine bakır ağırlıklı bir alaşımdan yapılmış 1 adet kargıucu (Şek.139) bağış yoluyla, 1 adet mızrakucu (Şek.120=Res.69) ile 1 adet iğne ise (Şek.178) Sinop Kız Öğretmen Okulu bahçesinde yapılan kazı sonucunda müzeye gelmiştir.

Diğer taraftan, Samsun Tofaş Anabayi-Samoto Otomobil Ticaret A.Ş. Müdürü Yurdagün Gülümser'in firma bünyesinde toplamış bulunduğu özel kolleksiyondaki eserler gözden geçirildi. Bu eserler arasındaki nerede bulunduğu belli olmayan bakır ağırlıklı bir alaşımdan yapılmıs mızrakucunun (Şek.127) araşturma projesi ile ilgili olduğu anlaşılde ${ }^{26}$.

Müze ve özel koleksiyonlarda gerçekleştirilen çalışmalarla İkiztepe'de 1997 dönemi kazılarında ele geçirilen toplam 99 metal eser işlevlerine göre gruplandığında 17 eserin takı, 39 eserin silah ve 43 eserin de alet sınıfina ait olduğu gözlendi. Takı sınıfına giren eserlerin yüzük, küpe, iğne, halhal, bileziklerden oluştuğu görüldü. Sap delikli balta, kolcuklu balta, yassı balta, hançer, okucu, mızrakucu ve kargıuçlarının silahlar grubunu ve kalem, ustura, uğ, olta iğnesi, keski, kesici, dikiş iğnesi, delici ve çalparaların da aletler sınıfını oluşturduğu saptandı (TABLO 4). Bu 99 metal eserin 8 adeti İTÇ II,

${ }^{22}$ Altanatolisches Metallhandwerk, Neumünster 1994: 205 Taf.36,1 A.Müller-Karpe

${ }^{23}$ Sinop Müzesi'ndeki çalışmalarda her türlü yardımı sağlayan Müdür İsmail Tatlıcan ile Müze Araşurmacısı Fuat Dereli'ye teşekkür ederim.

${ }^{24}$ Işın 1998: P1.28

${ }^{25}$ Işı̀n 1998: P1.28

${ }^{26}$ Özel koleksiyonunu incelememe açan ve söz konusu eseri burada yayınlamama izin ve ren Yurdagün Gülümser'e teşekkür ederim. 
23 adeti İTÇ III, 55 adeti OTÇ, 5 adeti GTÇ, 7 adeti GDÇ'na ve 1 adeti de HÇ'a aittir (TABLO 5). Proje kapsamında biraraya getirilen 99 metal eser ile madencilik zanaatunda kullanılmış olduğu düşünülen 8 adet buluntunun 13 adeti İkiztepe kazısından, 93 adeti de Samsun ve Sinop Müzelerinden ve 1 adeti de özel koleksiyondan elde edildi (TABLO 6).

\section{DÖNEMI ÇALIŞMALARI}

1998 yllında geliştirilen İkinci Proje ${ }^{27}$ ile ilgili çalışmalar yine 3 aşamalı olarak 03.07.1998 ile 05.09.1998 tarihleri arasında gerçekleştirildi.

1998 projesinin 1. Aşamasını oluşturan İkiztepe örenyerindeki kazı çalışmaları 03 Temmuz - 31 Ağustos 1998 tarihleri arasında 60 gün süre ile geliştirildi ${ }^{28}$. Tepe III'te (Res.1) yer alan "L" açmasının D 7-11/I 14 plankarelerini (Res.2) kapsayan $125 \mathrm{~m}^{2}$.lik bir alanında geliştirilen kazılar sonucunda 1993-1997 dönemlerinde ortaya çıkarılmış bulunan 11 mimari tabakadan sadece 9, 10 ve 11. Mimari Tabakaların devamı takip edildi. Ayrıca, D 10-11/I 14 plankarelerinde daha da derinleşilerek 8 yeni mimari tabakanın, yani 12 , $13,14,15,16,17,18$ ve 19. Mimari Tabakaların varlıkları ortaya çıkarıldı.

Bu çalışmalar sonucunda projenin 1. Aşaması ile ilgili olarak arsenikli bakırdan imal edilmiş 1 yüzük (Şek.169) 11. Mimari Tabaka'da, 1 delici (Şek.002) 15. Mimari Tabaka'da ve 1 tel parçası (Şek.055) 17. Mimari Tabaka'da ele geçti. Bunlara ek olarak 12. Mimari Tabaka içinde ortaya çıkan ve üst yapı katının, yani 11. Mimari Tabaka'nın mezarına ait olduğu anlaşılan iskeletin (Res.8) her bir ayağında, arsenikli bakırdan yapılmış birer halhal (Şek.173 ve $174=$ Res.93) ile mezar toprağı içinde gümüş (?) 1 yüzük (Şek.168) bulundu. Ayrıca, maden zanaatı faaliyetinin göstergesi sayılabilecek olan ponzataşından 1 zımpara (Şek.241) 14. Mimari Tabaka'da ve pt bir pota (Şek.228=Res.113) 12. Mimari Tabaka'da ele geçti. Toplam 6 adet yeni metal eser ve 2 adet madencilikle ilgili alet ele geçmesine rağmen metal eserlerin yapım yerleri olan atölyeler hala saptanamadı. Diğer taraftan, 12,

27 Bu çalışma İstanbul Üniversitesi Araşurma Fonunca desteklenmiştir: Proje No $1083 / 010598$

${ }^{28} \mathrm{Bu}$ dōnem kazı çalışmalarına heyet üyesi olarak Arş. Gör. Şevket Dönmez, desinatör-arkeolog Burhan Gülkan ile İstanbul Üniversitesi stajyer lisans öğrencileri Esra Ceylan, Ali Bingöl, Begüm Saluk, Derya Tanış, Ayşe Önder, Murat Türkteki, Demet Türkmen, Işıl Kayı, Pınar Bayar, Umut Turunçoğlu, Nergis İper ve Gülbin Söğütlüoğlu kauldı. Bakanlık uzmanı olarak Samsun Müzesi araşurmacılarından Şükran Atalar kazıda görev aldı. 
13 ve 14. Mimari Tabakalarda ele geçen bakır filizi cüruf parçaları ile 13 ve 14. Mimari Tabakalarda ortaya çıkarılan ve 2 evreli olduğu saptanan firın kalıntılarından alınan cüruflar analizleri yapılmak üzere Boğaziçi Üniversitesi Kimya Bölümü laboratuvarına verildi.

Projenin 2. Aşamasını oluşturan ve İkiztepe'de ele geçirilmiş bulunan arsenikli bakır eserlerin imalinde kullanılmış olan bakır ile arsenik metallerinin yatakları, ergitme ocakları veya atölyelerini saptamak amacıyla Samsun, Amasya ve Tokat illeri sınırları içinde geliştirilen yüzey araştırmaları 3 ile 10 Ağustos 1998 tarihleri arasında 8 gün süre ile gerçekleştirildi ${ }^{29}$.

4 aşamalı olarak planlanan 1998 dönemi yüzey araşurmasının 1. Aşamasında İkiztepe - Bafra - 19 Mayıs - Samsun - Kavak - Havza - Merzifon - Derealan köyü güzergahı izlenerek Tavşan dağındaki Bakırçay vadisinin güney ağzından girilerek vadinin batı yamaçları incelendi (Harita). İnceleme sonucunda Derealan köyünün $3 \mathrm{~km}$ kadar kuzeyinde 5 ayrı yerde curuf kalıntuları saptandı. Bu curufların bir yığınt şeklinde olmayıp oldukça yayılmış bulundukları gözlendi. Bunlardan analiz için örnekler toplandı. Daha sonra Bakırçay'ın 3 km kadar kuzeybatısında, Bakırçay'a paralel olarak akan ve kuzeyde Köprübaşı köyü yakınlarında Bakırçay'la birleşen Peynirçayı vadisinin bat yamaçları incelendi. Bu yamaçlardan Bakacak Tepesi olarak adlandırılan kesimde yer alan Pırasakaya mevkiinde (Res.9) görülen maden yataklarının görünüşe göre arsenik cevheri içeren filizlere (arsenopirit=Res.10) sahip olduğu düşünüldü. Bu hususta kesin sonucun ancak filizlerden analiz için alınan örneklerin laboratuvar değerlendirmesi sonrasında anlaşılacağı aşikardır.

Yüzey araștırmasının 2. Aşamasında Merzifon - Alıcık - Gümüşhacıköy Gümüş - Çayköy ve Gölköy güzergahı izlendikten sonra Hamamözü ilçesine ulaşıldı (Harita). Araştırmanın bu aşamasında ilçe sakinlerinden civarda maden yatağı veya cüruf kalıntısı bulunup bulunmadığı sorularına olumsuz cevaplar alındı.

Yüzey araşurmasının 3. Aşamasında yine Merzifon - Gümüşhacıköy güzergahı izlenerek Gümüş Beldesi'ne gelindi (Harita). Buradaki araşturmalar

${ }^{29}$ Yüzey araşurmasına heyet üyesi olarak Prof.Dr. Hadi Özbal, Arş.Gör. Şevket Dōnmez, yüksek lisans ōğrencisi desinatör-arkeolog Burhan Gülkan ile stajyer lisans öğrencisi Murat Türkteki katuldı. Bakanlık temsilcisi olarak da İstanbul Arkeoloji Müzeleri araşturmacılarından Ali Önder araşurmada gōrev aldı. 
Gümüş Beldesi'nin batısında yer alan İnegöl Dağı'nda gerçekleştirildi. 1997 yllında tarafimızdan incelenmiş olan Niyazbaba mevkiine tekrar gidildi ve daha geniş bir alan araşturıldı. Daha sonra Gümüş'ün $4 \mathrm{~km}$ güneybatısında yer alan Karaali köyünün batısındaki Karlıdoruk Tepesi'ne ulaşıldı (Res.11) ve burada bulunan birtakım galerilerdeki maden filizlerinden analiz için parçalar alınd..

Yüzey araşturmasının 4. Aşamasında ise, İkiztepe - Bafra - 19 Mayıs - Samsun - Kavak - Ladik güzergahı izlenerek Taşova'ya gelindi (Harita). Taşova civarında yer alan Teneke ve Akınoğlu (eski Tekke) köylerinde incelemeler yapıldıktan sonra Erbaa yakınlarındaki, İlk Tunç Çağı'na ait önemli maden eserleri ile tanınan Horoztepe yerleşimi incelendi. Daha sonra maden galerileri ve cüruf kalıntıları ile bilinen Kozlu'ya gidilmek istendi. Ancak bölgenin kırsal kesiminde yaşanmakta olan terör olayları nedeniyle bu yörenin araşt rılmasından şimdilik vazgeçildi.

Sonuç olarak, taranan bölge içinde yüzey araşturmamızın amacına yönelik sonuçlara, ancak toplanan örneklerin analizinden sonra varılabileceği ortaya çıktı.

Projenin 3. Aşamasını daha önceki kazılarda ortaya çıkan eserlerle olasılıkla Orta Karadeniz Bölgesi'nde üretilmiş olup satınalma, müsadere yada bağış yoluyla elde edilmiş metal eserleri saptamak için Samsun, Sinop, Kastamonu, Amasya ve Tokat Müzelerinde incelemeler yapıldı. Bu çalışmalarda toplamı 107 adeti bulan metal eser daha saptand.

Samsun Müzesi'nde ${ }^{30}$ çalışılan 4 eserin de satunalma yoluyla gelmiş olduğu ve hepsinin mızrakucu türünde silah olup, olasılıkla arsenikli bakırdan imal edilmiş bulunduğu gözlendi (Şek.113=Res.67, 114, 126=Res.70, 130).

Sinop Müzesi'nde çalışılan 30 eserin 29 adedinin satın alma, 1 adedinin ise bağış yoluyla Müze'ye kazandırılmış bulunduğu anlaşıldı. Hepsi bakır ağırlıklı bir alaşımdan yapılmış olan satınalma eserlerin 28 adedi iğne (Şek.180,183,184 ${ }^{31}, 185,186=$ Res.95, 187, 188,189 ${ }^{32}, 190=$ Res.96, 191=Res.97, $196=$ Res.99, 197, 198=Res.100, 199, 208=Res.104, 209,210,211,212,213, 214,215, 216=Res.105, 217,218, 219=Res.106, $220^{33}=$ Res.107, 221=Res.108), 1

\footnotetext{
${ }^{30}$ Bu dōnem çalışmalarında da yardımlarını esirgemeyen Müdür Mustafa Akkaya ile Müze Araşturmacısı Uğur Terzioğlu'na teșekkür ederim.

${ }^{31}$ Işın 1998: Pl.28

32 Ișın 1998: Pl.28

${ }^{33}$ Işın 1998: Pl.28
} 
adedi de dikiş iğnesidir (Şek.013=Res.22). Bu eserlerin Gerze-Hıdırlı köyü yakınındaki bir mezarlıktan yasa dışı kazılar sonucunda elde edilerek Müze'ye satıldığı belirtilmiştir. Bağış eser ise, başına disk biçiminde siyah bir taş takılmış ve demirden imal edilmiş bir iğnedir (Şek.204=Res.103).

Amasya Müzesi'nde ${ }^{34}$ incelenen 65 adet eserin 54 adedi satunalma ve 11 adedi ise bağış yoluyla gelmiştir. Satın alma eserlerin 1 adedi kesici ${ }^{35}$ (Şek.021=Res.24), 2 adedi delici (Şek.005=Res.19 ve 010=Res.21), 6 adedi keski (Sek.031=Res.29, 033 ${ }^{36}=$ Res.30, 034 ${ }^{37}, 035,040,042=$ Res.32), 1 adedi kalem (Şek.018=Res.23), 8 adedi mızrakucu (Şek.116 $6^{38}, 117^{39}, 118,119$, $128=$ Res.71, 132=Res.73, 134=Res.75, 136=Res.77), 1 adedi kargiucu ${ }^{40}$ (Şek.137=Res.78), 6 adedi hançer (Şek.099, 103=Res.60, 104 ${ }^{41}, 105$, $110=$ Res.65, 111=Res.66), 2 adedi yassı balta (Şek.061 $\left.{ }^{42}, 062\right), 12$ adedi kolcuklu balta (Şek.067=Res.44, 068,073,074,075, 078, 079=Res.47, 081, 082, 085, 086=Res.49, 088), 7 adedi sap delikli balta (Şek.089 $9^{43}=$ Res.50, 090= Res.51, 091 ${ }^{44}=$ Res.52, $093^{45}=$ Res.54, 094 ${ }^{46}, 095=$ Res.55, 097=Res.57) ve 8 adedi de iğnedir (Şek.179,192,193, 194=Res.98, 195,201, 202=Res.101, 203=Res.102). Demir 1 mızrakucu dışında (Şek.136=Res.77) satun alma eserlerin hepsi bakır ağırlıklı bir alaşımdan imal edilmiştir. Bağış yoluyla Müze'ye gelmiş eserlerin 10 adedi Gümüşhacıköy'ün İmirler köyü yakınlarında yasa dışı kazılar sonucunda tahrip edilmiş ve atıyla birlikte gömülmüş bir süvariye ait mezardan (kurgandan) çıkmadır ${ }^{47}$. Bunlar demirden 1 kılıç

34 Amasya Müzesi'ndeki çalışmalarda her türlü yardımı sağlayan Müdür Ahmet Yüce ile Müze Araşturmacısı Celal Ōzdemir'e teşekkür ederim.

${ }^{35}$ Daha önce yayımlanmıştur. bkz. Özgüç 1978: Şek.80 Lev.68,5

${ }^{36}$ Daha önce yayımlanmışur. bkz. Özgüç 1978: Lev.69,3

${ }^{37}$ Daha önce yayımlanmıştur. bkz. Özgüç 1978: Lev.69,6

38 Daha önce yayımlanmışur. bkz. Özgüç 1978: Şek.81 Lev.68,4

${ }^{39}$ Daha önce yayımlanmışur. bkz. Özgüç 1978: Șek.76 Lev.68,3

${ }^{40}$ Daha önce yayımlanmışur. bkz. Özgüç 1978: Şek.83

${ }^{41}$ Daha önce yaymlanmışur. bkz. Ö.Bilgi: "Some Unstratified Metal Weapons from the East Anatolian Museums". Between The Rivers and Over The Mountains, Roma 1993: 601-604 Fig.1

${ }^{42}$ Daha önce yayımlanmıştr. bkz. Özgüç 1978: Lev.69,4

43 Daha önce yayımlanmışur. bkz. Özgüç 1978: Sek.87 Lev.70,1

${ }^{44}$ Daha önce yaymmlanmışur. bkz. Özgüç 1978: \$̧ek.89 Lev.70,2

${ }^{45}$ Daha önce yayımlanmıştur. bkz. Özgüç 1978: Şek.90 Lev.70,3

${ }^{46}$ Daha önce yayımlanmışur. bkz. Özgüç 1978: Lev.70,5

${ }^{47} \mathrm{Bu} 10$ metal eser dışında yine yasa dışı kazılar sonucunda elde edilmiş olup müzeye müsadere yoluyla gelmiş okuçları bu çalışma kapsamına alınmadı. Aynca, bu bölgedeki Taşova-Ladik'de yer aldığı sooylenilen tahrip olmuş ikinci bir mezarda ele geçmiş okuçları da yine bu çalışmaya dahil edilmedi. bkz. V.Ûnal: Zwei Gräber eurasischer Reiternomaden im nördlichen Zentralanatolien". Beiträge zur Allgemeinen und Vergleichenden Archäoloschie 4, Bonn 1982: $65-81$ 
(Şek.162=Res.90), demir ve kalaylı bakırdan yapılmış 1 kazma-balta ile bunun kabzesi (Şek.098=Res.58), yine kalaylı bakırdan 1 gem (Şek.056=Res.39) ve 7 adet okucudur (Şek.150, 151=Res.86, 152,153,156, 157=Res.87, 158=Res.88). Bağıs yoluyla gelmiş diğer eser ise kalaylı bakırdan yapılma diğer bir okucudur (Şek.147=Res.83).

Tokat Müzesi'nde ${ }^{48}$ incelenen 7 eserden 5 adedi satın alma, 1 adedi müsadere ve 1 adedi ise kazı yoluyla gelmiştir. Satun alma yoluyla gelmiş eserlerin 1 adedi mızrakucu (Şek.135=Res.76), 1 adedi kargıucu (Şek.140=Res.79), 1 adedi okucu (Şek.146= Res.82), 1 adedi kolcuklu balta (Şek.084=Res.48) ve 1 adedi de keskidir (Şek.044= Res.33). Kazı yoluyla gelmiş eser Turhal-Ulutepe'de bulunmuş olan 1 bileziktir (Şek.167=Res.91). Müsadere yoluyla gelmiş eser ise 1 mühürdür (Şek.059=Res.38). Tokat Müzesi'nde incelenen eserlerin hepsi bakır ağırlıklı alaşımlardan imal edilmiştir.

Kastamonu Müzesi'nde yanlızca 1 mızrakucu incelendi (Şek.129). Büyük olasılıkla arsenikli bakırdan imal edilmiş mızrakucunun Samsun-Dündartepe kazısından gelmiş olduğu envanter kayıtlarından anlaşıldı.

Müzelerde gerçekleştirilen çalışmalarla İkiztepe'de 1998 dönemi kazılarında ele geçirilenlerle birlikte toplam 113 metal eser işlevlerine göre gruplandığında 42 eserin takı, 55 eserin silah ve 16 eserin de alet sınıfına ait olduğu gözlendi. Takı grubuna giren eserlerin yüzük, iğne, halhal ve bileziklerden oluştuğu görüldü. Silahlar grubunun ise sap delikli, kolcuklu, yassı balta ile kazma-balta, hançer, okucu, mızrakucu, kargıucu, kılıçtan oluştuğu ve gem, mühür, keski, kesici, dikiş iğnesi, delici gibi eserlerin de aletler grubunu oluşturduğu saptandı.

1998 yılı araşurmalarında toplanan bu eserlerin geçici olarak tarihlenmeleri yapıldığında; 6 adedinin İTÇ II'ye, 28 adedinin ITCÇ III'e, 57 adedinin OTÇ'na, 11 adedinin GTÇ'na ve 11 adedinin de GDÇ'na ait olduğu görünmektedir (TABLO 7). İTÇ II'ye ait eserleri alet (delici, tel) ve takı (yüzük, halhal), İTÇ III'e ait eserleri silah (mızrakucu, kargıucu, hançer, yassı balta, sap delikli balta), alet (kesici, keski) ve takı (bilezik), OTÇ’na ait eserleri silah (mızrakucu, hançer, kargıucu, okucu, kolcuklu balta, sap delikli balta), alet (keski, delici, dikiş iğnesi, mühür) ve takı (iğne), GTÇ'na ait eserleri silah (hançer, kolcuklu balta, sap delikli balta) ve GDÇ'na ait eserleri ise silah (kılıç, kazma-balta, okucu) ve aletlerin (gem) oluşturduğu görüldü (TABLO 8 ve TABLO 9).

\footnotetext{
${ }^{48}$ Tokat Müzesi'ndeki çalışmalarda her türlü yardımı sağlayan Müdür Birsen Özcan'a teşekkür ederim.
} 


\section{DÖNEMİ ÇALIŞMALARI}

1999 ylında geliştirilen Üçüncü Proje ${ }^{49}$ ile ilgili çalışmalar yine 3 aşamalı olarak 12.07.1999 ile 25.09.1999 tarihleri arasında gerçekleştirildi.

1999 dönemi projesinin 1. Aşamasını oluşturan İkiztepe örenyerindeki kazı çalışmaları 19 Temmuz - 27 Ağustos 1999 tarihleri arasında 40 gün süre ile gerçekleştirildi ${ }^{50}$. Tepe III'te (Res.1) yer alan "L" açmasının D 6, 7, 8 ve 9/I 12 ve 13, D 10/I 13, D 8/I 16 ve 17 ve D 9/I 16 plankarelerini (Res.2) kapsayan $300 \mathrm{~m}^{2}$.lik bir alanında geliştirilen kazılar sonucunda 1993-1998 dönemlerinde ortaya çıkarılmış bulunan 19 mimari tabakadan sadece 1, 2, 3, 4,5 ve 6 . Mimari Tabakaların devamı takip edildi.

Bu çalışmalar sonucunda projenin 1. Aşaması ile ilgili olarak arsenikli bakırdan imal edilmiş 1 yüzük (Şek.171) ile başlı 1 iğne (Şek.176=Res.94) 3. Mimari Tabaka'da ve 1 okucu (Şek.144=Res.80) 5. Mimari Tabaka'da ele geçti.

Diğer taraftan, maden zanaatı faaliyetinin göstergesi sayılabilecek olan 5 adet bileytaşı 1. (Şek.235=Res.117), 3. (Şek.237), 4. (Şek.232=Res.116 ve 234) ve 6. Mimari Tabakalarda (Şek.236) ve birisi kırık (Şek.229), diğeri kavrulmuş (Şek.230=Res.114) 2 pota 5. Mimari Tabaka'da bulundu. Toplam 3 adet yeni metal eser ile 7 adet madencilikle ilgili aletlerin yanısıra metal eserlerin yapım yerleri olan atölyelere örnek olabilecek bir firın kompleksi de ortaya çıkaruldı.

D 8/I 13 (b.3605) ile D 9/I 13 (b.3602) plankarelerinin bitiştiği kesimde b. 3607 olarak kodlanan $1.50 \times 1.40 \mathrm{~m}$ boyutundaki dikdörtgen planlı firının, mevcut genişliği $55 \mathrm{~cm}$ olan ağzı güneybattya bakar (Res.12). Ortalama duvar kalınlığı $15 \mathrm{~cm}$ olan fırının güney ve güneydoğu duvarlarının yıkık olduğu gözlendi. Fırının kuzey duvarının ağzına yakın tarafında, zeminden yüksekliği $30 \mathrm{~cm}$, çapı $4 \mathrm{~cm}$ olan ve firın duvarının dışından içine doğru uzanan iyi sıvalı boşluğun bir körük deliği olduğu görüldü. Fırının çok iyi sı050599

${ }^{49}$ Bu çalışma İstanbul Üniversitesi Araşturma Fonunca desteklenmiştir: Proje No 1250/

${ }^{50}$ Bu dönem kazı çalışmalarına heyet üyesi olarak Arş.Gör. Şevket Dönmez, desinatör ar keolog Burhan Gülkan, arkeolog Hilal Kömbe ve antropolog Nuran Salar ile İstanbul Üniversitesi stajyer lisans ōğrencileri Murat Türkteki, Işıl Kayı, Pınar Onataslan, Peyman Saygınōz, İpek Bilgi, Faruk Demirci, Nergis İper ve Gülbin Söğütüoğlu katıldı. Bakanlık uzmanı olarak Niğde Müzesi araşurmacılarından Mahmut Altuncan kazıda görev aldı. 
vanmış 3 katlı sert tabanı doğudan batuya doğru $15 \mathrm{~cm}$ kot farkı yapar. Fırının ağzına bitişik olarak yapılmış $75 \times 70 \mathrm{~cm}$ boyutunda yuvarlağımsı ve iyi sıvanmış bir işlik vardır. Ayrıca, firının biri kuzeybatısında, diğeri ise kuzeydoğusunda olmak üzere 2 adet bağımsız işliğinin (Res.13) daha bulunduğu görüldü. Kuzeybatudaki dikdörtgen biçimli işlik $1.90 \times 0.90 \mathrm{~m}$ boyutundadır. Tabandan yüksekliği $20 \mathrm{~cm}$ olan bu işliğin iyi sıvanmış sert tabanı kuzeydoğudan güneybatuya doğru $5 \mathrm{~cm}$ kot farkı yapar. Bu tabanın içe göçmüş olarak bulunmasından ilk yapıldığında altunda ahşap bir konstrüksiyonun yer aldığı varsayılabilir ve tabanın orijinalinde ahşap bir kasnak üzerine oturtulmuş olduğu kenarlarının altunda ortaya çıkan boşluklardan anlaşıldı. Kuzeydoğudaki işlik ise gayrimuntazam yarım daire biçimlidir. Tabandan yüksekliği 15 $\mathrm{cm}$ olan işlik düzgün bir kil sıvaya sahiptir. Bir kompleks görünümündeki firının kuzeyinde ve işliklerin arasında yaklaşı $1 \mathrm{~m}$ uzunluğunda $14 \mathrm{~cm}$ derinliğinde ve bir depo görünümünde iyi sıvalı bir mekanın varlığı da gözlendi. b.3607 olarak kodlanmış firın yapısal açıdan ayrıntılı bir şekilde incelendiğinde, zemininde dikdörtgen şeklinde, boyutu $1.70 \times 1.30 \mathrm{~m}$ ve kalınlığı 15 $\mathrm{cm}$ olan ahșap bir kasnak inşa edilmiş olduğu ve bu kasnağın $20 \mathrm{~cm}$ kalınlığında bir kil tabakası ile yükseltilmiş bulunduğu anlaşıldı. Ahşap ve kil konstrüksiyonla oluşturulmuş olan bu yükseltinin $2 \mathrm{~cm}$ kalınlığındaki bir sıva ile düzgün bir platform haline getirildikten sonra, mevcut yüksekliği $30 \mathrm{~cm}$ olarak saptanan kubbesinin oluşturulmasında kullanılmış olan $2 \mathrm{~cm}$ çapındaki (yaş ?) ve belirli aralıklardaki ağaç dallarının bırakmış olduğu boşluklar saptandı. Bu boşluklardan kuzey duvarı üzerinde 5 , güney duvarı üzerinde ise 4 adet bulundu. Fırın tabanının 2 kat sıvanmıs olduğu gözlendi. Bunlardan birincisi 2, ikincisi ise $3 \mathrm{~cm}$ kalınlığındadır.

Fırının kuzeybatısında bulunan dikdörtgen planlı işliğin inşa edilmiş olduğu zeminde, firında olduğu gibi dikdörtgen şeklinde $1.80 \times 0.80 \mathrm{~m}$ boyutunda ve $10 \mathrm{~cm}$ genişliğindeki ahşaptan bir kasnak oluşturulmuş olduğu görüldü. Bu kasnağın üstünün $20 \mathrm{~cm}$ kalınlığında kil ile kaplanarak yükseltildiği ve bu yükseltinin de $3 \mathrm{~cm}$ kalınlığındaki kil bir sıva ile düzgün bir hale getirildiği anlaşıldı.

Fırının kuzeydoğusunda yer alan işliğin, firının doğusunu çevreleyen kil sıva üzerine inşa edilmiş olduğu görüldü. Uzun kenarları altuna $10 \mathrm{~cm}$ genişliğinde 7 adet paralel hatulın yerleştirilmiş olduğu ve bunların üzerinin 15 $\mathrm{cm}$ kalınlığında kil bir dolgu ile yükseltilmiş olduğu gözlendi. Bu dolgunun üzerinin ise birinci kat 5, ikinci kat 2, üçüncü kat 3, dördüncü kat 2 ve beşinci kat $3 \mathrm{~cm}$ kalınlığındaki 5 kat sıvaya sahip olduğu saptandı. 
Fırının ağzına bitişik olarak yapılmış olan küçük işliğin zemininin de kuzeybatl-güneydoğu yönlerinde yerleştirilmiş ve birbirine bitişik durumda, 10 $\mathrm{cm}$ kalınlığındaki, en uzunu $50 \mathrm{~cm}$ ve en kısası ise $30 \mathrm{~cm}$ olan, sayıları $5^{\prime} \mathrm{i}$ bulan ahşap hatullarla döşenmiş olduğu, bu hatulların üzerinin de $15 \mathrm{~cm}$ kalınlığındaki bir kil tabakası ile yükseltilmiş bulunduğu gözlendi. Bu yükseltinin de $3 \mathrm{~cm}$ kalınlığındaki kil bir sıva ile düzgün bir hale getirilmiş olduğu görüldü.

Projenin 2. Aşamasını oluşturan ve İkiztepe'de ele geçirilmiş bulunan eserlerin imalinde kullanılmıs olan bakır ile arsenik metallerinin yatakları, ergitme ocakları veya atölyelerini saptamak amacıyla 1998 yılında Samsun, Amasya ve Tokat illerinin sınırları içinde geliştirilen yüzey araştırmaları sonucunda Bakırçay'ın 3 km kadar kuzeybatısında, Bakırçay'a paralel olarak akan ve kuzeyde Köprübaşı köyü yakınlarında Bakırçay'la birleşen Peynirçayı vadisinin batı yamaçlarındaki Bakacak Tepesi olarak adlandırılan kesimde yer alan Pırasakaya mevkiindeki (Res.9) arsenik cevher filiz yatağı (arsenopirit türü=Res.10) ile Sinop-Durağan ilçesi yakınındaki Gökdoğan köyü sınırları içinde yer alan, Durağan-Alaçam yolu üzerindeki Çayağzı veya Ağuboğazı mevkiinde (Harita) ve hemen Kızılırmak Nehri kenarında (Res.14, 15 ve 16) saptanmıs bulunan arsenik cevher filiz yatağı (realgar=Res.17 ve orpiment=Res.18 türleri) incelendi.

Sonuç olarak, 1997 yllından beri yoğun olarak taranan bölge içinde ve yukarıda belirtilen yerlerden toplanan örneklerin analiz sonuçlarından sonra araşurmaların başarıya ulaştığı ve İkiztepelilerin bakırın yanısıra arseniği de Tavşan Dağından ve yine arseniği Durağan yakınlarından elde etmiş oldukları açıkça anlaşıldı ${ }^{51}$. Diğer taraftan, Roma dönemi tarihçisi Amasyalı Strabon'un Coğrafya ${ }^{52}$ kitabında bahsetmiş bulunduğu arsenik cevherlerinin yerlerinin bu bölgeyi de kapsadığı, daha doğrusu bu bölgeyi kastettiği ortaya çıkmıştur.

Projenin 3. Aşamasını, olasılıkla Orta Karadeniz Bölgesi'nde üretilmiş olup satınalma, müsadere ya da bağıs yoluyla elde edilmiş metal eserleri saptamak için Samsun ve Sinop Müzelerinde uzmanlarla görüşmeler yapıldı. Bu

${ }^{51}$ bkz. "Samsun-Amasya-Tokat Illleri Yüzey Araşurması". XV. Arkeometri Sonuçlan Toplanusı, Ankara 2000: 47-54 (24 - 28 Mayss 1999) H.Özbal/A.Adriaens/ B.Earl/B.Gedik Kültür Bakanlığı Yayını

${ }^{52}$ bkz. Coğrafya, Anadolu Kitap XII, İstanbul 1987 Strabon (Çeviren A. Pekman) Arkeoloji ve Sanat Yayınlan 
görüşmeler sonucunda söz konusu müzelere yeni eserler gelmediği, ancak Samsun Müzesi kontrolu altundaki özel koleksiyoncularda proje kapsamına giren metal eserler bulunduğu saptandı.

Samsun'da oluşturulmuş bulunan bu özel koleksiyonlardan birincisi Yurdagün Gülümser'e aittir. Bu koleksiyonda bakır ağırlıklı bir alaşımdan yapılmış 6 silah ve 1 alet üzerinde çalışıldı ${ }^{53}$. Silahlardan 2 adeti İTÇ III'e ait mızrakucu (Şek.112 ve 131=Res.72), 2 adeti OTÇ’na ait yassı balta (Şek.064=Res.42 ve 066=Res.43) ve biri OTÇ'na (Şek.072=Res.46), diğeri GTÇ'na (Şek.071=Res.45) ait 2 adet kolcuklu baltadır. Tek alet ise İTÇ III'e ait bir keskidir (Şek.028). İkinci koleksiyon Tayfun Lay'a ${ }^{54}$ ait olup yine bakır ağırlıklı bir alaşımdan yapılmış ve İTÇ III'e tarihlenen bir mızrakucu (Șek.124) ile sap delikli bir baltadır (Şek.092=Res.53).

Proje kapsamında İkiztepe kazısında ve özel koleksiyonlardan biraraya getirilen 12 adet metal eser ile maden zanaat ile ilgili olduğu düşünülen 7 adet buluntunun 3 adeti İTÇ II, 12 adeti İTÇ III ve 4 adeti de OTÇ'na aittir (TABLO 10).

\section{GENEL DEĞERLENDİRME}

Orta Karadeniz Bölgesi'nde Protohistorik Çağ'da, yani İÖ 4500 ile İÖ 500 yılları arasını kapsayan yaklaşık 4000 yllık bir zaman süreci içinde maden sanatunın ortaya çıkışı ile nasıl bir gelişim gösterdiğinin ayrıntıları ile araşturılması ve bu bölge maden sanatının Anadolu maden sanatıdaki yeri ile komşu ülkelerin çağdaş kültürlerinin maden sanatlarıyla ilişkilerinin ortaya konmasına yönelik 1997 - 1999 yılları arasını kapsayan 3 yıl süreli proje ${ }^{55}$ çerçevesinde İkiztepe örenyerinde geliştirilen kazılarda 17 adet metal eser ile 14 adet madencilik zanaat ile ilgili alet, Samsun, Sinop, Amasya, Tokat ve

${ }^{53} 1997$ yılındaki incelememden sonra özel koleksiyonuna yeni katmış olduğu bu eserleri de burada yayınlamama izin veren Yurdagün Gülümser'e bir kez daha teșekkür ederim.

${ }^{54}$ Özel koleksiyonundaki eserleri görmeme ve burada ikisini yayınlamama izin veren Tayfun Lay'a teșekkür ederim.

${ }^{55}$ Araşurma projesinin gerçekleşmesinde büyük katkılanı bulunan başta yardımcı araşturıcı Dr. Sevket Dönmez olmak üzere heyet üyeleri ile araşturma izinlerini sağlayan Kültür Bakanlı̆ı Anıtlar ve Müzeler Genel Müdürlüğü'ne, gerekli alt yapı desteği ve izinleri sağlayan İstanbul Üniversitesi Edebiyat Fakültesi Dekanlı̆ğ'na, bürokratik işlemlerde yardımcı olan Bafra Kaymakamlı̆̆ı'na ve ellerinden gelen her türlü yardımı esirgemeyen Samsun Müzesi Müdürlüğü'ne içten teşekkürlerimi sunarım. Ayrıca, bu araşturmanın yayına hazırlanmasında büyük emeği geçen Dr. Şevket Dönmez ile desinatör-arkeolog Burhan Gülkan'a içten teşekkür etmeyi bir borç bilirim. 
Kastamonu Müzelerindeki incelemelerde 197 adet metal eser ile 3 adet madencilik zanaat ile ilgili alet ve özel koleksiyonlarda 10 adet metal eser saptandı. Toplamı 241 olan bu eserlerin 224 adeti metal eser ve 17 adedi de madencilik zanaatu ile ilgili alettir (TABLO 11 ve TABLO 18).

Toplam 224 metal eserin 219 adeti bakır veya bakır ağırlıklı bir alaşımdan (büyük olasılıkla arsenikli bakır), 1 adeti gümüş ve 4 adeti de demirden yapılmıştur. Gümüş olan küpe (Şek.168) İTÇ II'ye ve 4 adet demir eserden iğne olanı OTÇ'na (Şek.204) ve kılıç, okucu ve mızrakucu olanları da GDÇ'na (Şek.162,148,136) aittir.

224 metal eserin 14 adeti İTÇ II'ye, 57 adeti İTÇ III'e, 118 adeti OTÇ'na, 16 adeti GTÇ'na, 18 adeti GDÇ'na ve 1 adeti de HÇ'a aittir (TABLO 11).

224 metal eserin 60 adeti alet, 103 adeti silah ve 61 adeti de takıdır (TABLO 11).

60 adet aletin (TABLO 12) 10 adeti delici (Şek.001-010), 5 adeti dikiş iğnesi (Şek.011-015), 4 adeti kalem (Şek.016-019), 4 adeti kesici (Şek.020023), 21 adeti keski (Şek.024-044), 3 adeti ustura (Şek.045-047), 1 adeti olta iğnesi (Şek.048), 5 adedi zıpkınucu (Şek.049-053), 1 adeti tuğ (Şek.054), 1 adeti tel (Şek.055), 1 adeti gem (Şek.056), 2 çift çalpara (Şek.057-058), 1 adeti mühür (Şek.059) ve 1 adeti de disktir (Şek.224).

103 adet silahın (TABLO 14) 39 adeti balta (Şek.060-098), 13 adeti hançer (Şek.099-111), 25 adeti mızrakucu (Şek.112-136), 7 adeti kargıucu (Şek.137-143), 18 adeti okucu (Şek.144-161) ve 1 adeti de kılıçtur (Şek.162).

39 adet baltanın (TABLO 17) 7 adeti yassı (Şek.060-066), 22 adeti kolcuklu (Şek.067-088), 9 adeti sap delikli (Şek.089-097) ve 1 adeti de kazma balta (Şek.098) türündedir.

13 adet hançerin (TABLO 16) 6 adeti saplı (Şek.099-104), 4 adeti perçin delikli (Şek.105-108) ve 3 adeti de kabzelidir (Şek.109-111).

25 adet mizrakucunun (TABLO 15) 3 adeti saph (Şek.112-114), 11 adeti bağ delikli (Şek.115-125), 7 adeti boğumlu (Şek.126-132), 1 adeti teber ağızlı (Şek.133) ve 3 adeti de kovanlı (Şek.134-136) türündedir.

7 adet kargıucunun 1 adedi saplı (Şek.137) ve 6 adeti de kovanlı (Şek.138-143) türündedir.

18 adet okucunun 5 adeti iğneli (Şek.144-148), 4 adeti kovanlı (Şek.149152), 6 adeti mahmuzlu (Şek.153-158) ve 3 adeti de 3 yaprakh namlulu (Şek.159-161) türündedir. 
61 adet takının (TABLO 13) 3 adeti küpe (Şek.163-165), 2 adeti bilezik (Şek.166-167), 5 adeti yüzük (Şek.168-172), 3 adeti halhal (Şek.173-175) ve 48 adeti de iğnedir (Şek.176-223).

48 adet iğne baş biçimlerine göre 12 grupta toplanır (TABLO 18): Damla başlı (Şek.177), Küre başlılar (Şek.178-181,183-186,188-190,192196,218), Yarım küre başlı (Şek.182), Basık küre başlı (Şek.187,217,221), Yassı başlı (Şek.206), Çift küre başlı (Şek.202), Mantar başlılar (Şek.191,201,216), Piramit başlılar (Şek.176,209-215), Küp başlı (Şek.205), Altugen başlı (Şek.207), Haşhaş başı (Şek.203), Yassı haşhaş başhı (Şek.222), Dilimli küre başılıar (Şek.197-200,219), Dilimli yassı başı (Şek.220), Disk başlı (Şek.204), Ters koni başı (Şek.208), Kıvrık başlı (Şek.223). Bazı iğnelerde baş alunda ip deliği (Şek.209-223) bazılarında ise metal (Şek.194) veya kemik boncuk (Şek.221) yer alır. Disk başı iğnenin başı siyah renk bir taştan, gövdesi de demirdendir.

17 adet madencilik zanaat ile ilgili aletin (TABLO 19) 2 adeti pt kalıp (Şek.225-226), 1 adeti taş master model (Şek.227), 3 adeti pt pota (Şek.228230), 7 adeti bileytaşı (Şek.231-237) ve 4 adeti de ponza zımparadır (Şek.238-241).

Sonuç olarak, bu proje çerçevesindeki araşurma sonucunda biraraya getirilen maden sanat ile ilgili eserlerin İTÇ II'den HÇ'a kadar 2700 yıllık geniş bir döneme ait silah, alet, takı örnekleri olduklan ve bunların daha önce bu bölgede bulunanlara katılması ile Orta Karadeniz Bölgesi'nin Anadolu madencilik sanatının gelişiminde rol oynamış bulunduğu özellikle SinopDurağan'daki zengin arsenik ve Merzifon-Bakırçay'daki bakır ve arsenik cevheri yataklarına sahip olmasından açıkça belli olmaktadır. 


\section{KISALTMALAR}

$\begin{array}{ll}\text { Ağ } & \text { Ağırlı } \\ \text { GDÇ } & \text { Geç Demir Çağı } \\ \text { GTÇ } & \text { Geç Tunç Çă̆ı } \\ \text { HÇ } & \text { Helenistik Çağ } \\ \text { Işın, M.A. } & \\ 1998 & \text { "Sinop Region Field Survey". Anatolia Antiqua VI, Paris: 95- } \\ & \text { 139 } \\ \text { İTÇ } & \text { İlk Tunç Çă̆ı } \\ \text { Kökten, K./Özgü, N./Özgüç, T. } \\ \text { 1945 } & \text { "1940-1941 Yllında Türk Tarih Kurumu Adına Yapılan Sam- } \\ & \text { sun Bölgesi Kazıları Hakkında Ilk Kısa Rapor". Belleten IX, } \\ \text { M } & \text { Ankara: 361-400 } \\ \text { OTÇ } & \text { Müzesi } \\ \text { Özgüç, T. } & \text { Orta Tunç Çağı } \\ 1948 & \text { "Samsun Hafriyatının 1941-1942 Yılı Neticeleri". III. Türk } \\ & \text { Tarih Kongresi, Ankara: 393-419 } \\ 1978 & \text { Maşat Höyük Kazıları ve Çevresindeki Araştırmalar, Ankara }\end{array}$





\title{
KATALOG
}

\author{
ALETLER \\ DELICI
}

\section{Basit}

İTÇ II

001 97-083: İkiztepe, b.3515; SAMSUN M,kazı Tüm U 5.2 G 0.5 K 0.1 Ağ 2

002 98-130: İkiztepe, b.3569; SAMSUN M,kazı Tüm U 6 Ç 0.3

İTC III

003 4-164/1974: Kaledoruğu; SAMSUN M,kazı Tüm U 9.6 Ç 0.4

OTÇ

004 4-176/1974: Dündartepe; SAMSUN M,kazı Tüm U 6 K 0.3

005 A.79.18.53: ?; AMASYA M,satunalma Tüm U 11.4 Ç 0.4 (Res.19)

006 20-34/75: Hıdırlı Köyü, Gerze; SİNOP M,satunalma Tüm U 8.8 K 0.4

007 4-163/1974: Dündartepe; SAMSUN M,kazı Tüm U 9.2 G 0.6 K 0.3

008 4-185/1974: Dündartepe; SAMSUN M,kazı Tüm U 6.3 Ç 0.4

\section{Boğumlu}

OTC

009 4-157/1974: Dündartepe; SAMSUN M,kazı Tüm U 22.2 G 1.3 K 0.6 (Res.20)

010 A.79.18.29: ?; AMASYA M,satunalma Tüm U 17.1 G 0.9 Ç 0.5 (Res.21)

\section{Díkiş İĞNESI}

\section{OTC}

011 4-187/1974: Dündartepe; SAMSUN M,kazı Gözü kırık U 7.4 Ç 0.2

012 4-188/1974: Dündartepe; SAMSUN M,kazı Tüm U 9.7 Ç 0.2

013 2-3/81: ?; SİNOP M,satunalma Tüm U 8.4 Ç 0.4 (Res.22) 
014 4-189/1974: Dündartepe; SAMSUN M,kazı Tüm U 9.3 Ç 0.3 015 4-190/1974: Dündartepe; SAMSUN M,kazı Tüm U 6.5 Ç 0.3

\section{KALEM}

OTÇ

016 01-1/76: Koçcuağaz Köyü, Sinop; SiNOP M,satunalma Tüm U 8.8 G 1 K 0.5

017 01-2/76: Koçcuağaz Köyü, Sinop; SíNOP M,satunalma Tüm U 8.8 G 0.5 K 0.4

018 A.79.18.28: ?; AMASYA M,satınalma Tüm U 8.5 G 1 K 0.9 (Res.23)

019 8-1/1984: ?; SAMSUN M,müsadere Tüm U 11.9 G 0.9 K 0.9

\section{KESICi}

Tek Sapl

İTÇ II

020 97-097: İkiztepe, b.3526; SAMSUN M,kazı Kırık U 4 G 1.1 K 0.2 Ağ 3 İTÇ III

021 A.71.11.21: ?; AMASYA M,satunalma Tüm U 11.8 G 2.9 K 0.8 (Res.24) OTC

022 4-169/1974: Dündartepe; SAMSUN M,kazı Tüm U 9.2 G 1.4 K 0.2 (Res.25)

İki Saplı

OrC

023 4-173/1974: Dündartepe; SAMSUN M,kazı Tüm Y 5.3 U 11.6 K 0.5 (Res.26)

\section{KESKI}

\section{İnce Uzun Gövdeli}

İTÇ II

024 97-094: İkiztepe, b.3526; SAMSUN M,kazı Tüm U 17.5 G 0.6 K 0.5 Ağ 22 (Res.27) 


\section{İTCุ III}

025 04-21/77: İkiztepe, yüzey; SAMSUN M,kazı Tüm U 16.2 G 1.4 K 0.9 026 04-22/77: İkiztepe, yüzey; SAMSUN M,kazı Tüm U 20.7 G 2.8 K 1.2 OTC

027 4-155/1974: Dündartepe; SAMSUN M,kazı Tüm U 27.3 G 1.2 K 0.9 (Res.28)

\section{Geniş Gövdeli \\ İTC III}

028 Gülümser 56: Samsun; ÖZEL KOLEKSIYON Tüm U 12.9 G 4 K 1.1 029 01-4/75: ?; SINOP M,satunalma Tüm U 12.5 G 3.6 K 1.1 030 08-1/1982: ?; SAMSUN M,satunalma Tüm U 10.8 G 3.2 K 0.8 031 A.79.18.26: ?; AMASYA M,satunalma Tüm U 11.3 G 4.1 K 0.9 (Res.29) 032 09-12/1973: Oymaağaç, Vezirköprü; SAMSUN M,yüzey Kırık U 7 G 1.3 K 0.2

033 A.75.16.13: Harmancık-Göynücek;AMASYA M,satunalma Tüm U 12.5 G 2 K 2 (Res.30)

034 A.75.16.12: Harmancık, Göynücek; AMASYA M,satunalma Tüm U 9.5 G $3.4 \mathrm{~K} 0.9$

035 A.86.2.6: ?; AMASYA M,satunalma Tüm U 11.5 G 2.6 K 1.1

036 11-5/1992: ?; SAMSUN M,satunalma Tüm U 23 G 2.8 K 0.7 (Res.31)

OTC

037 07-12/75: ?; SINNOP M,satunalma Tüm U 6.2 G 1.9 K 0.3 038 11-4/1992 ?; SAMSUN M,satunalma Tüm U 6.2 G 2 K 0.4 039 14-1/1984: ?; SAMSUN M,bağış Tüm U 10.5 G 3.1 K 0.6 040 A.81.10.31: ?; AMASYA M,satunalma Ensesi hasarlı. U 9.1 G $2.6 \mathrm{~K} 1$ 041 9-1/1995: ?; SAMSUN M,satunalma Tüm U 10.4 G 3.4 K 0.4 042 A.79.2.10: ?; AMASYA M,satunalma Tüm U 8.8 G 1.6 K 0.8 (Res.32)

\section{Kovanl}

OTC

043 4-156/1974: Dündartepe; SAMSUN M,kazı Tüm U 13 G 2 K 0.2

044 86.48.1: Zile; TOKAT M,satunalma Tüm U 16.4 G 2.5 K 1.2 (Res.33) 
ÖNDER BILGI

\section{USTURA}

\section{İTC III}

045 4-174/1974: Dündartepe; SAMSUN M,kazı Tüm U 8.4 G 1.4 K 0.1

046 4-172/1974: Dündartepe; SAMSUN M,kazı Tüm U 15.8 G 1.3 K 0.2

(Res.34)

OTC

047 20-33/75: Hıdırlı Köyü, Gerze; SíNOP M,satınalmaTüm U 9.2 G 2.4 K 0.4 (Res.35)

\section{OLTA İĞNESI}

İTÇ II

048 97-071: İkiztepe, b.3511; SAMSUN M,kazı Tüm U 2.7 K 0.3 Ağ 2 (Res.36)

\section{ZIPKINUCU}

İTC II

049 97-032: İkiztepe, b.3506; SAMSUN M,kazı Tüm U 9.3 G 0.5 K 0.4 Ağ 10 050 97-115: İkiztepe, b.3519; SAMSUN M,kazı Tüm U 3.9 G 0.5 K 0.3 Ağ 1.5 İTC III

051 4-158/1974: Dündartepe; SAMSUN M,kazı Tüm U 12.7 K 0.5 (Res.37)

052 4-160/1974: Dündartepe; SAMSUN M,kazı Kırık U 9.5 K 0.5

053 4-159/1974: Dündartepe; SAMSUN M,kazı Tüm U 8.2 K 0.4

TIĞ

\section{İTC III}

054 4-175/1974: Dündartepe; SAMSUN M,kazı Tüm U 11.7 Ç 0.4

TEL

İTC II

055 98-121: İkiztepe, b.3574; SAMSUN M,kazı Tüm U 6.1 Ç 0.4

\section{GEM}

GDC

056 A.71.19.6: İmirler, Gümüşhacıköy; AMASYA M,bağış Tüm U 18.5 G 2.8 K 0.8 (Res.39) 


\section{CQALPARA}

\section{Tutamakh}

İTÇ III

057 13-1/1984: Durağan, Sinop; SAMSUN M,satunalma Tüm Y 7 Ç 10 K 0.3 (Res.40)

\section{İp Delikli}

\section{GTC}

058 12-2/1970: ?; SAMSUN M,satunalma Tüm Ç 4.6 K 0.2 (Res.41)

\section{MŪHŪ̃R}

OTÇ

059 82.11.1: Turhal; TOKAT M,bağış Tüm Y 2.7 Ç 2 K 0.8 (Res.38)

\section{SIILAHILAR \\ BALTALAR \\ YASSI}

\section{İTÇ III}

060 4-1/74: ?: SiNOP M,satunalma Tüm U 17.3 G 4.4 K 1.5

061 A.75.20.4: Merzifon; AMASYA M,satunalma Tüm U 14.4 G 4.4 K 1.7 062 A.97.1.1: Amasya; AMASYA M,satınalma Tüm U 17 G 4.6 K 1.1

OTC

063 4-166/1974: Dündartepe; SAMSUN M,kazı Tüm U 14.6 G 2.4 K 0.5

064 Gülümser 89: Samsun; ÖZEL KOLEKSIYON Tüm U 15.3 G 4.5 K 0.7 (Res.42)

065 11-3/1992: ?; SAMSUN M,satunalma Tüm U 21 G 5.6 K 2.2

066 Gülümser 90: Samsun; ÖZEL KOLEKSIYYON Tüm U 8.4 G 5.7 K 1.2 (Res.43)

\section{KOLCUKLU}

\section{Basit}

OTÇ

067 A.75.20.3: Merzifon; AMASYA M,satunalma Tüm U 18.2 G 4.4 K 1.2 (Res.44) 
068 A.72.6.2: ?; AMASYA M,satunalma Tüm U 14.5 G 4.2 K 1.3

069 26-7/76: Erfelek, Sinop; SINNOP M,satunalma Tüm U 9.8 G 4.5 K 0.8

070 11-1/1992: ?; SAMSUN M,satunalma Tüm U 12 G 5.5 K 0.7

071 Gülümser 91: Samsun; ÖZEL KOLEKSIYYN Tüm U 13 G 5 K 0.6 (Res.45)

072 Gülümser 55: Samsun; ÖZEL KOLEKSIYYON Ensesi kırık U 14.5 G 3.6 K 0.9 (Res.46)

\section{GTÇ}

073 A.96.17.1: Tuzsuz köyü; AMASYA M,satınalma Ağzı kırık. U 17.4 G 9 K 0.9

074 A.73.23.22: ?; AMASYA M,satunalma Tüm U 13.6 G 6.2 K 0.7

075 A.73.23.23: ?; AMASYA M,satunalma Tüm U 12.8 G 3.8 K 0.9

076 15-1/83: Bülbül Köyü, Sinop; SINOP M,satınalma Tüm U 8.2 G 3.9 K 0.6

077 10-1/88:Dibekli Köyü, Sinop; SINNOP M,satunalma Tüm U 18.8 G 7 K 1.3

078 A.96.18.1: Esençay Köyü, Taşova; AMASYA M,satınalma Tüm U 15.1 G $7.2 \mathrm{~K} 0.9$

079 A.75.5.1: Göynücek; AMASYA M,satınalma Tüm U 14.5 G 6 K 1.1

(Res.47)

080 4-1/81: Erfelek, Sinop; SINOP M,satınalma Tüm U 16.7 G 6.4 K 1.4

081 A.73.23.21: ?; AMASYA M,satunalma Tüm U 14.6 G 5.5 K 1.1

082 A.90.2.2: ?; AMASYA M,satunalma Tüm U 14.8 G 5.7 K 0.8

083 11-2/1992: ?; SAMSUN M,satunalma Tüm U 14.7 G 5.7 K 0.8

084 84.25.1: Tokat; TOKAT M,satunalma Tüm U 10.1 G 5.3 K 0.7 (Res.48)

085 A.79.11.40: ?; AMASYA M,satunalma Tüm U 16.3 G 5.5 K 1

\section{İp Delikli}

\section{OTC}

086 A.83.10.5: ?; AMASYA M,satunalma Tüm U 15 G 3.6 K 1.2 (Res.49)

087 4-165/1974: Dündartepe; SAMSUN M,kazı Tüm U 13.2 G 3.6 K 1.3

088 A.79.11.41: ?; AMASYA M,satunalma Tüm U 8 G 2.9 K 1 


\section{SAP DELİKL亡}

\section{İTÇ III}

089 A.74.11.1: Taşova; AMASYA M,satunalma Tüm U 13.9 G 3 K 1.7 (Res.50) 090 A.78.6.2: ?; AMASYA M,satunalma Tüm U 15 G 2.7 K 2.3 (Res.51) 091 A.74.10.1: Merzifon; AMASYA M,satınalma Ensesi kırık. U 7.7 G $3.1 \mathrm{~K}$ 2.9 (Res.52)

092 Lay 2: Samsun; ÖZEL KOLEKSIYON Tüm U 10.3 G 6.4 K 3 (Res.53) 093 A.73.23.24: ?; AMASYA M,satunalma Tüm U 10.4 Y 5.1 K 2.3 (Res.54) OTC 094 A.75.20.5: Merzifon; AMASYA M,saunalma Tüm U 10. G 4.7 K 2.6 095 A.77.8.1: Harmancık-Göynücek;AMASYA M,satınalmaTüm U 11.7 G 3.7 K 2.8 (Res.55)

096 4-2/81: Erfelek; SiNOP M,satunalma Kırık U 14.4 G 5 K 3.5 (Res.56) GTC 097 A.97.2.3: ?; AMASYA M,satunalma Tüm U 13.9 Y 5.3 K 3.6 (Res.57)

\section{KAZMA BALTA}

GDC

098 A.71.19.5 ve A.71.19.7: İmirler, Gümüşhacıköy; AMASYA M,bağış Tüm U 28.2 Y 9.7 G 2.8 ve U 11.3 G 2.2 K 0.3 (Res.58)

\section{HANÇERLER}

\section{Saph}

İTC III

099 A.79.18.27: ?; AMASYA M,satunalma Tüm U 10.2 G 2.5 K 0.4 100 4-168/1974: Tekeköy Mezarlığı; SAMSUN M,kazı Tüm U 15.5 G 2.7 K 0.4 OTÇ 101 4-170/1974: Dündartepe; SAMSUN M,kazı Tüm U 11.9 G 2 K 0.2 102 4-171/1974: Dündartepe; SAMSUN M,kazı Tüm U 11.1 G 2.3 K 0.4 (Res.59) 103 A.83.10.6: ?; AMASYA M,satunalma Tüm U 18.2 G 4.2 K 0.6 (Res.60) 104 A.88.4.11: ?; AMASYA M,satunalma Tüm U 25.4 G 5.9 K 1.1 
ÖNDER BILGI

\section{Perçin Delikli}

İTC III

105 A.71.11.20: AMASYA M,satunalma Kırık U 10.1 G 1.8 K 0.4

106 17-1/82: Lala Köyü, Sinop; SİNOP M,satınalma Tüm U 22.6 G 2.7 K 0.2 (Res.61)

OTC

107 2-4/73: Hıdırlı Köyü, Gerze; SİNOP M,satunalma Tüm U 18.3 G 5.4 K 0.4 (Res.62)

108 19-30/74: Hıdırlı Köyü, Gerze; SiNOP M,satınalma Tüm U 21 G 4.5 K 0.6 (Res.63)

\section{Kabzeli}

OTC

109 06-4/71: ?; SİNOP M,satunalma Tüm U 25 G 3.4 K 0.4 (Res.64)

110 A.72.6.3: ?; AMASYA M,satunalma Kabzenin ucu kırık. U 19.8 G 3.7 K 0.4 (Res.65)

\section{GIC}

111 A.93.1.1:?; AMASYA M,satunalma Tüm U 36.5 G 9.2 K 1 (Res.66)

\section{MIZRAKUCLARI}

Saph

İTÇ III

112 Gülümser 92: Samsun; ÖZEL KOLEKSIYON Tüm U 20.5 G 3.4 K 0.7

113 1-1/1998: Cedit Mah, Samsun; SAMSUN M,satunalma Tüm U 37.5 G 4.4 K 1.1 (Res.67)

114 1-2/1998: Cedit Mah, Samsun; SAMSUN M,satunalma Tüm U 37 G 4.3 K 1.1

\section{Bă̆ Delikli}

İTC III

115 06-2/71: ?; SiNOP M Tüm U 38.4 G 6.8 K 1.3 (Res.68) 
116 A.71.11.18: ?; AMASYA M,satunalma Kırık U 31.8 G 5.4 K 0.7

117 A.71.11.19: ?; AMASYA M,satunalma Tüm U 19.5 G 4.3 K 0.9

118 A.78.5.2: ?; AMASYA M,satunalma Tüm U 19 G 3.9 K 0.7

119 A.96.13.1: Suluova; AMASYA M,satunalma Ucu kırık. U 20.9 G 5.3 K 0.9

OTC

120 06-3/71: ?; SiNOP M Tüm U 28.1 G 4.7 K 1 (Res.69)

121 2-3/73: Hıdırlı Köyü, Gerze; SiNOP M,satunalma Tüm U 19.7 G 4 K 0.5

122 2-2/73: Hıdırlı Köyü, Gerze; SiNOP M,satunalma Tüm U 17.2 G 3.4 K

0.3

123 11-1/70: Kız Öğretmen Okulu Sinop SíNOP M Tüm U 25.1 G 4.5 K 0.7

124 Lay 1: Samsun; ÖZEL KOLEKSIYON Tüm U 24.5 G 4.7 K 0.5

125 07-1/81: Lala Köyü, Sinop; SíNOP M,satunalma Tüm U 17.2 G 3.1 K 0.6

\section{Boğumlu}

ITCC III

126 01-1/1997: Hıdırellez, Bafra; SAMSUN M,satunalma Tüm U 21.2 G 3.6 K 1.4 (Res.70)

127 Gülümser 42: ?; ÖZEL KOLEKSIYON Tüm U 37.7 G 3.5 K 1.5

128 A.84.2.1: ?; AMASYA M,satunalma Tüm U 37 G 3.8 K 2 (Res.71)

129 Ark.870: Dündartepe; KASTAMONU M,kazı Tüm U 26.4 G 3.2 K 1.9

130 07-1/1997: ?; SAMSUN M,satunalma Tüm U 36.2 G 2.4 K 1.2

131 Gülümser 54: Samsun; ÖZEL KOLEKSIYYON Tüm U 47.5 G 3 K 1.2

(Res.72)

132 A.78.25.3: ?; AMASYA M,satunalma Ucu kırık. U 27.8 G 3.9 K 1.9

(Res.73)

Teber Ağızlı

ITC III

133 01-1/1995: Karayonca-Terme; SAMSUN M,satunalma Tüm U 19.4 G 2.5

K 1 (Res.74) 


\section{Kovanl}

OTC

134 A.97.15.7: Kavak; AMASYA M,satunalma Kovanı ezilmiş. U 38.5 G $3.2 \mathrm{~K}$ 1.9 (Res.75)

135 82.20.1: Zile; TOKAT M,satunalma Tüm U 15.8 G 2.3 K 0.5 (Res.76) GDC

136 A.76.1.9: Taşova;AMASYA M,satunalma Kovan ağzı hasarlı. U 39.5 G 4.9 K 1.1 (Res.77)

\section{KARGIUCU}

\section{Saph}

İTC III

137 A.71.11.17: ?; AMASYA M,satunalma Tüm U 40 G 1.2 K 1.1 (Res.78)

\section{Kovanl}

OTC

138 19-32/74: Hıdırlı Köyü, Gerze; SíNOP M,satınalma Tüm U 15 G 1.6 K 0.4

139 03-5/71: Sinop; SiNOP M,bağış Tüm U 14.1 G 2.1 K 1.2

140 82.20.2: Zile; TOKAT M,satunalma Tüm U 19.5 G 2 K 0.7 (Res.79)

141 20-24/75: Hıdırlı Köyü, Gerze; SİNOP M,satunalma Tüm U 16.7 G 2.4 K 1.2

142 19-31/74: Hıdırlı Köyü, Gerze; SiNOP M,satunalma Tüm U 19.7 G 2.7 K 1.3

143 2-1/73: Hıdırl Köyü, Gerze; SiNOP M,satunalma Tüm U 36.7 G 2.2 K 1.5

\section{OKUCU}

İ̆neli

İTÇ III

144 99-042: İkiztepe, b.3607; SAMSUN M,kazı Tüm U 7.5 G 2.6 K 0.3 (Res.80) 
OTC

145 4-162/1974 : Dündartepe, SAMSUN M,kazı Tüm U 4.3 G 2 K 0.3

(Res.81)

146 84.20.19: Zile; TOKAT M,satunalma Tüm U 9.9 G 1.6 K 0.3 (Res.82)

147 A.74.31.62: ?; AMASYA M,bağış Tüm U 9.7 G 1.3 K 0.3 (Res.83)

GDC

148 10-14/1992: ?; SAMSUN M,satunalma Tüm U 6.8 G 1.3 K 0.6 (Res.84)

\section{Kovanl}

OTC

149 4-161/1974: Dündartepe; SAMSUN M,kazı Tüm U 6.7 G 0.9 K 0.9

(Res.85)

\section{GDC}

150 A.71.20.2: İmirler, Gümüşhacıköy; AMASYA M,bağış Tüm U 3.9 G 1.1 K 0.5

151 A.71.20.1: İmirler, Gümüşhacıköy; AMASYA M,bağıs Tüm U 4.2 G 1.2 K 0.5 (Res.86)

152 A.71.20.3: İmirler, Gümüşhacıköy; AMASYA M,bağıs Tüm U 3.8 G 1.1 K 0.6

\section{Mahmuzlu}

GDC

153 A.71.20.6: İmirler, Gümüşhacıköy; AMASYA M,bağış Tüm U 4.2 G 1.2 K 0.7

154 10-12/1992: ?; SAMSUN M,satunalma TümU 4.1 G 1.3 K 0.7

155 10-13/1992: ?; SAMSUN M,satunalma Tüm U 4 G 1 K 0.5

156 A.71.20.4: İmirler, Gümüşhacıköy; AMASYA M,bağış Tüm U 4.1 G 1.2 K 0.5

157 A.71.20.7: İmirler, Gümüşhacıköy; AMASYA M,bağış Tüm U 4 G 1.1 K 0.5 (Res.87)

158 A.71.20.5: İmirler, Gümüşhacıköy; AMASYA M,bağış Tüm U 4.9 G 1.2 K 0.7 (Res.88) 
Üç Yaprakh Namlulu

GDC

159 10-9/1992: ?; SAMSUN M,satunalma Tüm U 3.1 G 1 K 0.5

160 10-10/1992: ?; SAMSUN M,satunalma Tüm U 3.2 G 1.3 K 0.6

161 10-11/1992: ?; SAMSUN M,satunalma Tüm U 3.7 G 1.3 K 0.5 (Res.89)

\section{KIIIC}

GDC

162 A.71.19.4: İmirler, Gümüşhacıköy; AMASYA M,bağış Tüm U 78.8 G 6.7 K 0.8 (Res.90)

\section{TAKIILAR}

KŪPE

\section{İTC II}

163 97-133: İkiztepe, b.3523; SAMSUN M,kazı Tüm Ç 1 K 0.3 Ağ 1.5 İTÇ III

164 4-195/1974: Dündartepe; SAMSUN M,kazı Tüm Ç 3 K 0.3

165 4-193/1974: Dündartepe; SAMSUN M,kazı Tüm Ç 2.1 K 0.3

\section{BİEZIK}

\section{İTCุ III}

166 4-196/1974: Dündartepe; SAMSUN M,kazı Tüm Ç 4.7 K 0.4

167 76.76.128: Ulutepe, Turhal; TOKAT M,kazı Tüm U 14.5 G 5.7 Ç 0.4 (Res.91)

\section{YÜZŪKK}

\section{İTÇ II}

168 98-058: İkiztepe, b.3560; SAMSUN M,kazı Tüm Ç 1.2 K 0.2 169 98-084: İkiztepe, b.3557; SAMSUN M,kazı Tüm Ç 2.5 K 0.6 İTC III 170 4-194/1974: Dündartepe; SAMSUN M,kazı Tüm Ç 1.9 K 0.4 171 99-023: İkiztepe, b.3618; SAMSUN M,kazı Tüm Ç 2.3 K 0.3 


\section{GDC}

172 3-6/1971: Adatepe Köyü, Vezirköprü; SAMSUN M,satınalma Tüm Ç 1.9 K 0.2 (Res.92)

\section{HALHAL}

\section{İÇ II}

173 98-053: İkiztepe, b.3560; SAMSUN M,kazı Tüm Ç 10.6 K 1.2 (Res.93)

174 98-054: İkiztepe, b.3560; SAMSUN M,kazı Tüm Ç 10.9 K 1.4

175 11-7/1992: ?; SAMSUN M,satınalma Tüm Ç 8.8 K 0.5

\section{İTC III}

İĞNE

176 99-014: İkiztepe, b.3603; SAMSUN M,kazı Tüm U 6.9 C 1.1 (Res.94) OTC

177 4-184/1974: Dündartepe; SAMSUN M,kazı Tüm U 8.3 Ç 0.5

178 11-2/70: Kız Öğretmen Okulu, Sinop; SíNOP M,kazı Tüm U 10.1 Ç 0.2

179 A.79.18.38: ?; AMASYA M,satunalma Tüm U 9.5 C 0.3

180 20-23/75: Hıdırlı Köyü, Gerze; SíNOP M,satınalma Tüm U 5.3 Ç 0.2 G 0.6

181 4-182/1974: Dündartepe; SAMSUN M,kazı Tüm U 8.4 Ç 0.8

182 4-183/1974: Dündartepe; SAMSUN M,kazı Tüm U 5.8 Ç 0.5

183 20-18/75: Hıdırlı Köyü, Gerze; SİNOP M,satınalma Tüm U 11.1 Ç 0.5 G 1.3

184 19-37/74 : Hıdırlı Köyü, Gerze; SINNOP M,satınalma Tüm U 11.1 Ç 0.6 G 1.1

185 20-16/75: Hıdırlı Köyü, Gerze; SİNOP M,saunalma Tüm U 16.5 Ç 0.6 G 1.4

186 02-10/73: Hıdırlı Köyü, Gerze; SíNOP M,satunalma Tüm U 16 Ç 0.7 G 1.7 (Res.95)

187 02-16/73: Hıdırı Köyü, Gerze; SiNOP M,satınalma Tüm U 10.9 Ç 0.3 G 1.3

188 20-17/75: Hıdırlı Köyü, Gerze; SiNOP M,saunalma Tüm U 10.9 Ç 0.5 G 1.4 
189 20-14/75: Hıdırlı Köyü, Gerze; SiNOP M,satınalma Tüm U 26.8 Ç 0.6 G 2.2

190 02-11/73: Hıdırlı Köyü, Gerze; SİNOP M,satunalma Tüm U 15.4 Cุ 0.5 G 1.4 (Res.96)

191 20-15/75: Hıdırlı Köyü, Gerze; SíNOP M,satınalma Tüm U 15.1 Ç 0.6 G 2.1 (Res.97)

192 A.71.11.23: ?; AMASYA M,satunalma Tüm U 11.3 G 0.9 Ç 0.3

193 A.77.23.2: Terziköy; AMASYA M,satunalma Tüm U 6.1 G 1.5 Ç 0.3

194 A.79.18.35: ?; AMASYA M,satunalma Tüm U 11.8 Ç 0.4 (Res.98)

195 A.79.18.31: ?; AMASYA M,satınalma Tüm U 12.6 Ç 0.3

196 19-39/74: Hıdırlı Köyü, Gerze; SİNOP M,satınalma Tüm U 9.4 Ç 0.3 G 0.8 (Res.99)

197 20-22/75: Hıdırlı Köyü, Gerze; SiNOP M,satınalma Kırık U 7.7 Ç 0.5 G 1.1

198 02-21/73: Hıdırlı Köyü, Gerze; SiNOP M,satınalma Kırık U 8.1 Ç 0.3 G 0.8 (Res.100)

199 02-18/73: Hıdırlı Köyü, Gerze; SíNOP M,satınalma Tüm U 8.7 Ç 0.3 G 0.9

200 4-177/1974: Dündartepe; SAMSUN M,kazı Tüm U 6.8 Ç 1.2 201 A.79.18.30: ?; AMASYA M,satunalma Tüm U 14.9 Ç0.4 202 A.79.18.52: ?; AMASYA M,satunalma Tüm U 11.6 Ç 0.4 (Res.101) 203 A.79.18.50: ?; AMASYA M,satunalma Tüm U 8.9 Ç 0.3 (Res.102) 204 01-2/74: ?; SİNOP M,bağıs Tüm U 11.4 K 0.4 G 2.2 (Res.103) 205 4-181/1974: Dündartepe; SAMSUN M,kazı Tüm U 9.7 Ç 0.7 206 4-186/1974: Dündartepe; SAMSUN M,kazı Tüm U 8.2 Ç 0.6 207 4-180/1974: Dündartepe; SAMSUN M,kazı Kırı U 5.8 Ç 1.1 208 02-26/73: Hıdırlı Köyü, Gerze; SiNOP M,satınalma Kırık U 4.9 Ç 0.5 G 1.3 (Res.104)

İp Delikli

OTC

209 19-38/74: Hıdırı Köyü, Gerze; SiNOP M,satınalma Tüm U 9.5 Ç 0.3 G 0.9

210 20-20/75: Hıdırlı Köyü, Gerze; SiNOP M,satınalma Tüm U 10 Ç 0.3 G 0.8 
211 02-13/73: Hıdırlı Köyü, Gerze; SiNOP M,satunalma Tüm U 12.2 Ç 0.5 G 1.2

212 02-9/73: Hıdırlı Köyü, Gerze; SiNNOP M,satınalma Tüm U 13.9 Ç 0.3 G 1.1

213 02-15/73: Hıdırlı Köyü, Gerze; SiNOP M,satınalma Tüm U 11.3 Ç 0.4 G 0.8

214 02-20/73: Hıdırlı Köyü, Gerze; SiNOP M,satunalma Tüm U 10.1 Ç 0.3 G 0.9

215 20-21/75: Hıdırlı Köyü, Gerze; SiNNOP M,satınalma Tüm U 9.8 Ç 0.3 G 0.8

216 02-8/73: Hıdırı Köyü, Gerze; SiNOP M,satınalma Tüm U 13.8 Ç 0.5 G 1.6 (Res.105)

217 02-12/73: Hıdırlı Köyü, Gerze; SiNOP M,satınalma Tüm U 12.5 Ç 0.5 G 1.6

218 02-14/73: Hıdırlı Köyü, Gerze; SiNOP M,satunalma Tüm U 11.7 Ç 0.5 G 1.6

219 02-19/73: Hıdırlı Köyü, Gerze; SiNNOP M,satınalma Tüm U 8.4 Ç 0.4 G 1 (Res.106)

220 20-19/75: Hıdırlı Köyü, Gerze; SiNOP M,satınalma Tüm U 12.3 Ç 0.5 G 1.1 (Res.107)

221 02-17/73: Hıdırlı Köyü, Gerze; SİNOP M,satınalma Tüm U 10.9 Ç 0.4 G 1 (Res.108)

222 4-191/1974: Dündartepe; SAMSUN M,kazı Tüm U 12.2 Ç 0.3 (Res.109)

223 4-192/1974: Dündartepe; SAMSUN M,kazı Tüm U 10.1 Ç 0.3 (Res.110)

\section{DísK}

\section{HELENISTIK ÇAĞ}

224 97-038: İkiztepe, Yüzey; SAMSUN M,kazı Tüm Ç 5.4 K 1.2 Ağ 42 


\section{MADENCILIKKLE ILGIII ALET}

\section{KALIP}

\section{OTC}

225 01-15/93: Tedigüntepe, Bafra; SAMSUN M,yüzey Kırık U 5.1 G 5.2 K 4.5 (Res.111)

226 07-12/73: Gölköy, Vezirköprü; SAMSUN M,satunalma Tüm U 14.2 G 6 Y 4.4 (Res.112)

\section{MASTER MODEL}

İTÇ III

227 4-211/1974: Kaledoruğu; SAMSUN M,kazı Tüm U 16 G 3.2 K 1.7 (Res.115)

\section{POTA}

\section{İTC II}

228 98-033: İkiztepe, b.3558; SAMSUN M,kazı Tüm Y 6.3 G 5.9 K 1.8 (Res.113)

229 99-201: İkiztepe, b.3637; SAMSUN M,kazı Kavrulmuş Y 7.1 G 7.8 K 1.1 230 99-176: İkiztepe, b.3632; SAMSUN M,kazı Kırık U 6.4 G 4.6 K 1.1 (Res.114)

\section{BIIEYTAŞI}

Íp Delikli

İTC II

231 97-123: İkiztepe, b.3521; SAMSUN M,kazı Kırık U 5.5 G 1.5 K 0.9 232 99-122: İkiztepe, b.3622; SAMSUN M,kazı Parça U 6.4 G 1.9 K 1 (Res.116)

233 97-106: İkiztepe, b.3516; SAMSUN M,kazı Kırık U 5.2 G 2.5 K 0.9 İTC III

234 99-044: İkiztepe, b.3609; SAMSUN M,kazı Kırık U 8.6 G 2.6 K 1.2 


\section{Basit}

İTÇ III

235 99-034: İkiztepe, b.3607; SAMSUN M,kazı Kırık U 23.5 G 2.6 K 1.9 (Res.117)

236 99-065: İkiztepe, b.3613; SAMSUN M,kazı Parça U 6.3 G 2.8 K 1.7

237 99-041: İkiztepe, b.3607; SAMSUN M,kazı Kırık U 13.2 G 3.5 K 1.9

\section{ZIMPARA}

\section{İTÇ II}

238 97-126: İkiztepe, b.3521; SAMSUN M,kazı Tüm Y 7 G 6.7 K 4.2

239 97-129: İkiztepe, b.3521; SAMSUN M,kazı Tüm Y 7.9 G 5.1 K 3.3

240 97-066: İkiztepe, b.3509; SAMSUN M,kazı Tüm Y 7.5 Ç 4.6 K 3.6 (Res.118)

241 98-085: İkiztepe, b.3568; SAMSUN M,kazı Tüm Y 7.7 G 6.1 K 3.8 

Önder Bilgi
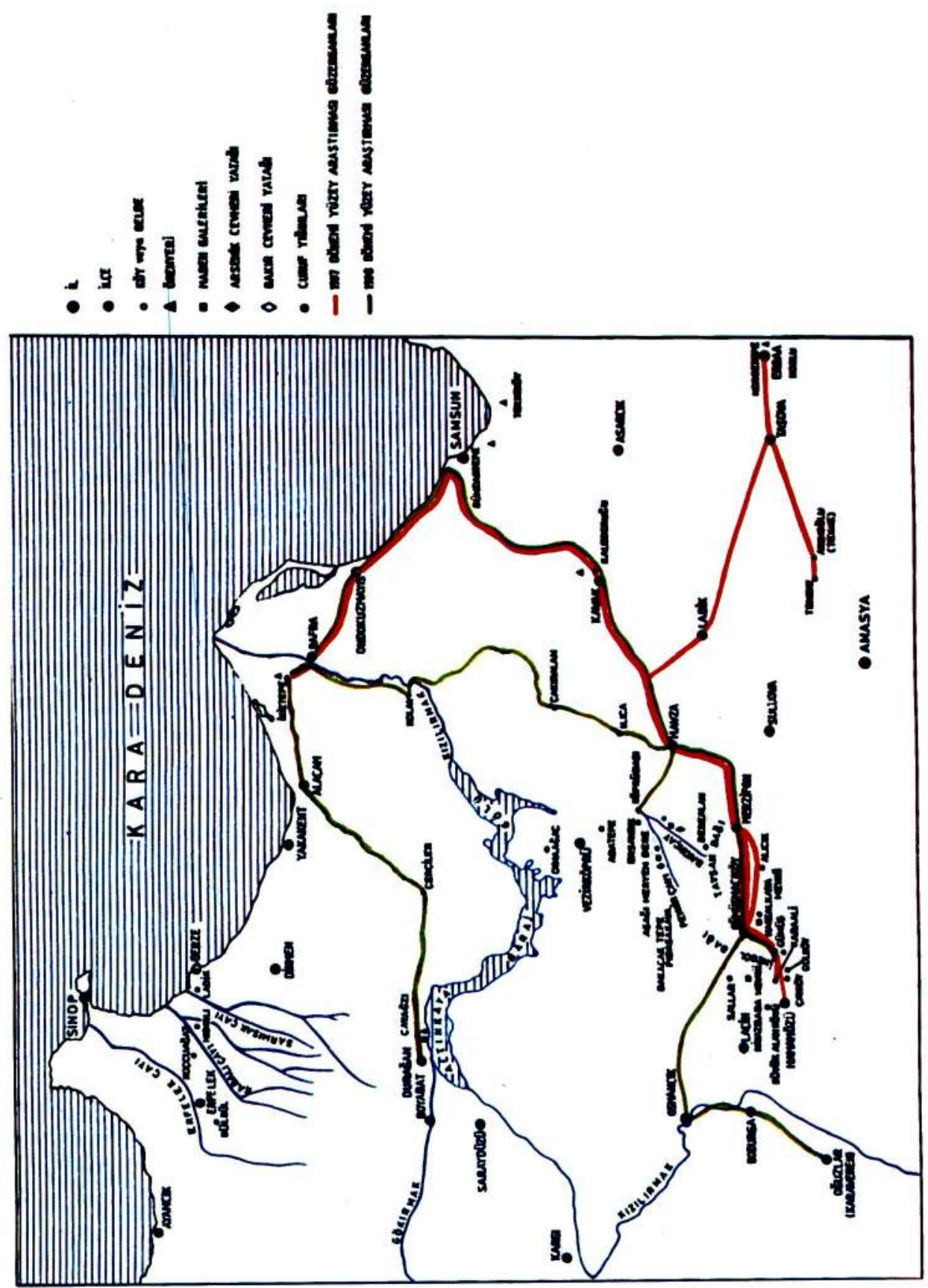

Önder Bilgi

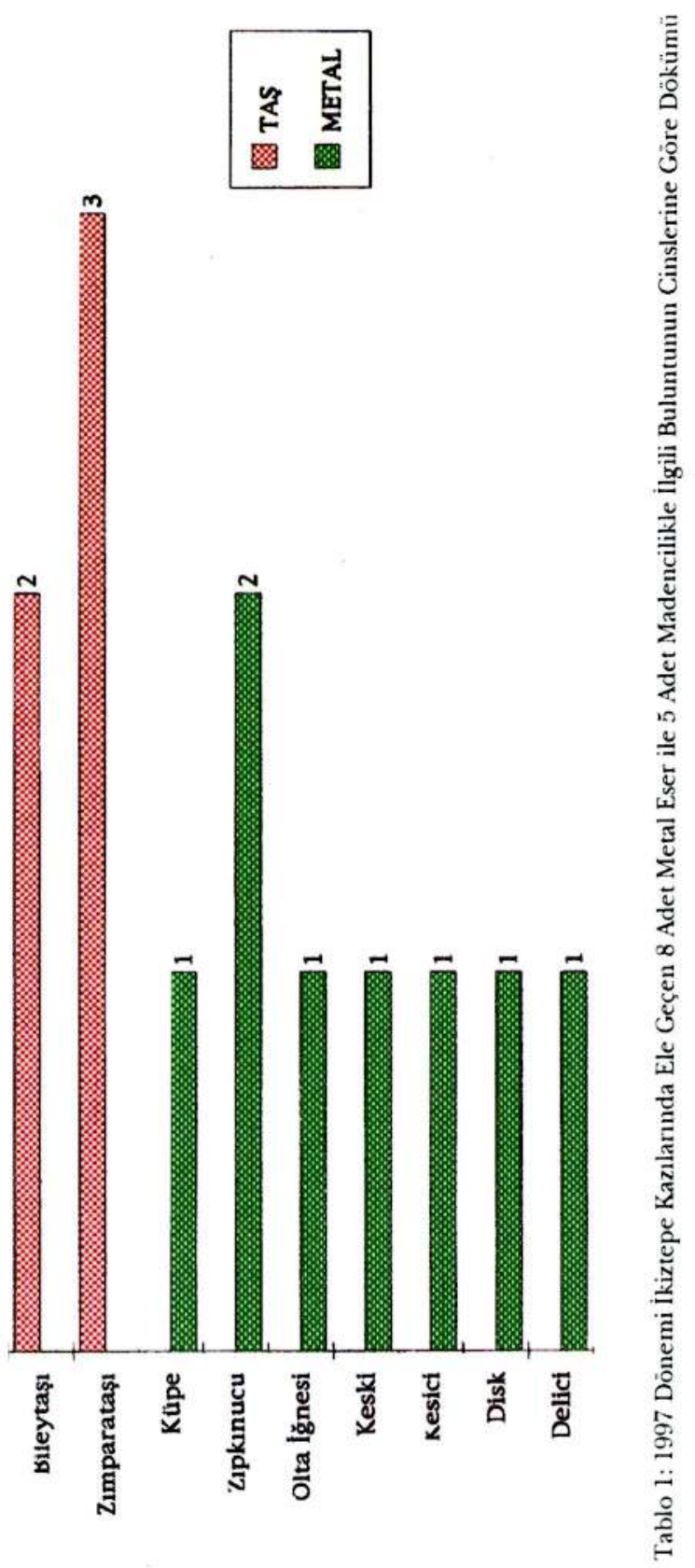




\section{Önder Bilgi}

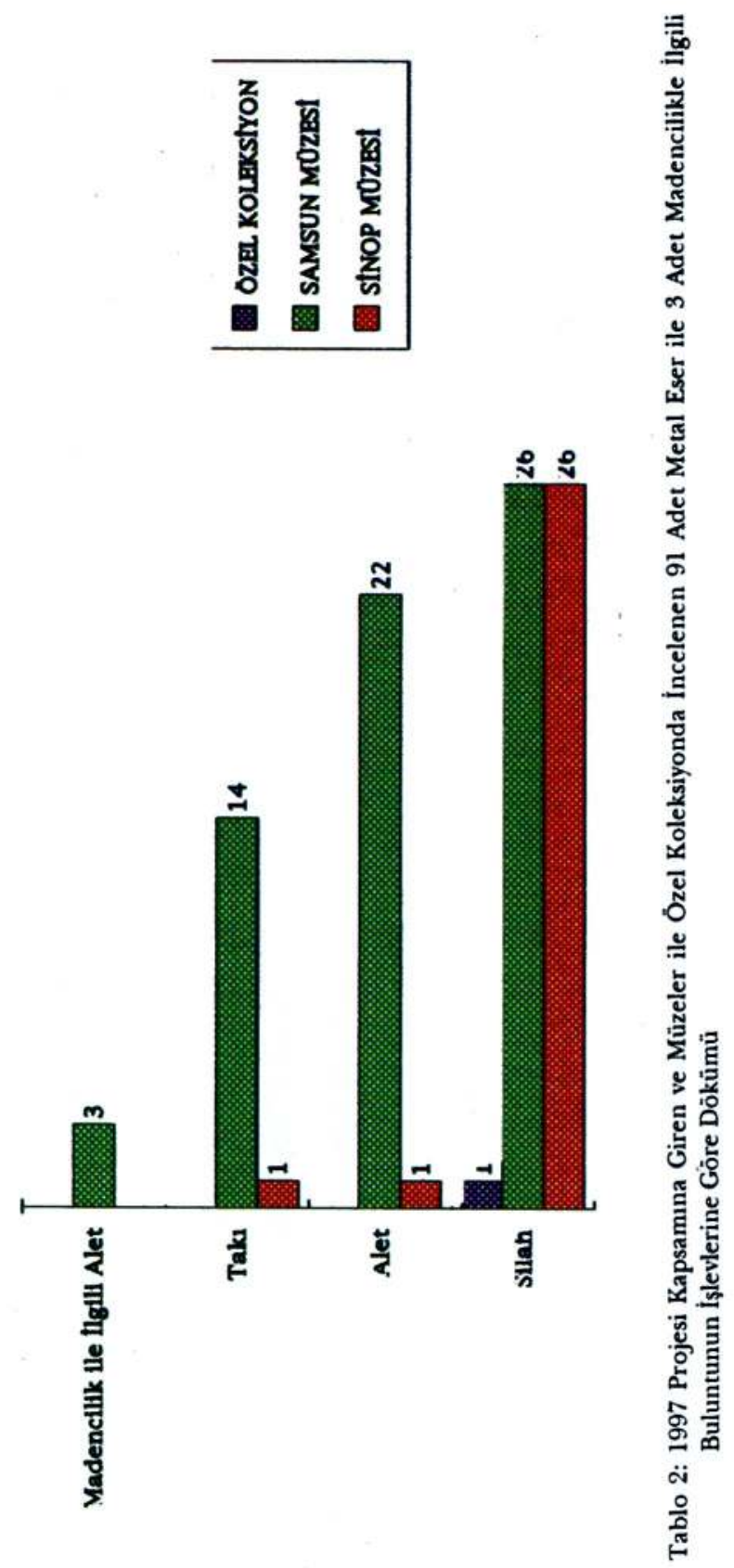


Önder Bilgi

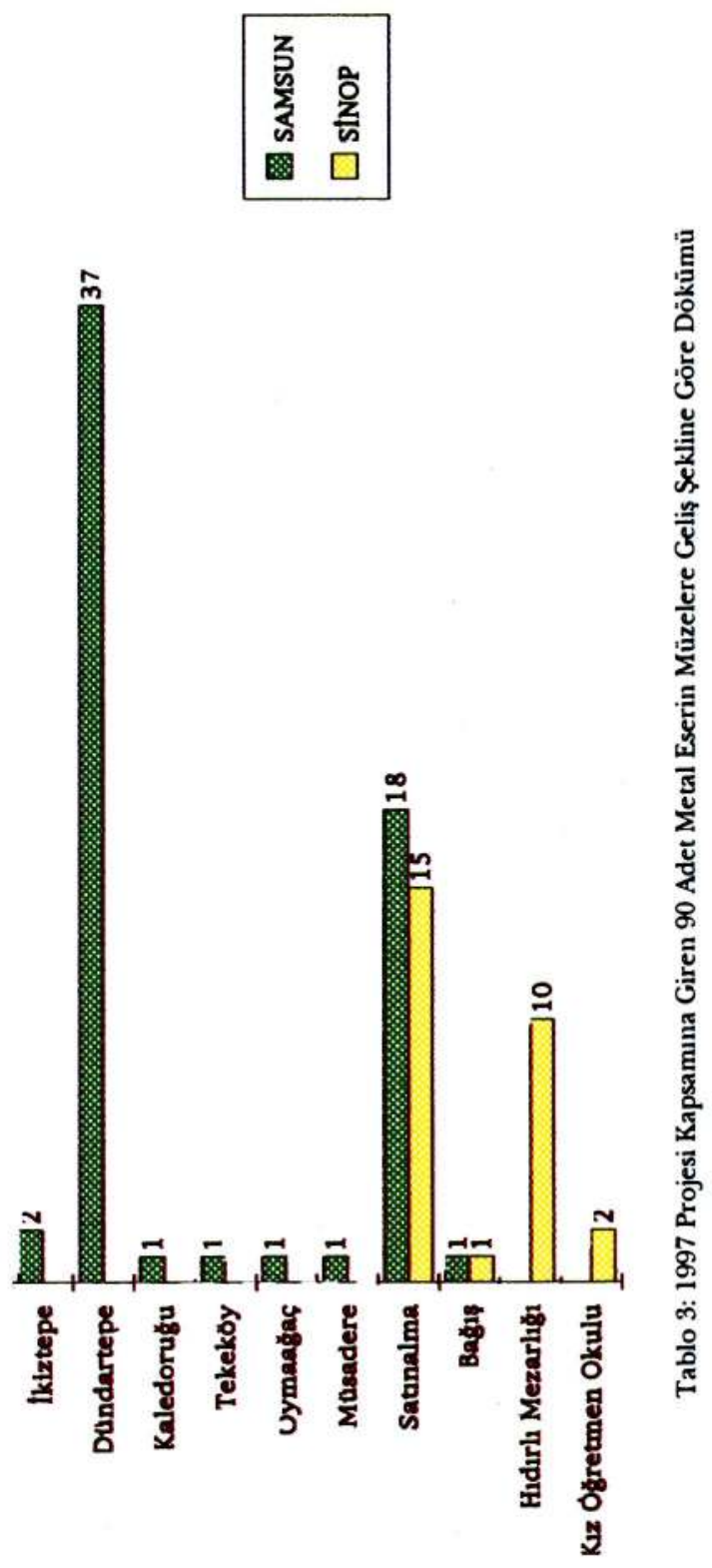


Önder Bilgi

篦喜

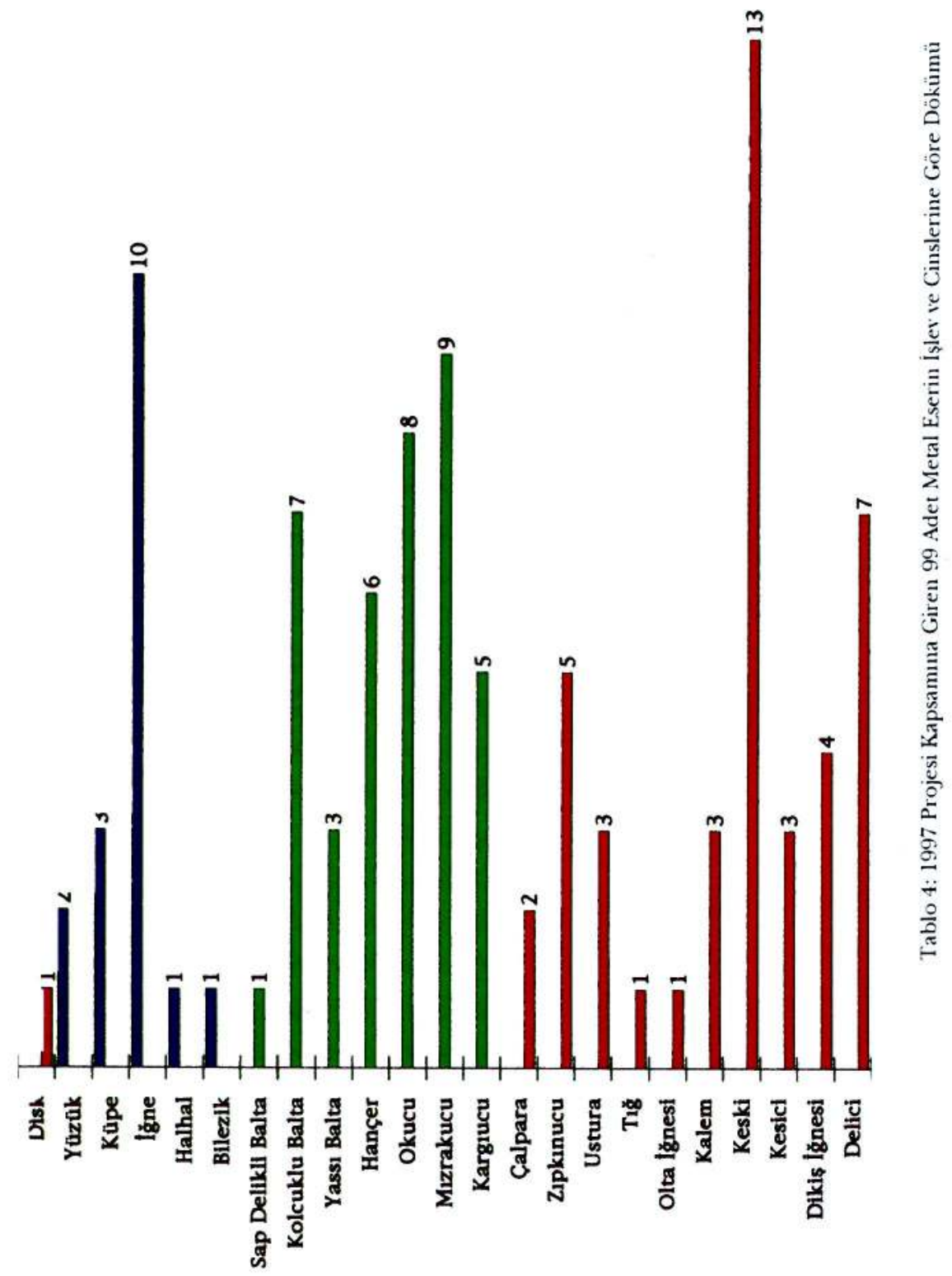


Önder Bilgi

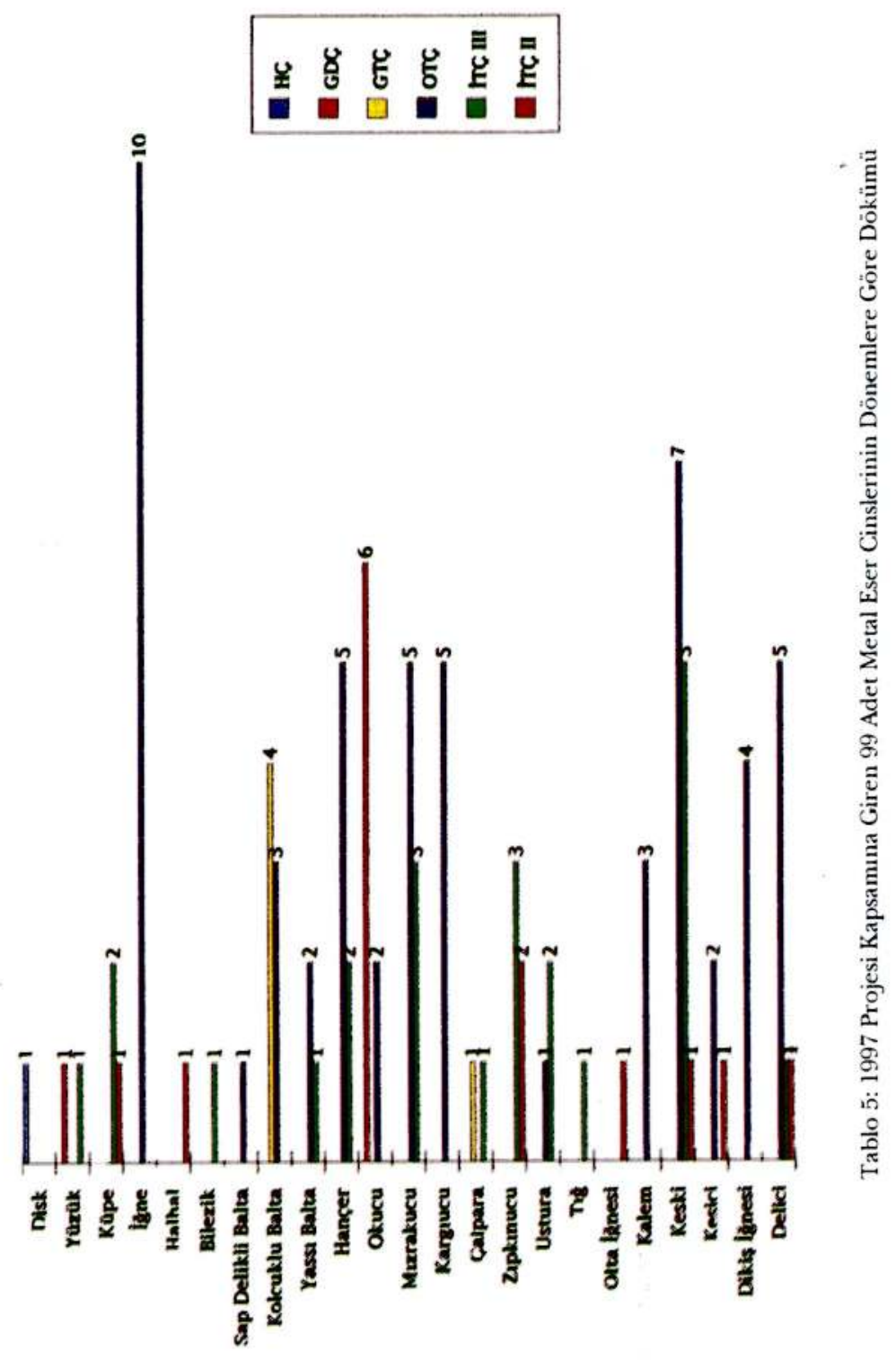


Önder Bilgi

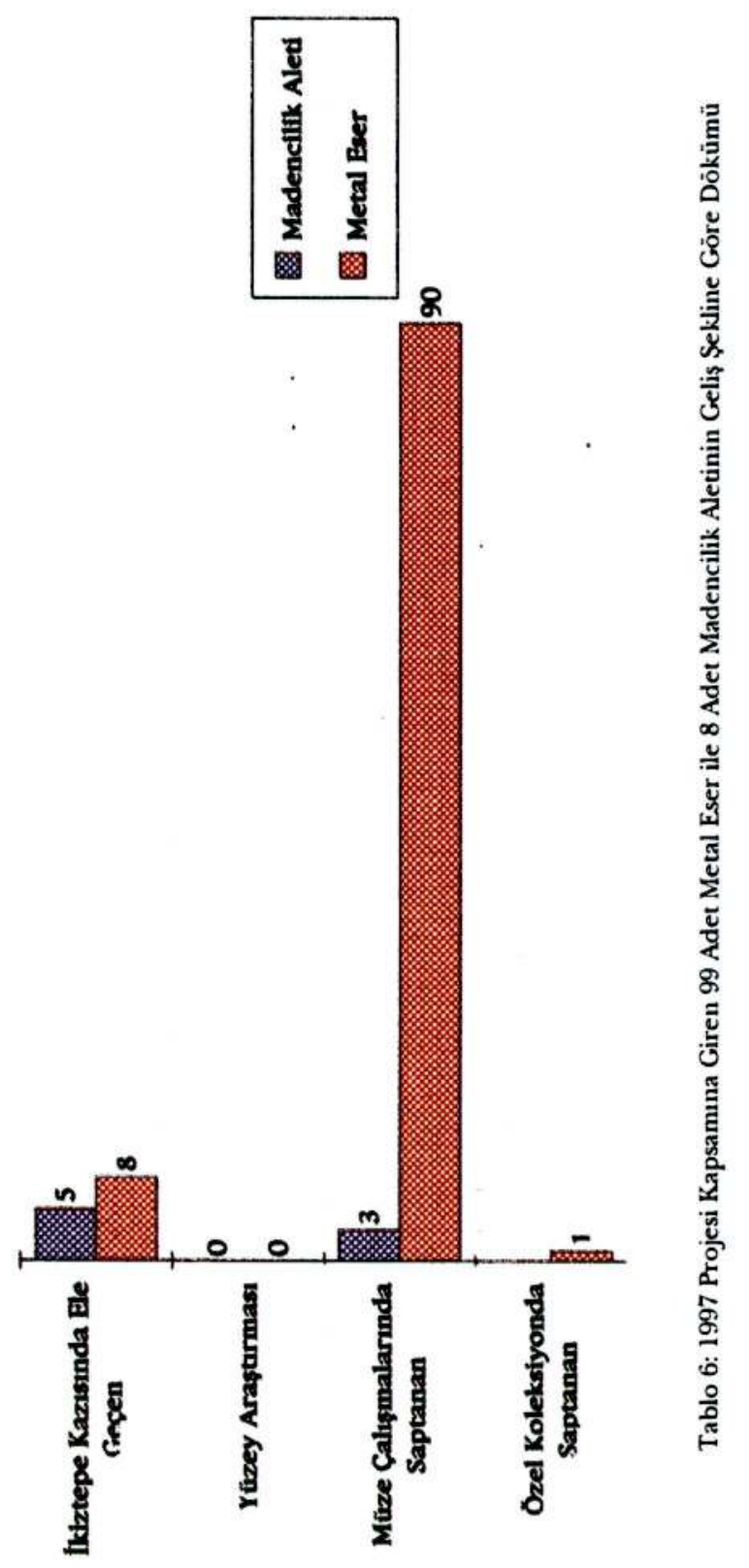




\section{Önder Bilgi}

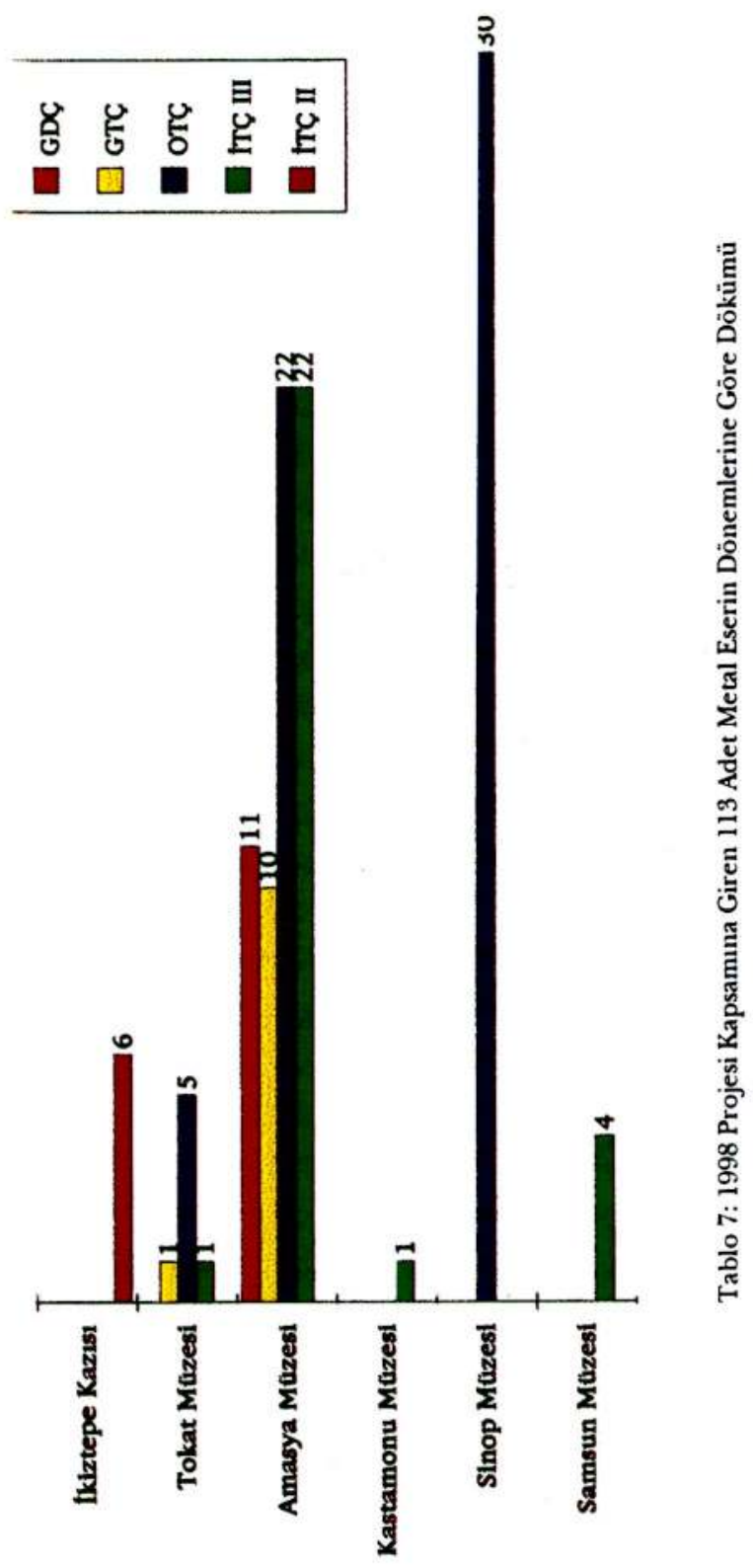


Önder Bilgi

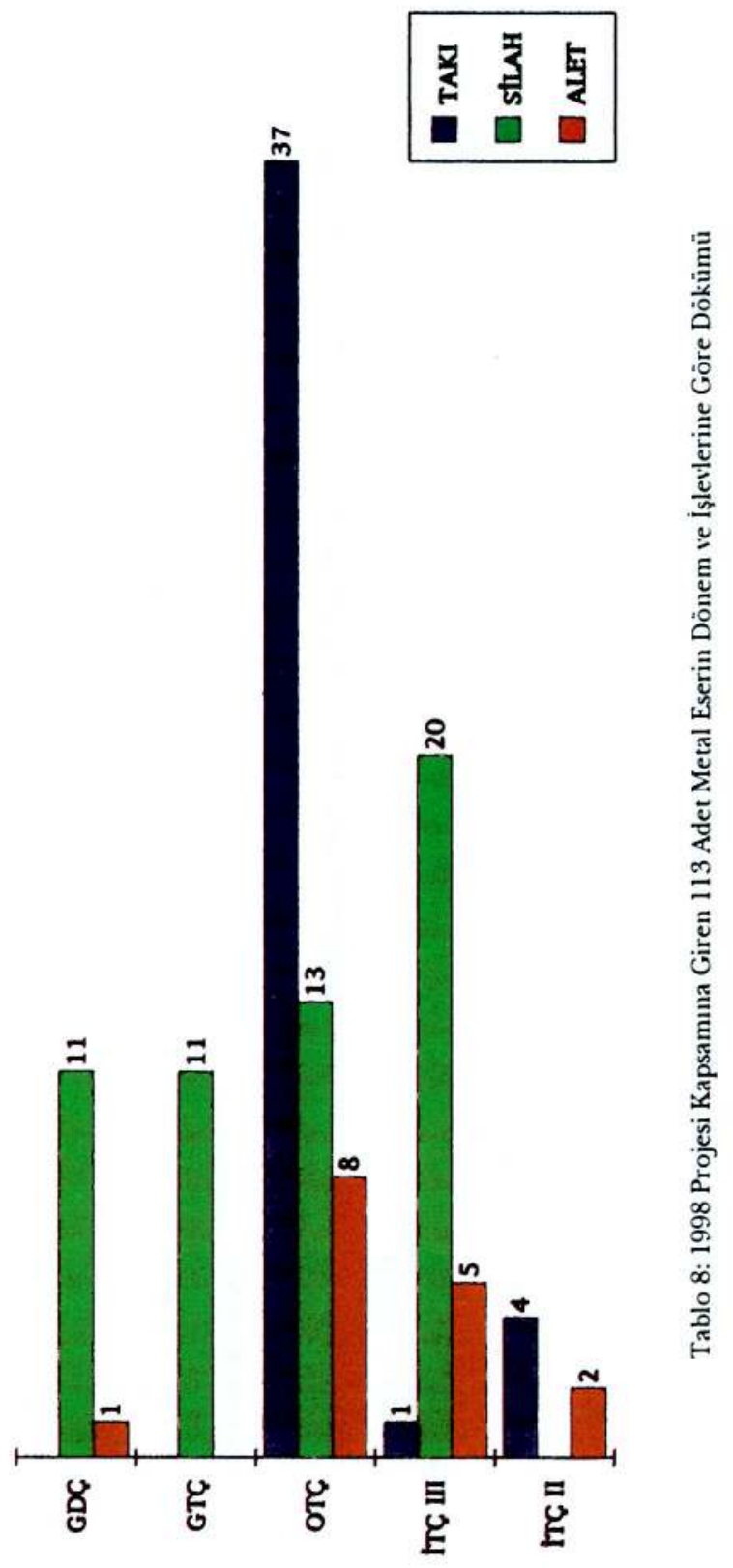


Önder Bilgi

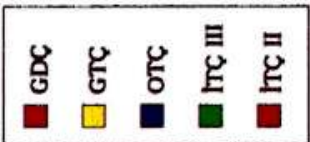

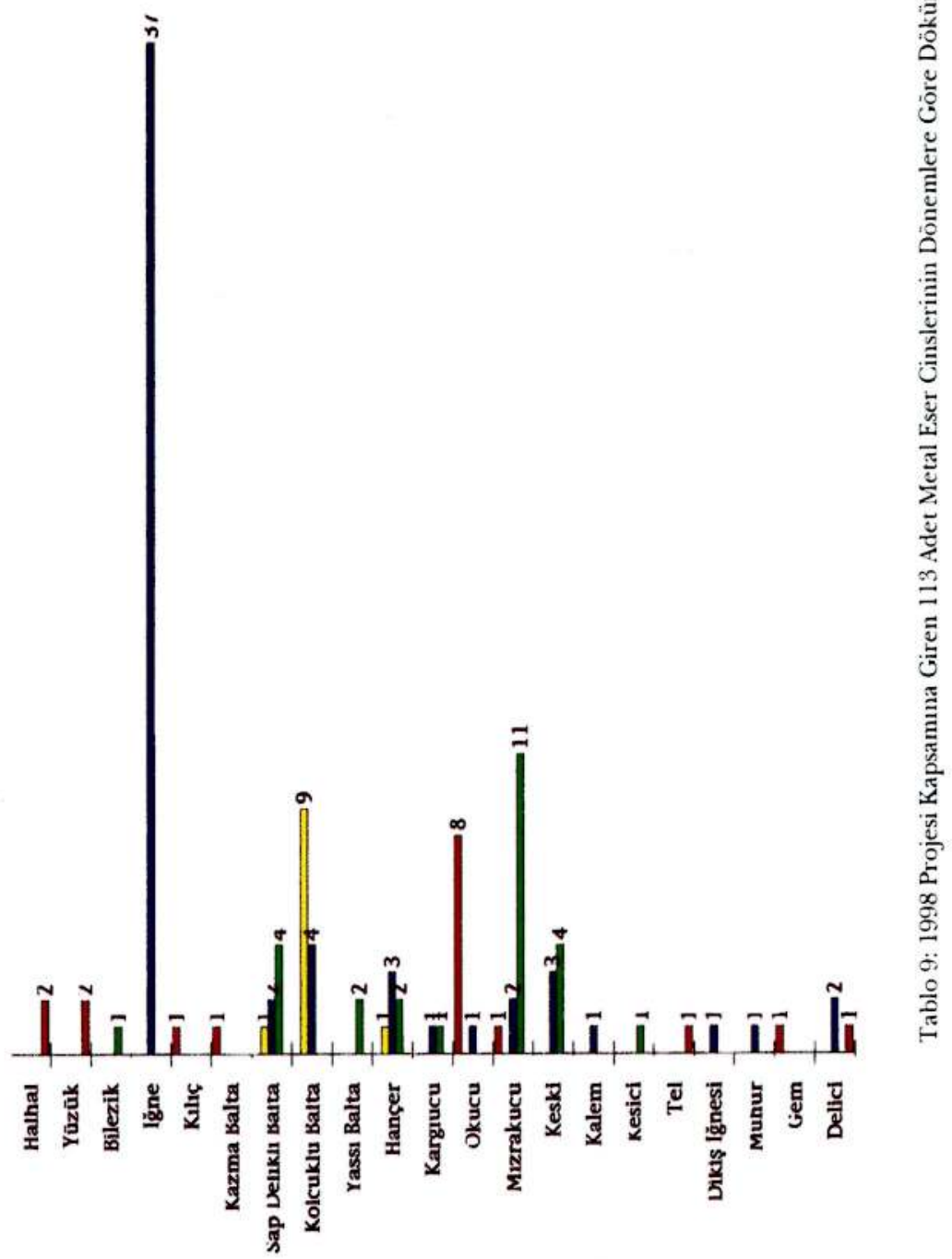


Önder Bilgi

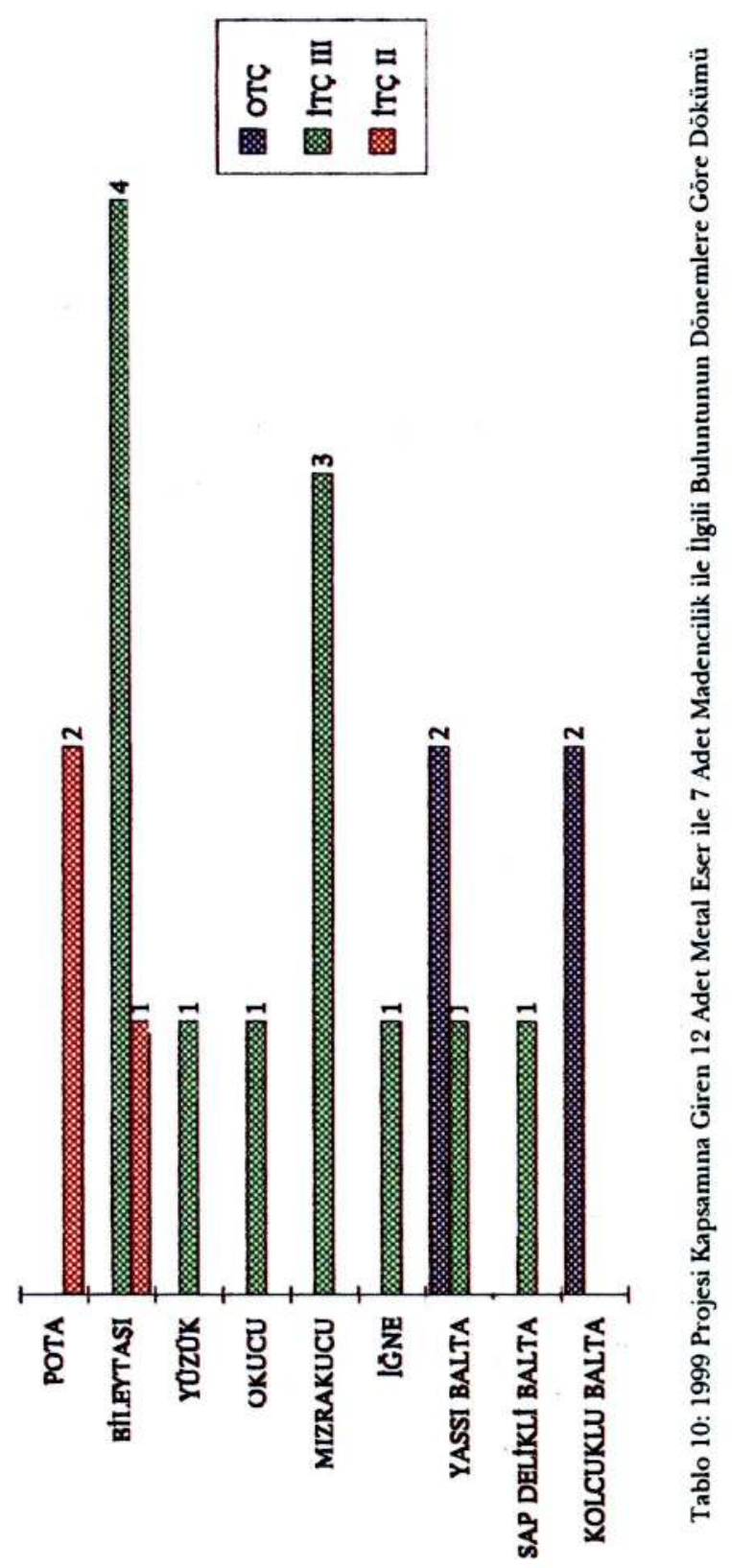


Önder Bilgi
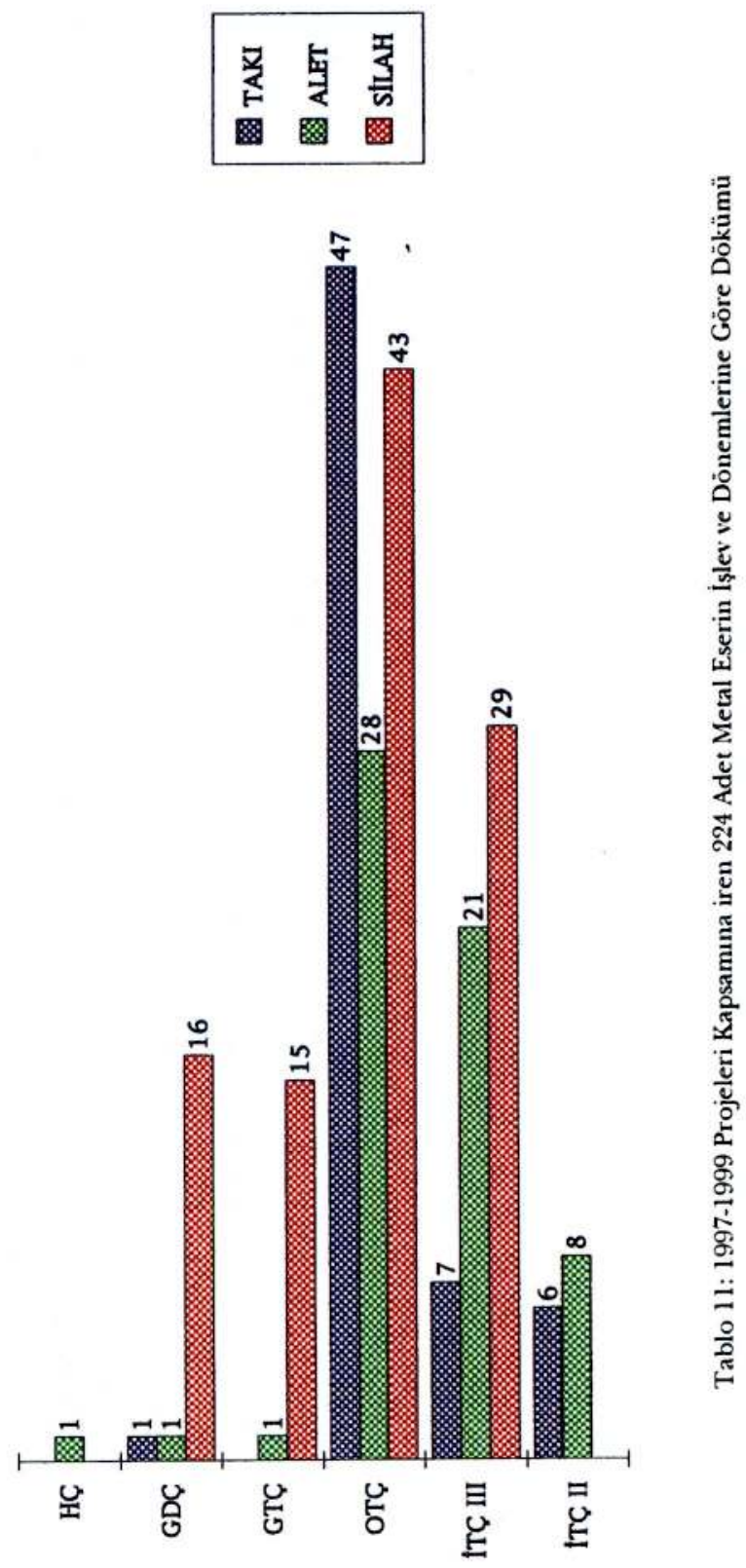


\section{Önder Bilgi}

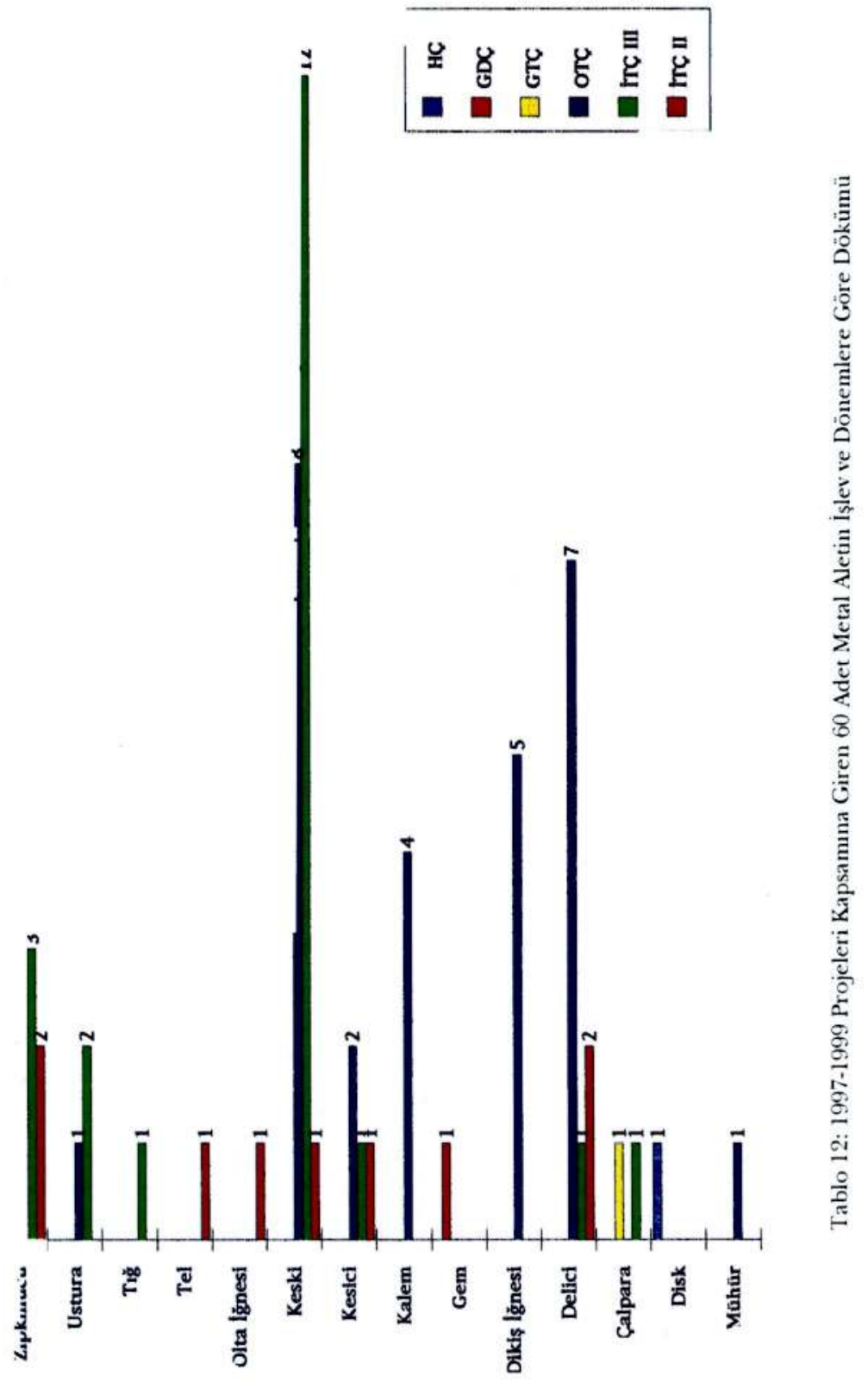


Önder Bilgi

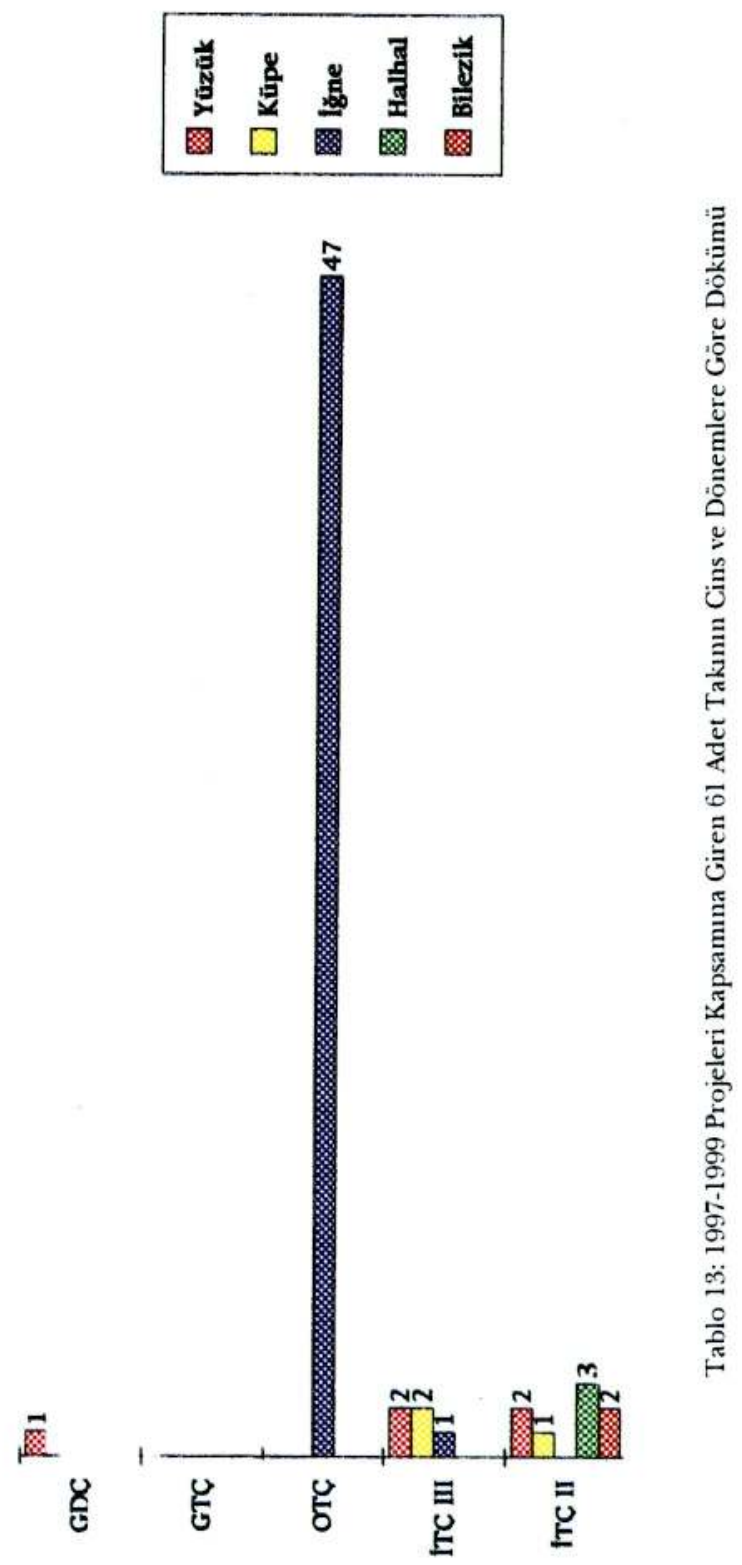


Önder Bilgi
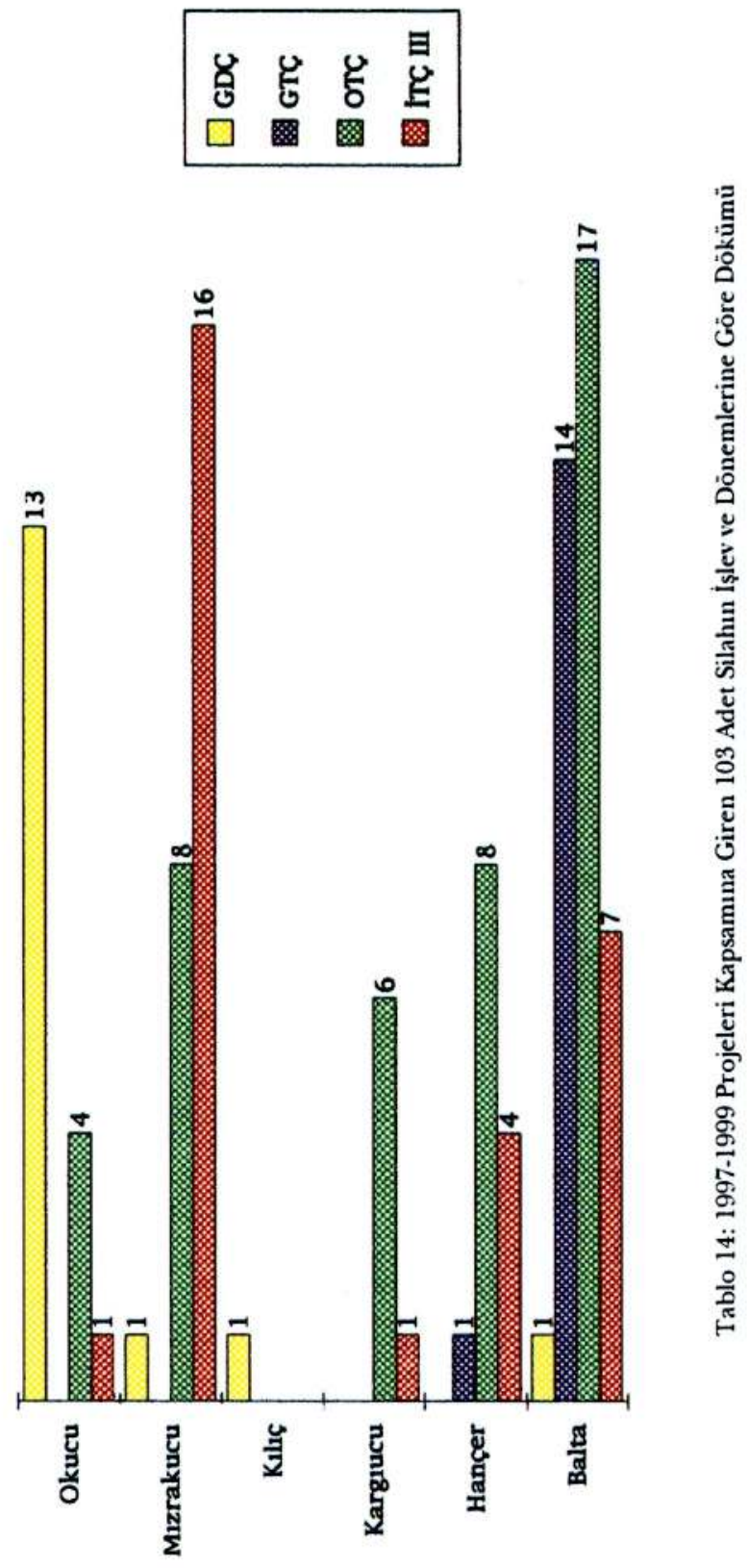
Önder Bilgi

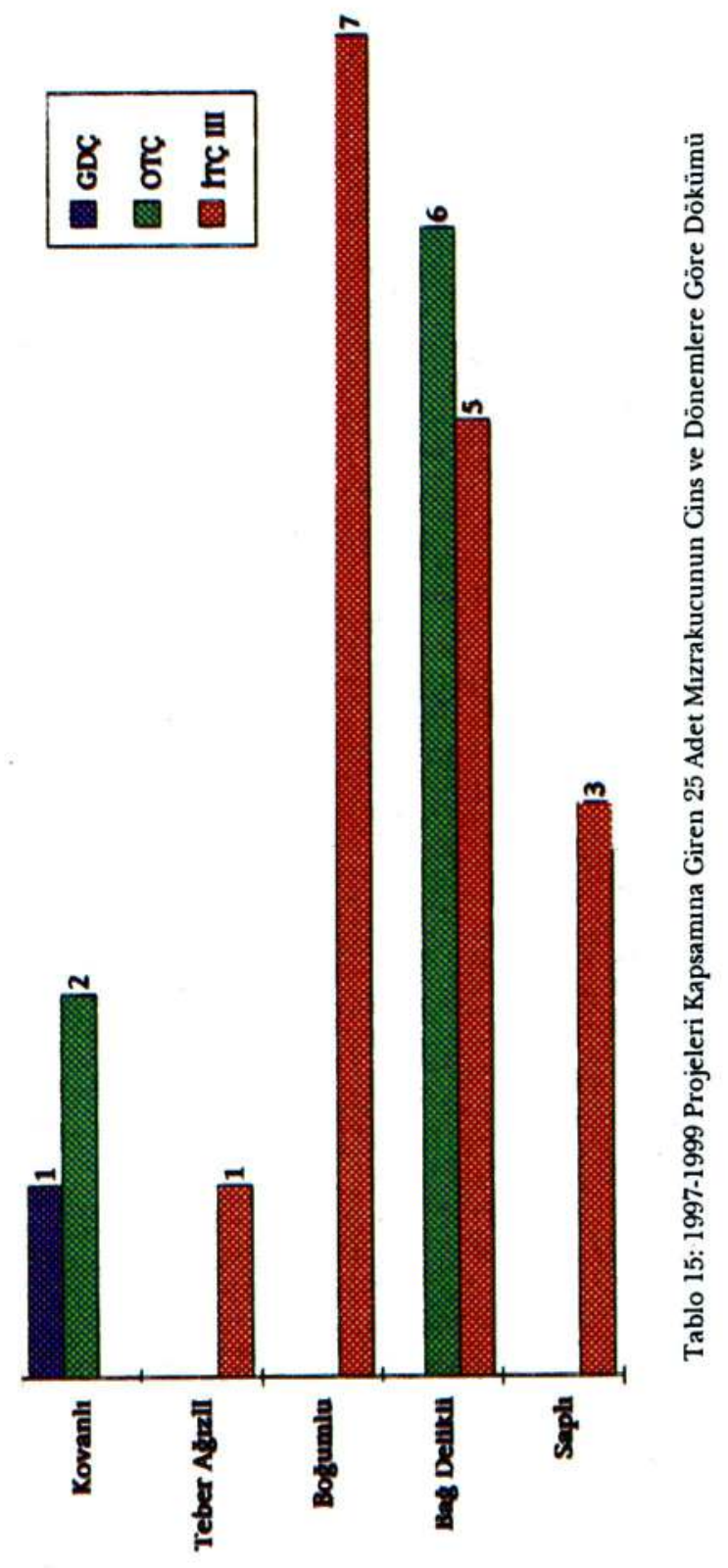




\section{Önder Bilgi}

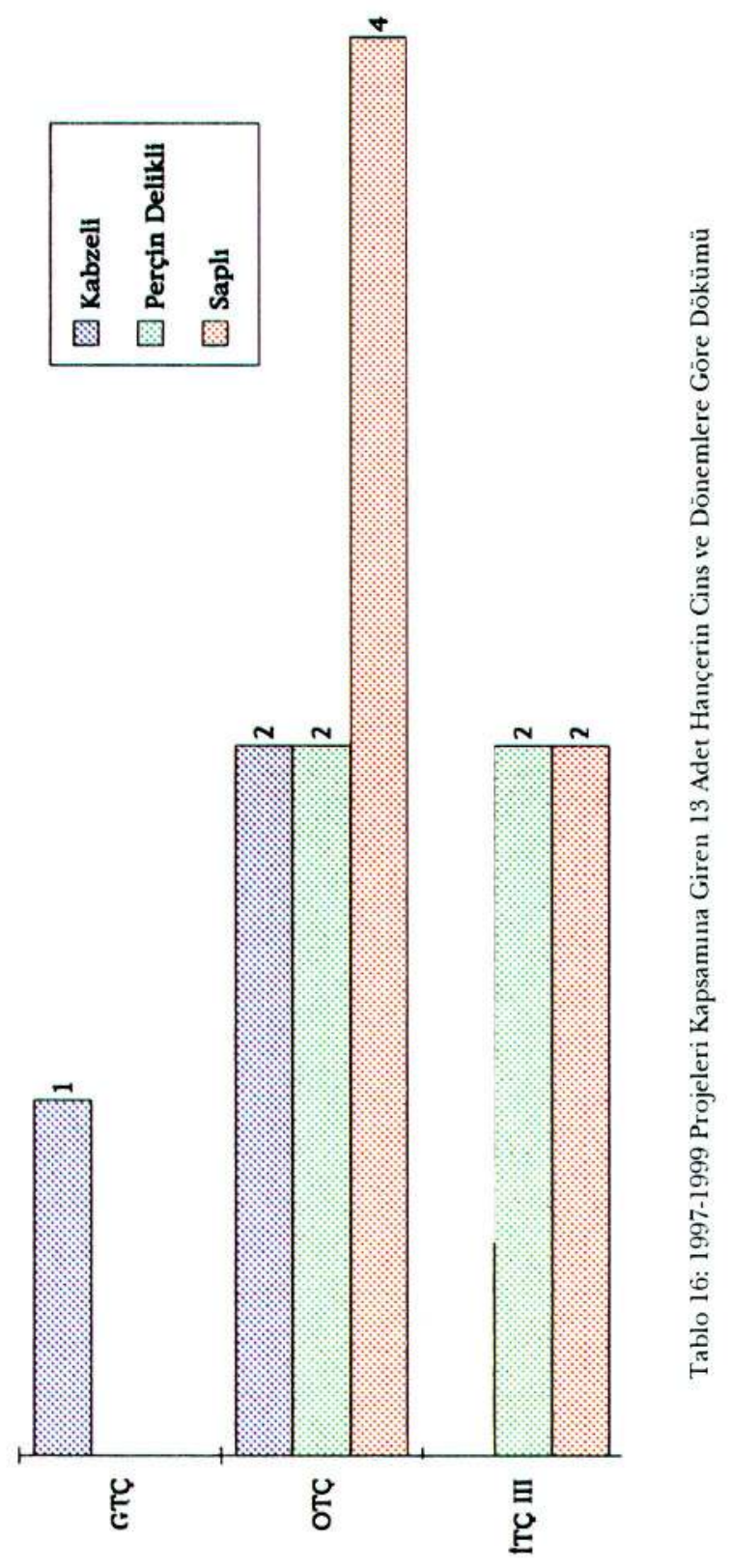


Önder Bilgi

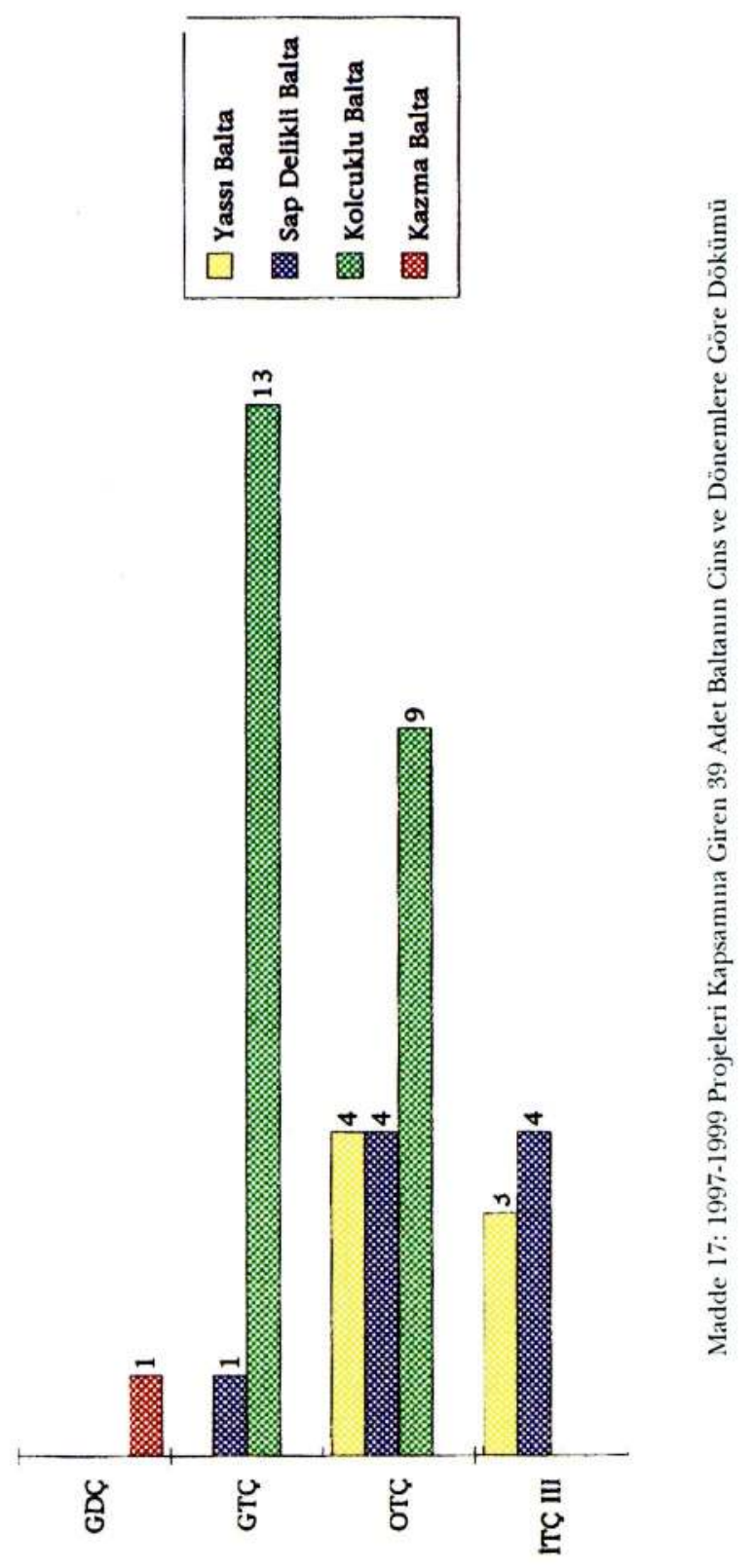




\section{Önder Bilgi}

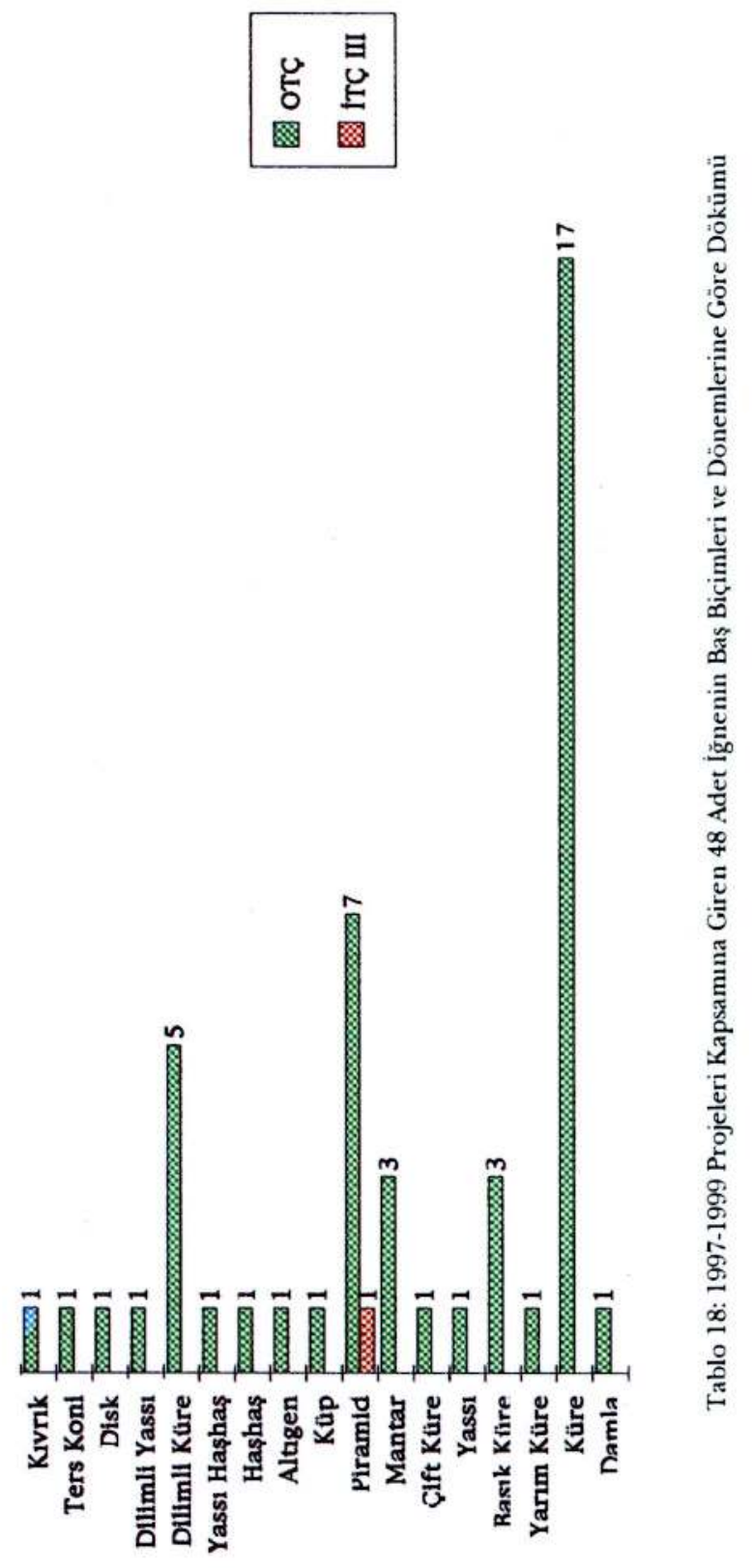


Önder Bilgi

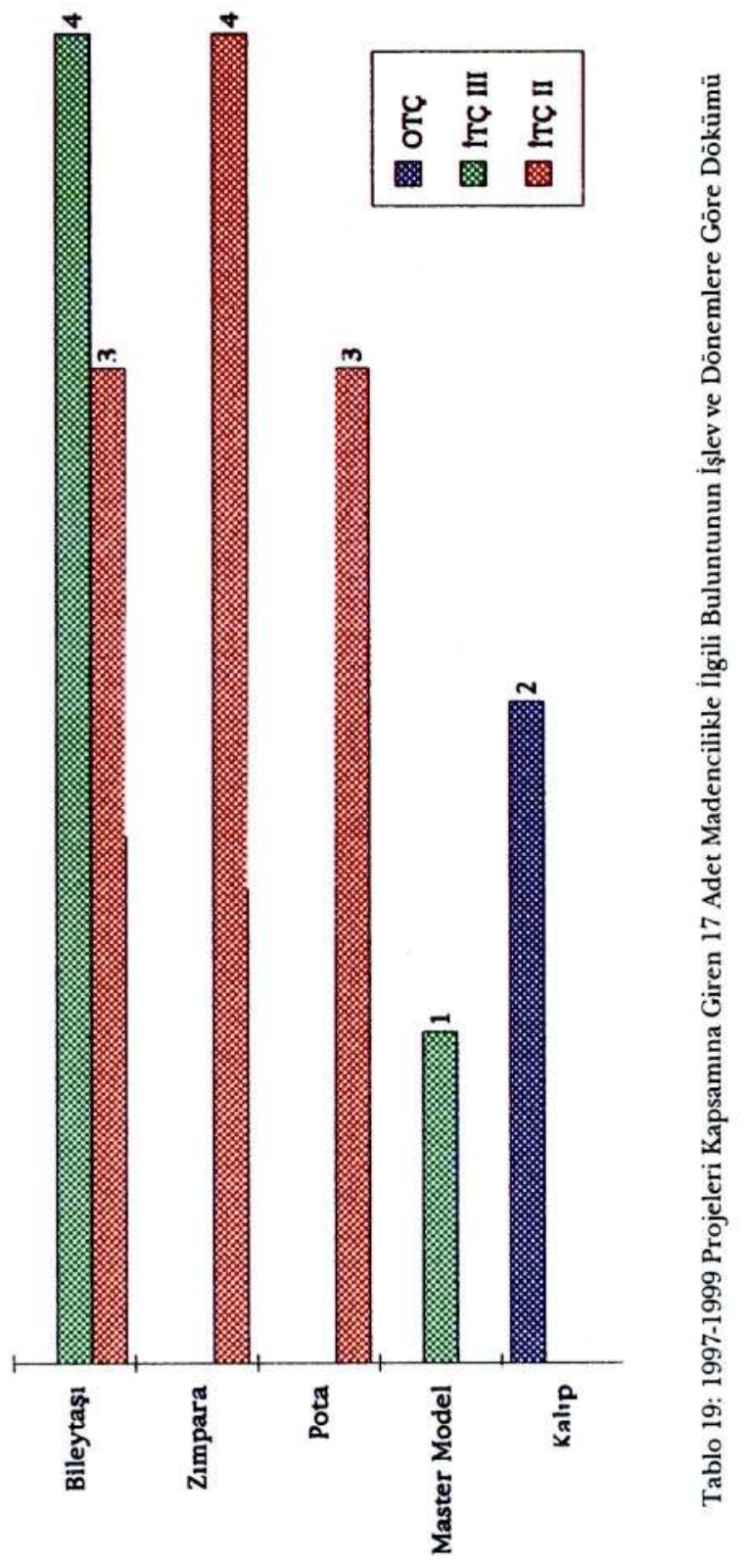





\section{Önder Bilgi}

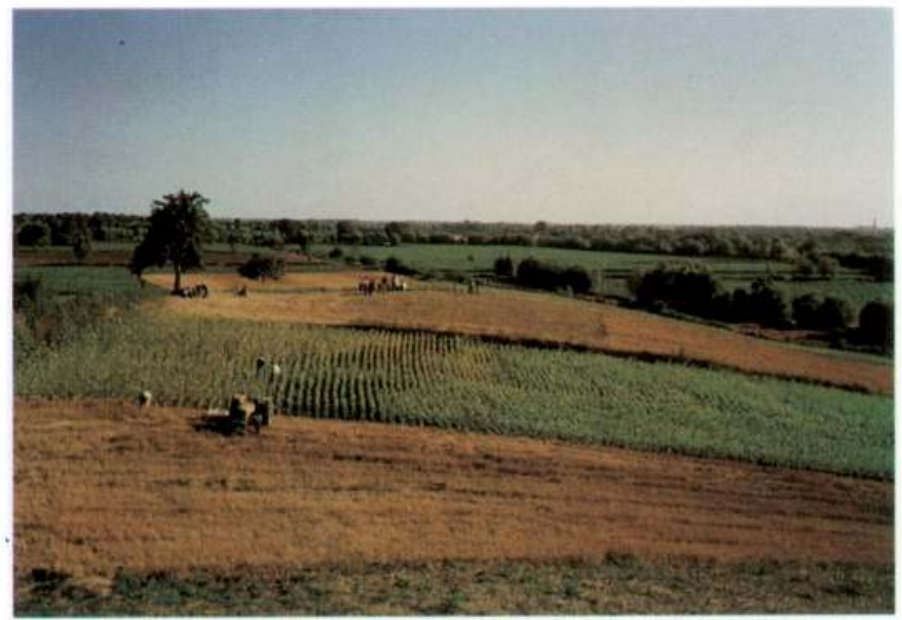

Resim 1: İkiztepe, Tepe III, Gũneyden Genel Görünüm

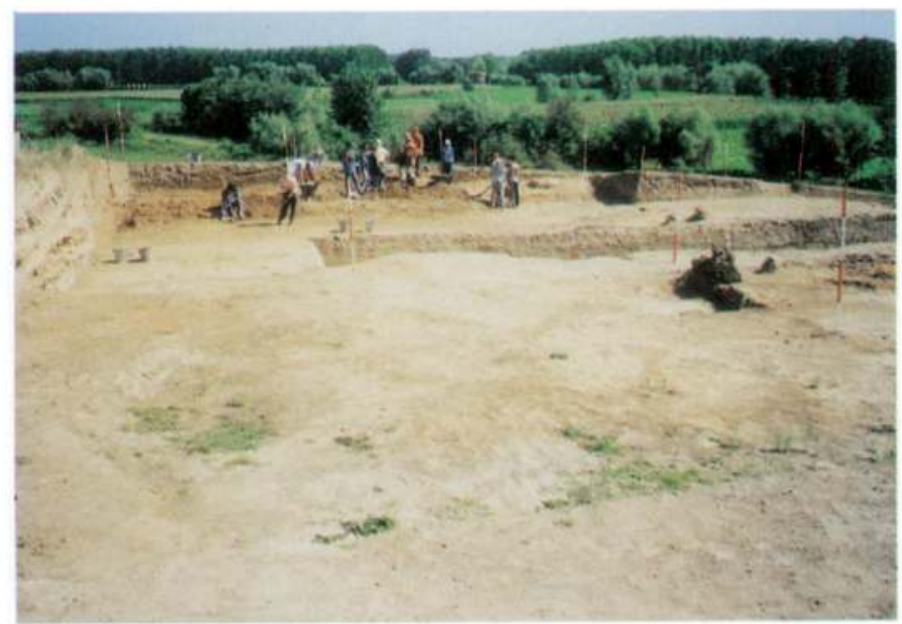

Resim 2: Ilkiztepe, Tepe III "L" Açması 


\section{Önder Bilgi}

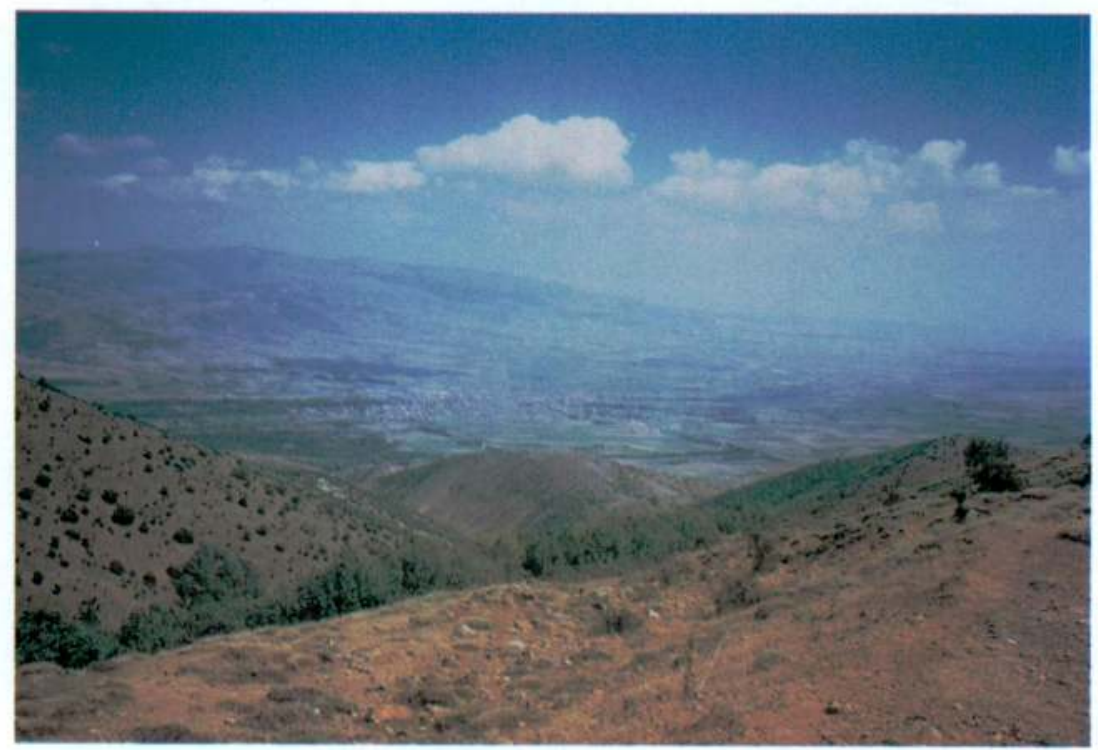

Resim 3: Merzifon-Tavşandağ, Güneyden Genel Gōrünüm

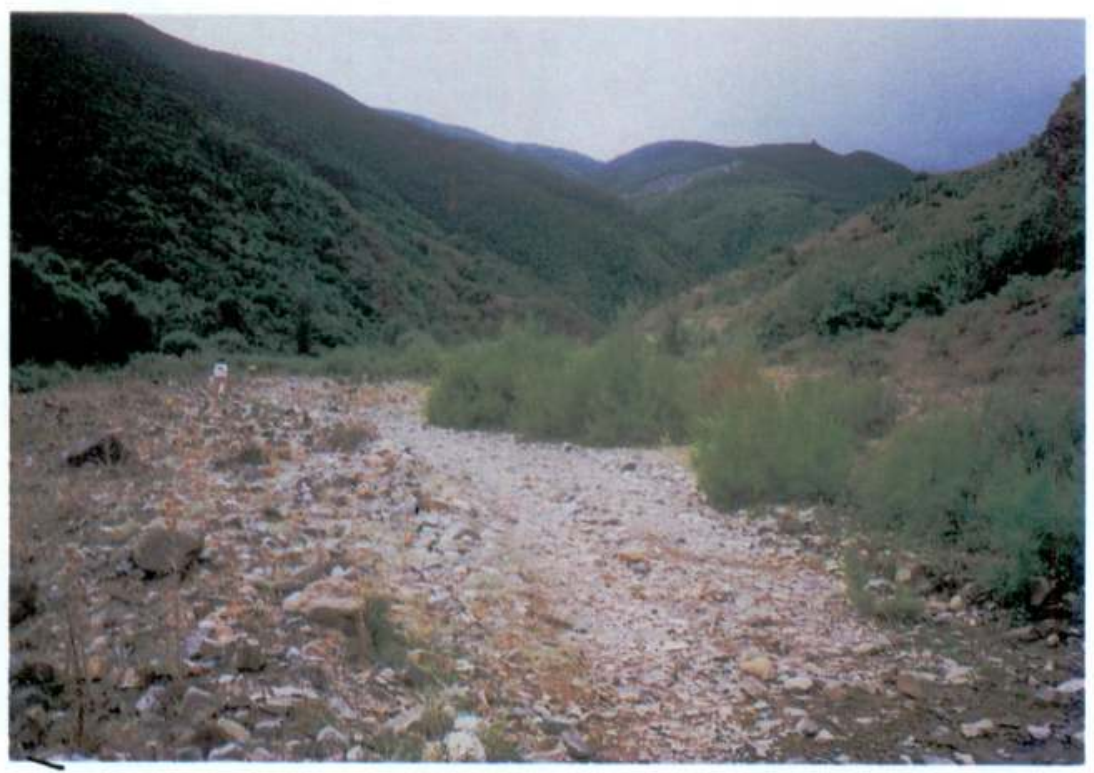

Resim 4: Merzifon-Tavşandağ. Bakırçay Vadisi, Kuzeyden Genel Görūnüm 


\section{Önder Bilgi}

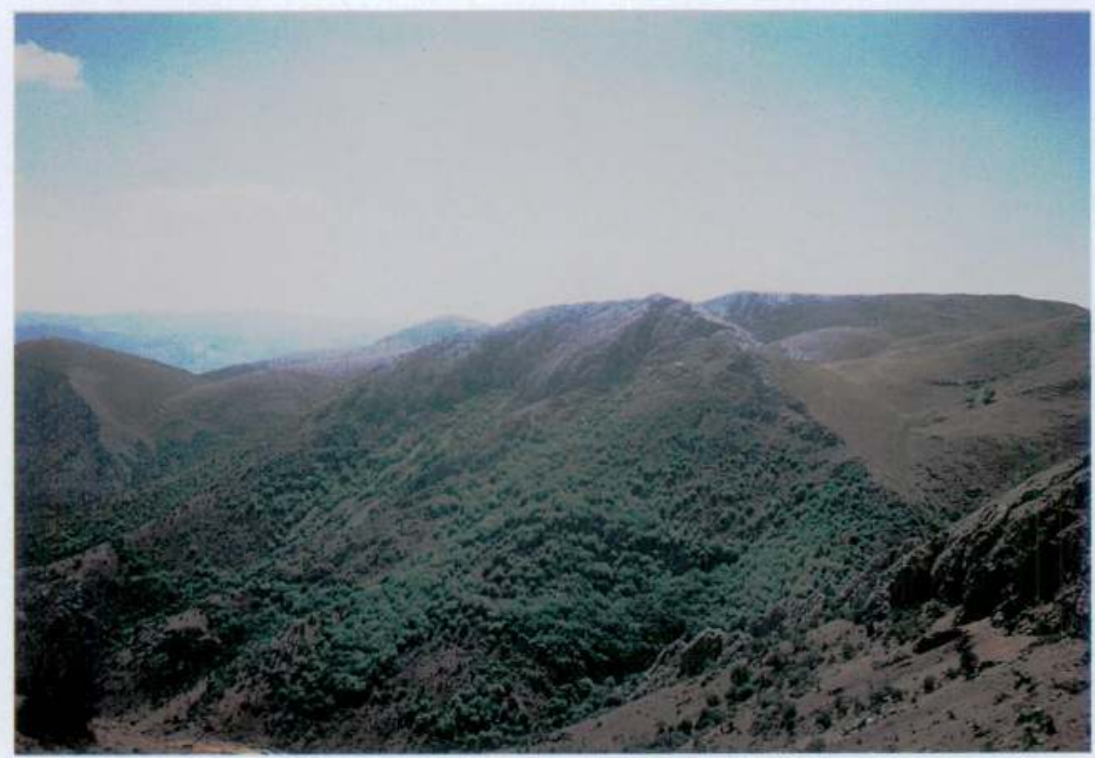

Resim 5: Gümüşhacikōy-İnegōl Dağı

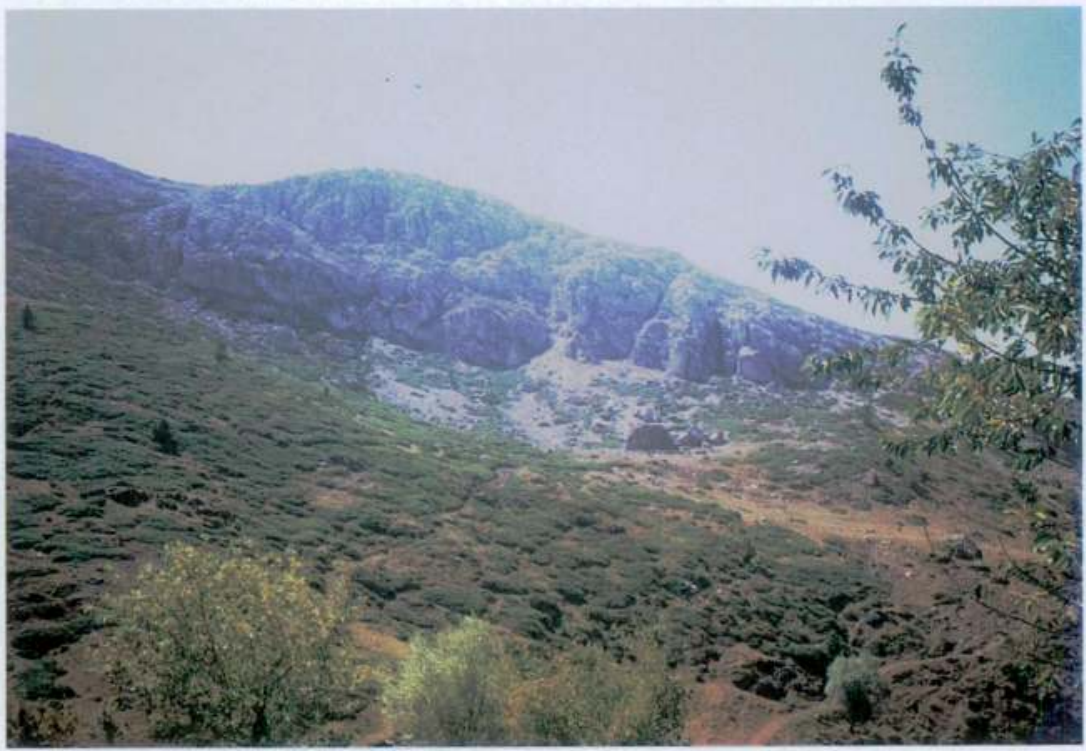

Resim 6: Gümūşhacıköy-İnegöl Dağı, Kartalkaya Mevkii 


\section{Önder Bilgi}

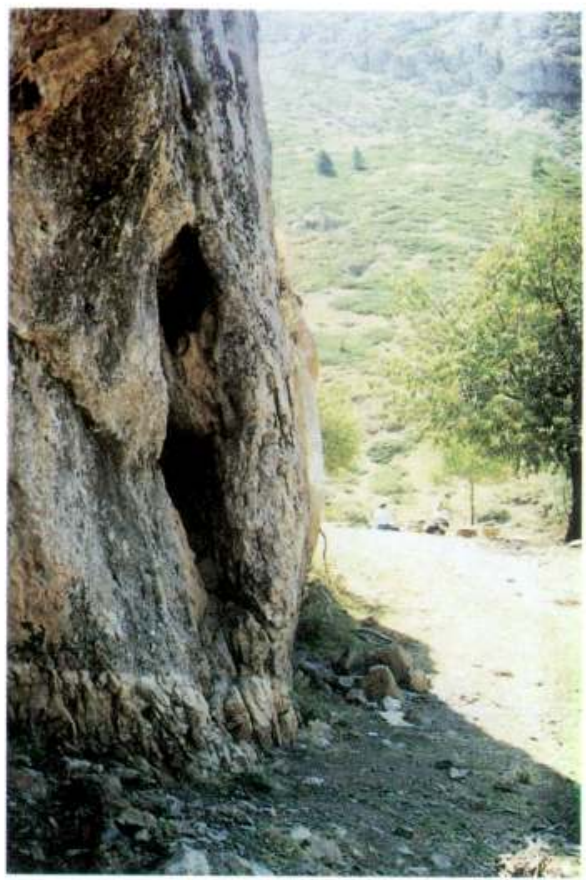

Resim 7: Gümüșhacıköy-Inegōl Dağı, Nivazbaba Mevkii Maden Galerisi

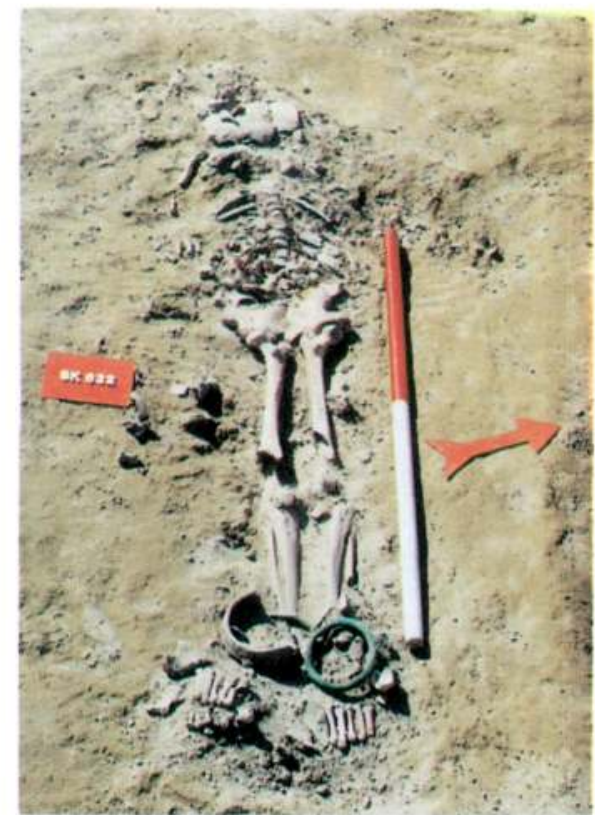

Basit Toprak Mezarunda Bir Halhall Iskelet 


\section{Önder Bilgi}

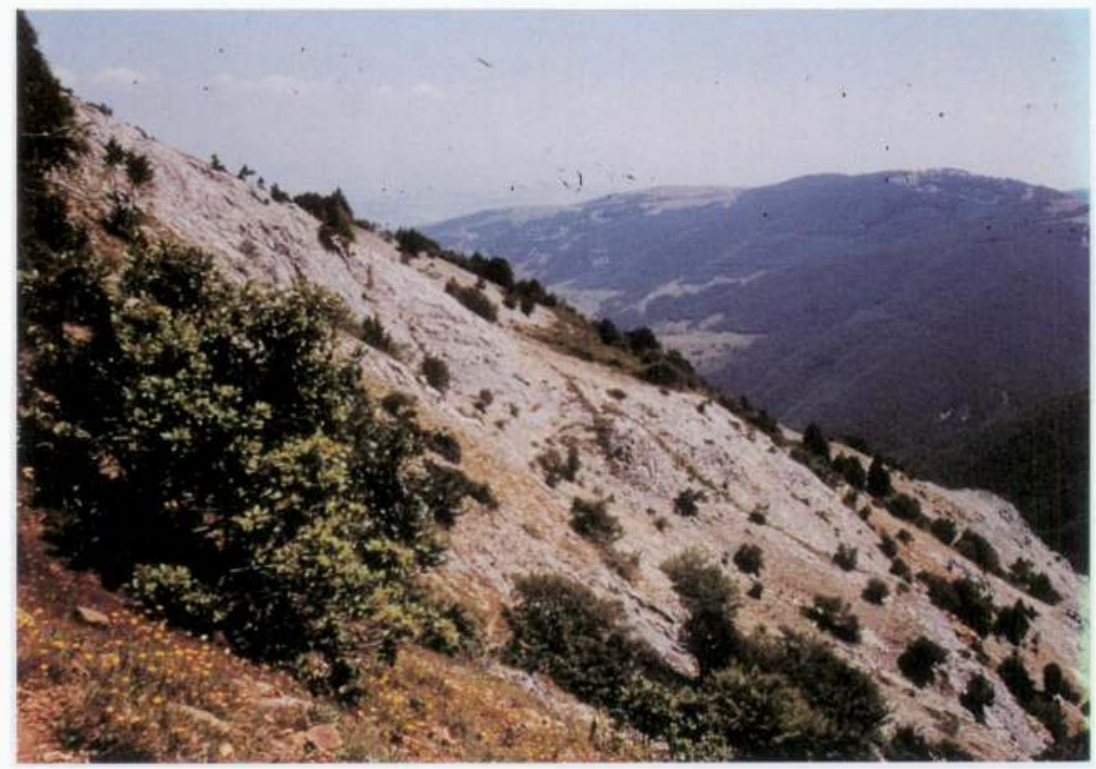

Resim 9: Merzifon-Tarșan Dağ Bakacak Tepe Pırasakaya Mevkii Arsenik (arsenoprit) Yatağı

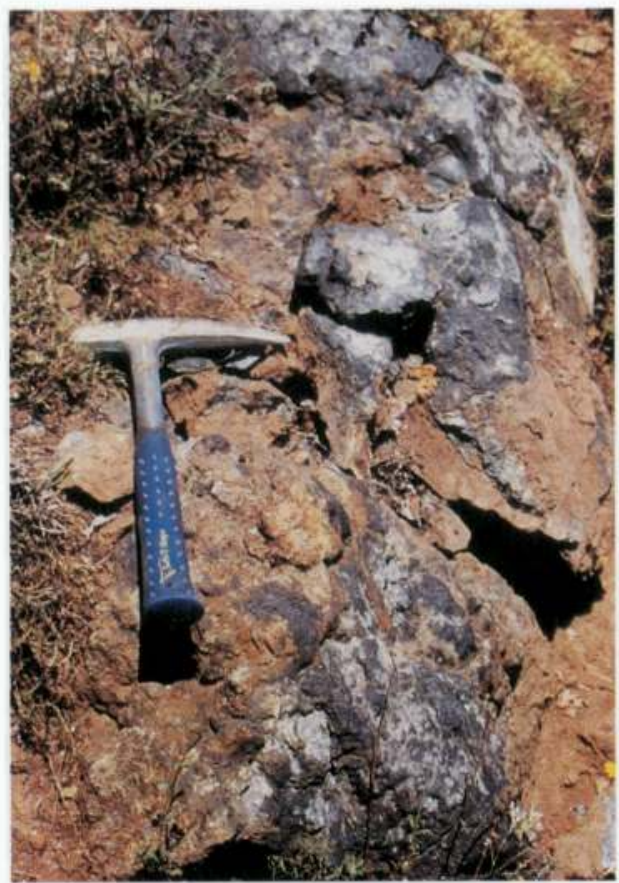

Resim 10: Arsenoprit (demir + arsenik + kükürt) Cevheri Örneği 


\section{Önder Bilgi}

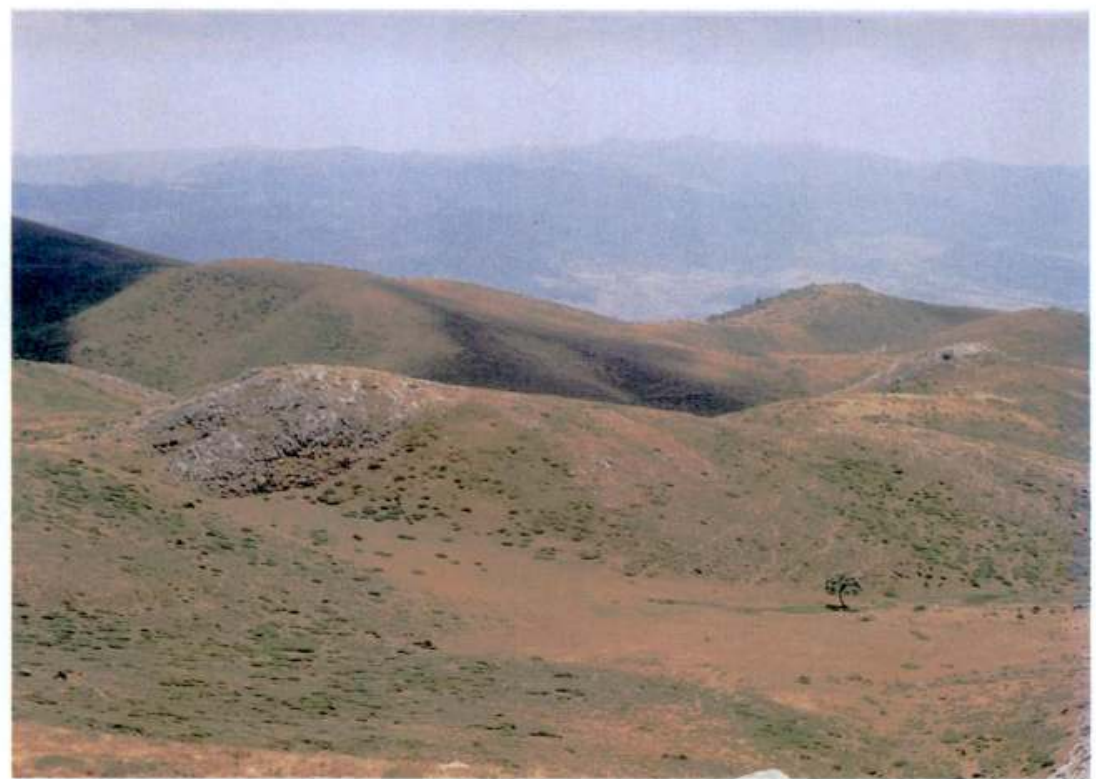

Resim 11: Gümüşhacıköy-İnegōl Dağı, Karlıdoruk Tepesi

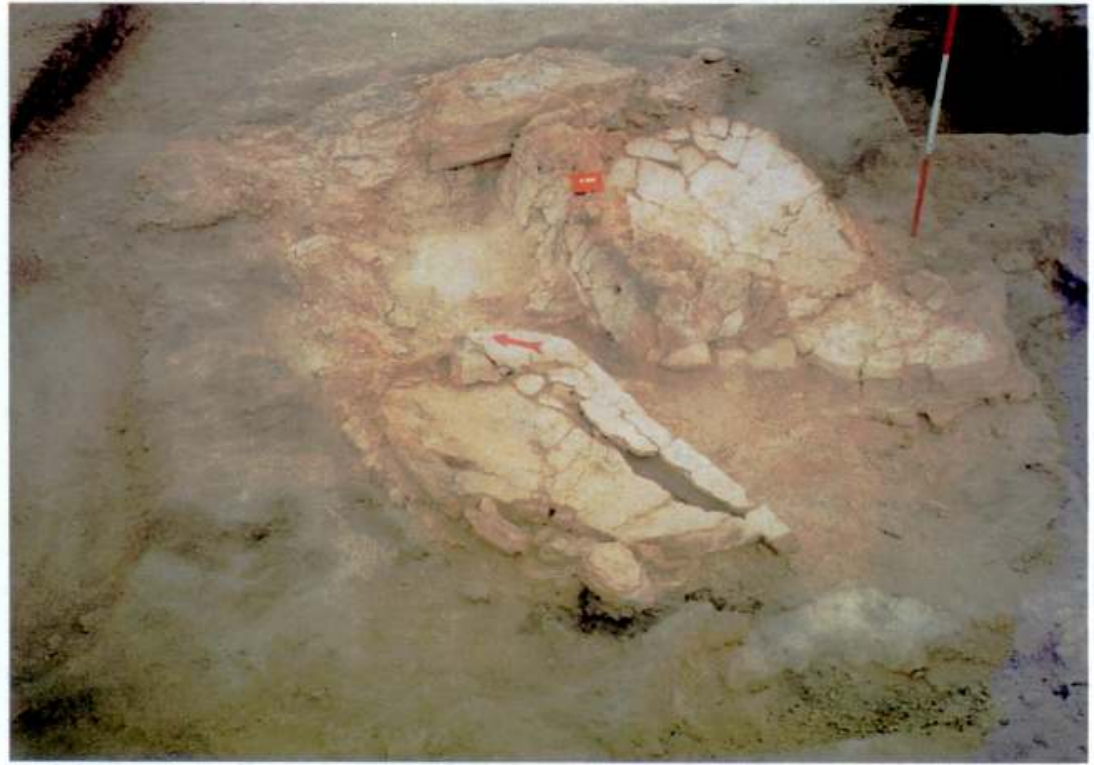

Resim 12: İkiztepe-Tepe III, 4. Mimari Tabaka Atölye Kalıntlanı, ITC̣ III 


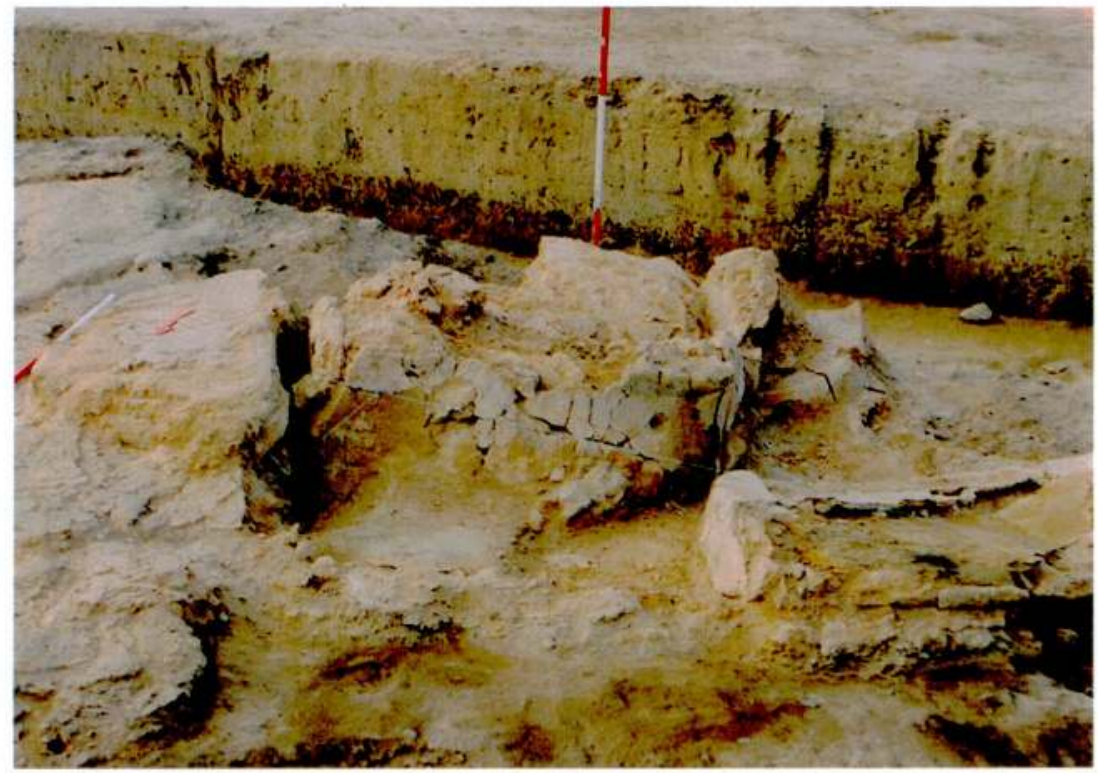

Resim 13: İkiztepe-Tepe III, 4. Mimari Tabaka Atōlyenin İşlik Kalıntılanı, ITCC III

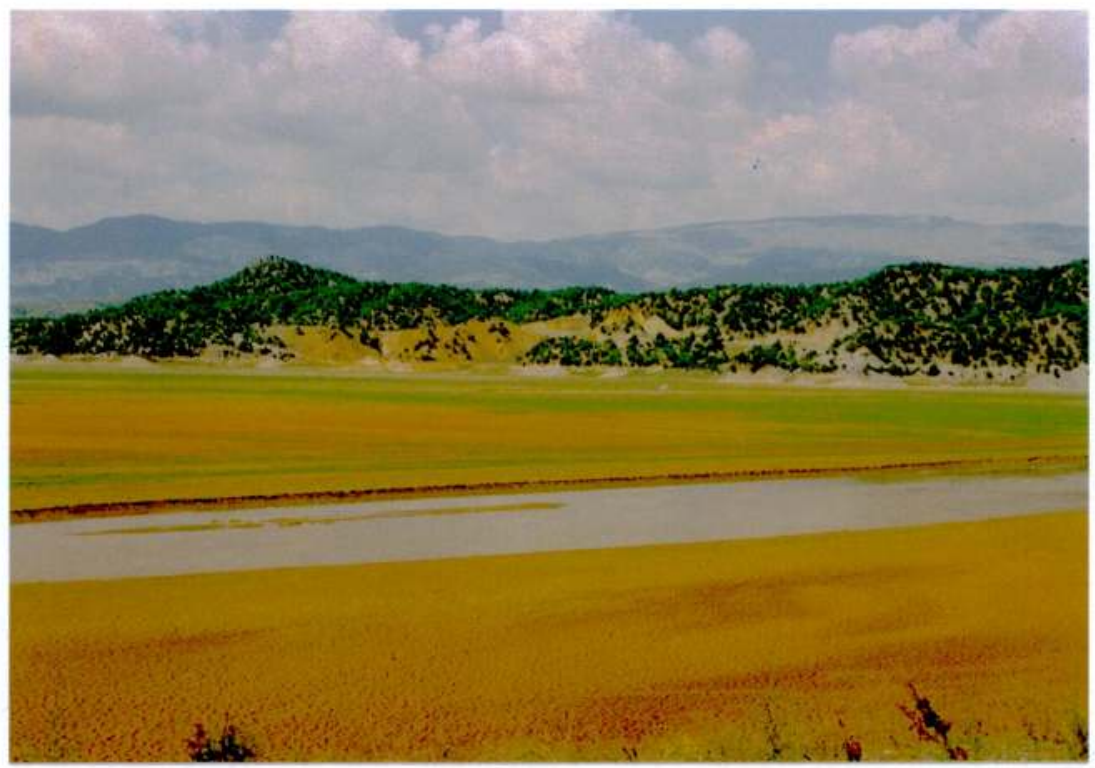

Resim 14: Sinop-Durağan, Kızılırmak Nehri ve Çayağzı Arsenik (Realgar ve Orpiment) Cevheri Yatağı, Güneydoğudan Genel Görünüm 


\section{Önder Bilgi}

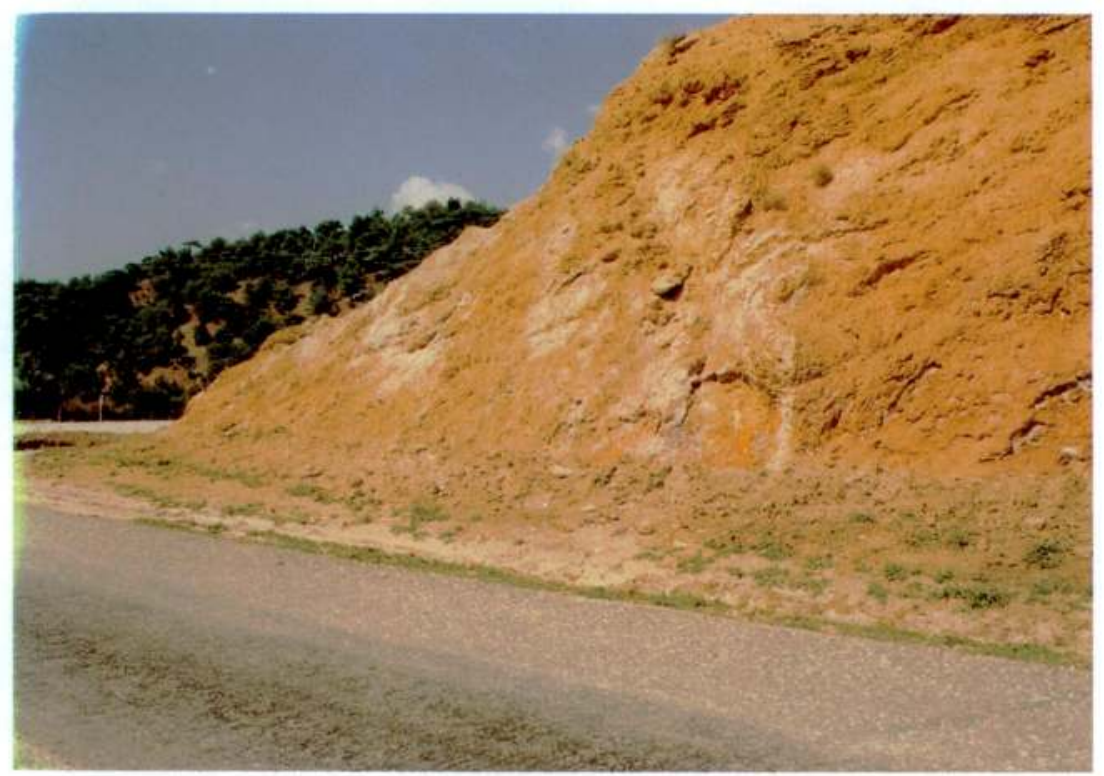

Resim 15: Çayağzı Arsenik (Realgar ve Orpiment) Cevheri Yatağı, Güneydoğudan

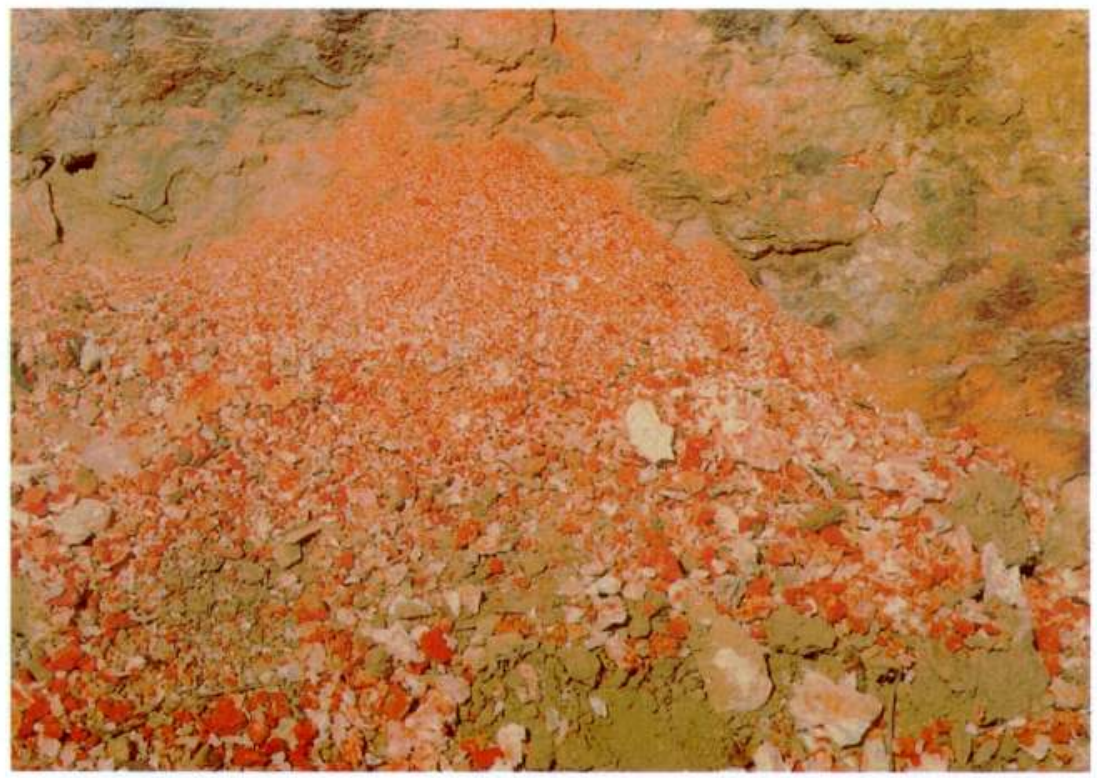

Resim 16: Çayağzı Realgar (arsenik + kūkürt) ve Orpiment (arsenik + kủkūrt) Cevheri Yatağı 
Önder Bilgi

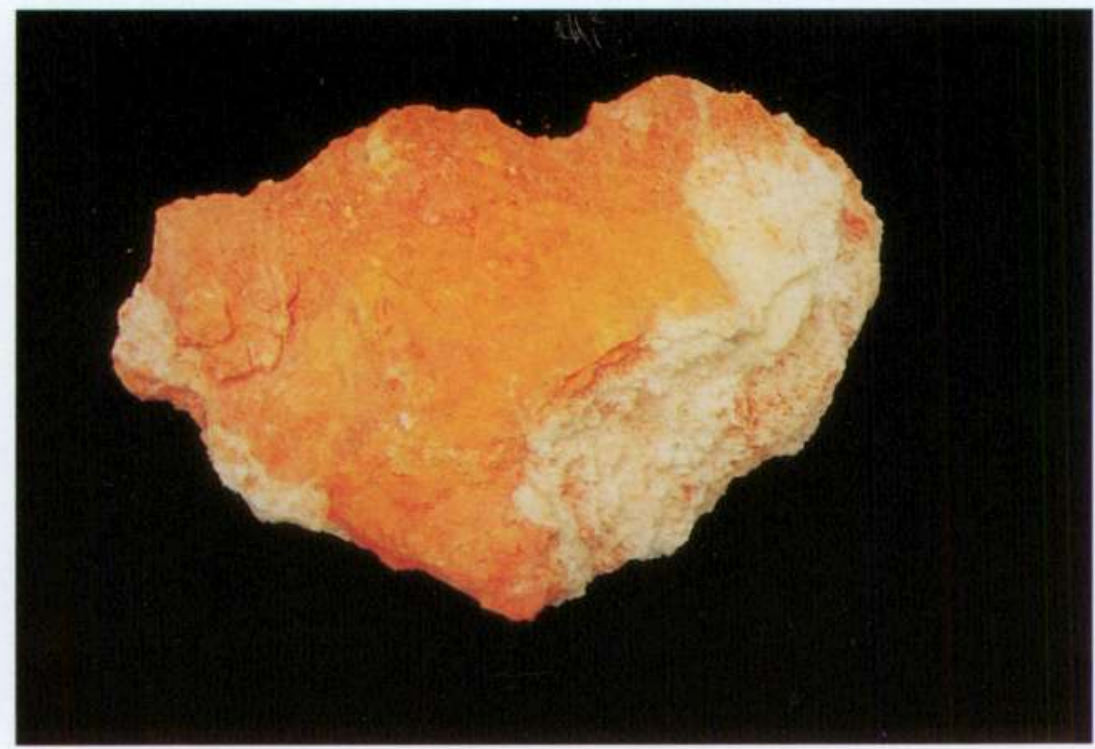

Resim 17: Realgar (arsenik + kükürt) Cevheri Ōrneği

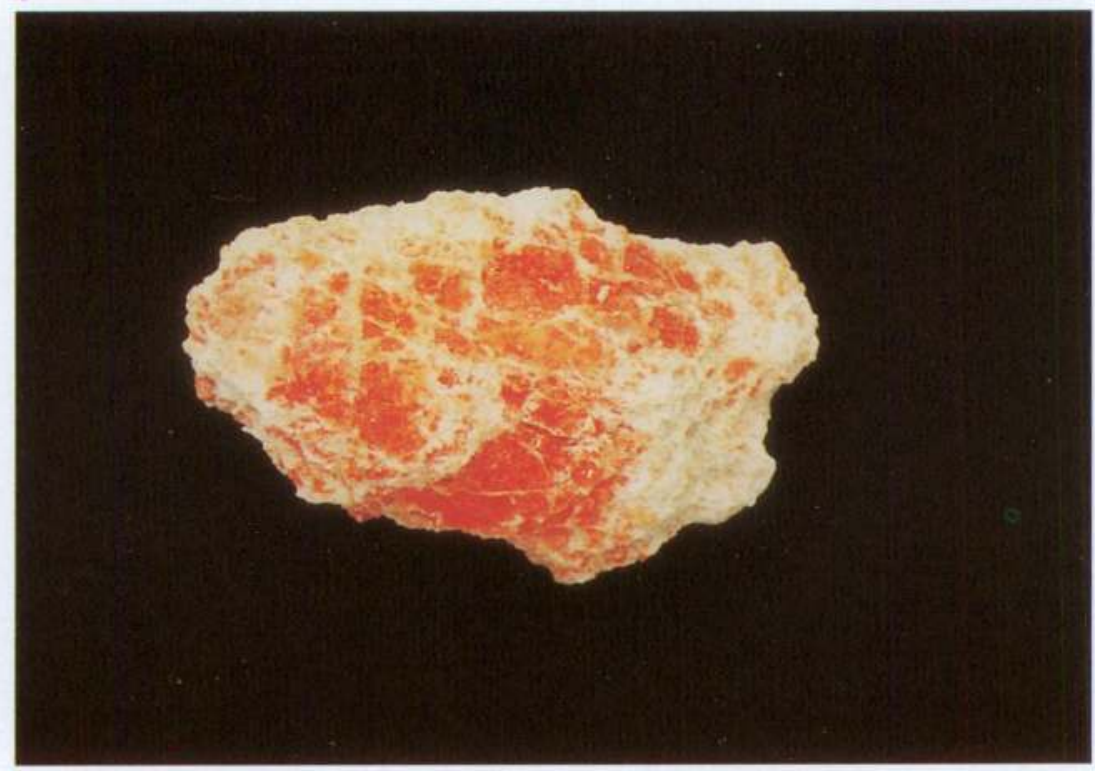

Resim 18: Orpiment (arsenik + kükūrt) Cevheri Örneği 


\section{Önder Bilgi}

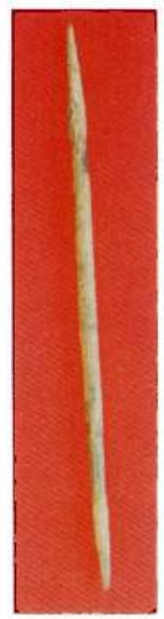

19

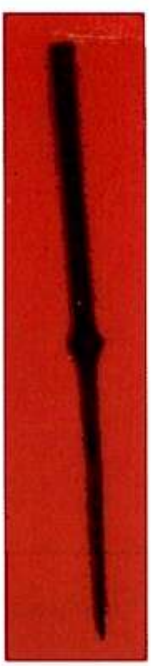

20

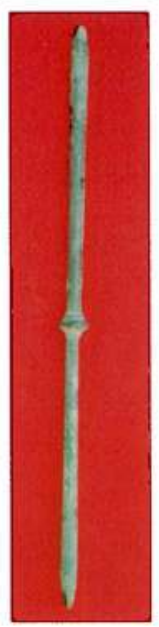

21

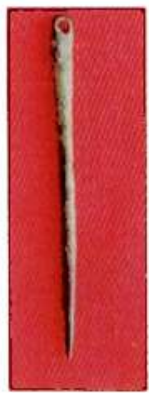

22

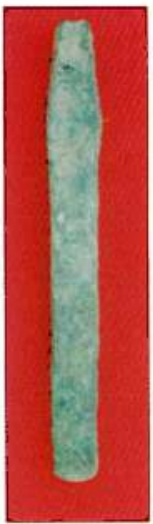

23

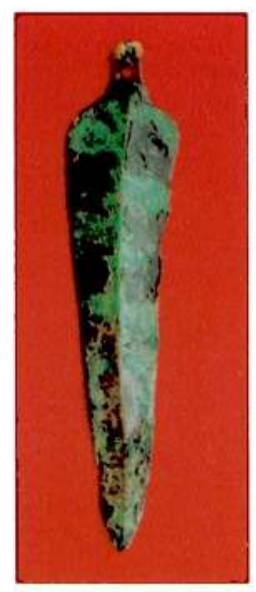

24

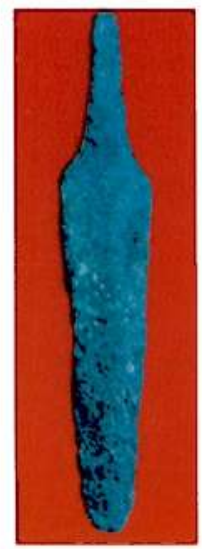

25

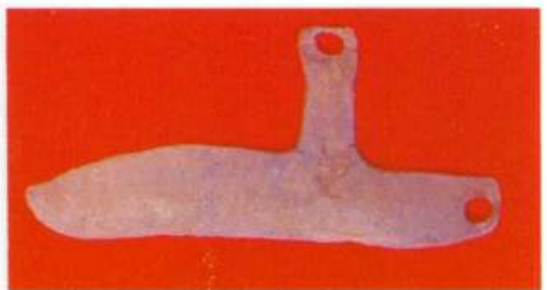

26 
Önder Bilgi

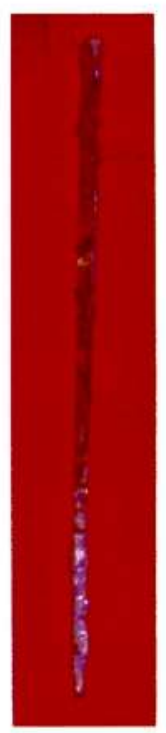

27

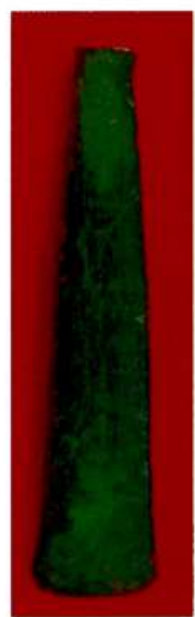

30

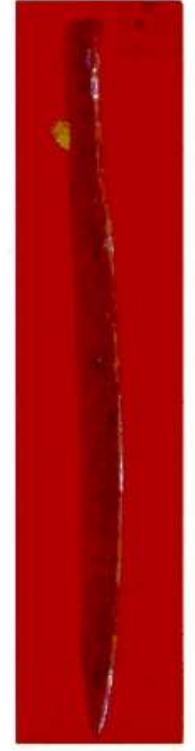

28

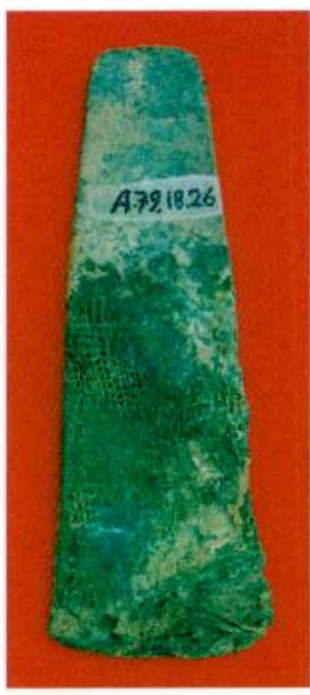

29

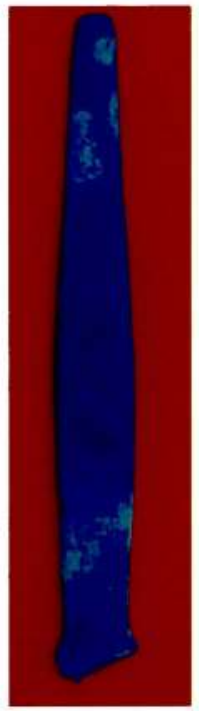

31

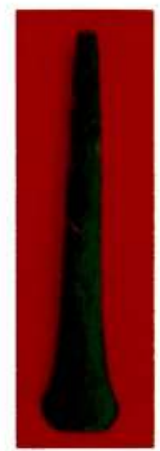

32

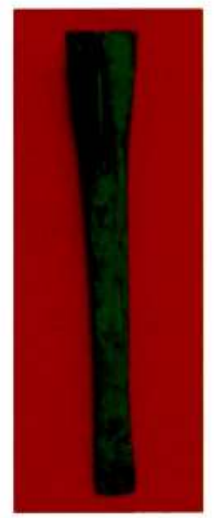

33 


\section{Önder Bilgi}

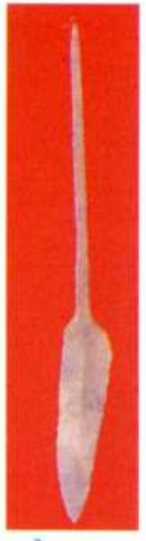

34

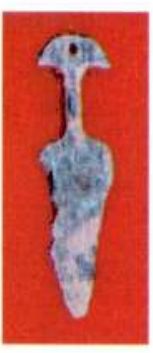

35

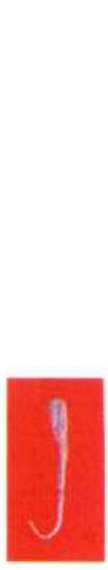

36

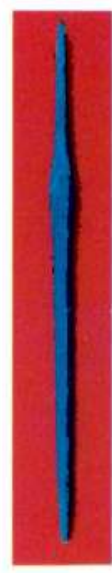

37

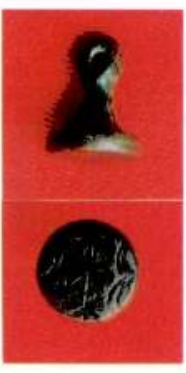

38

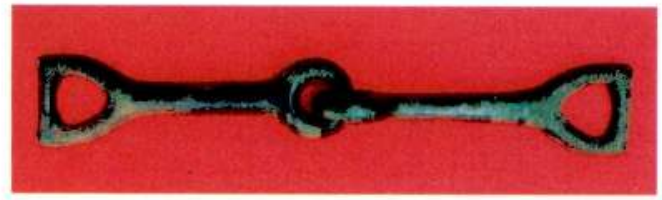

39

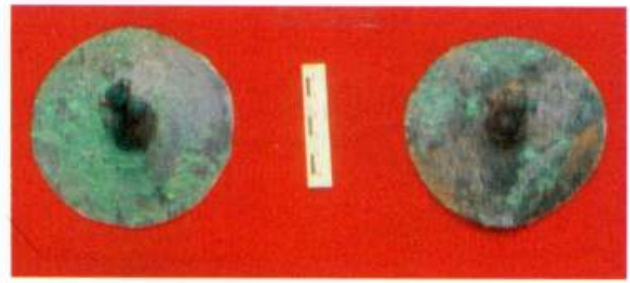

40

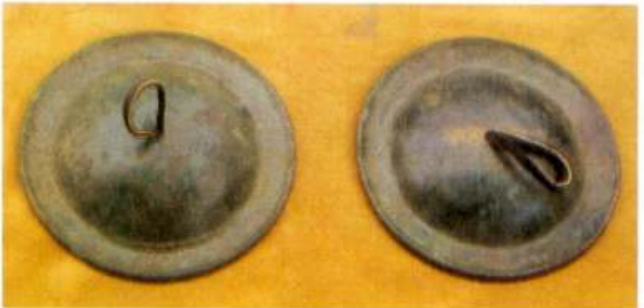

41 
Önder Bilgi

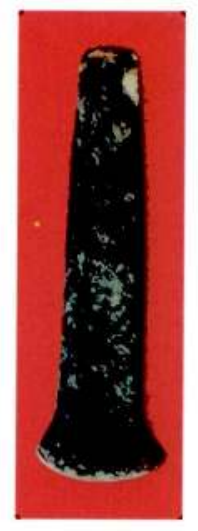

42

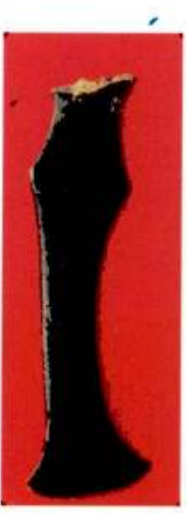

46

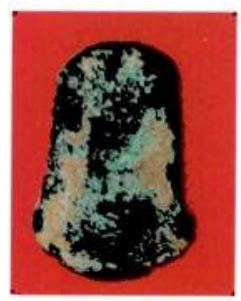

43

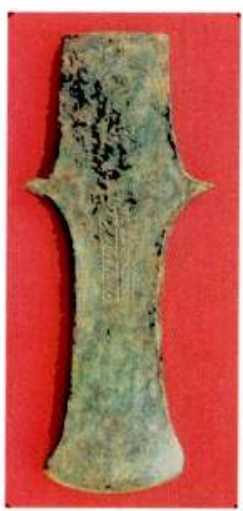

47

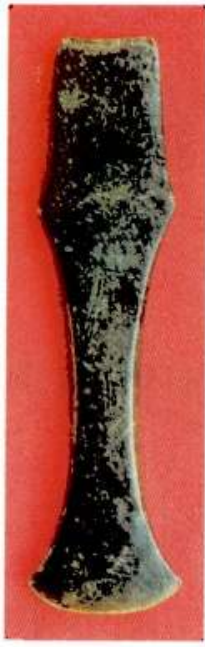

4

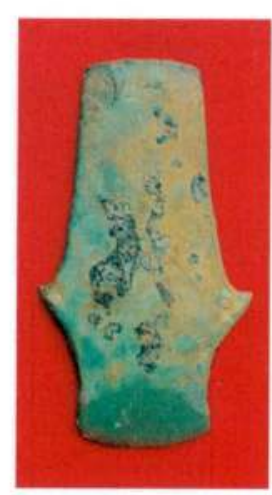

48

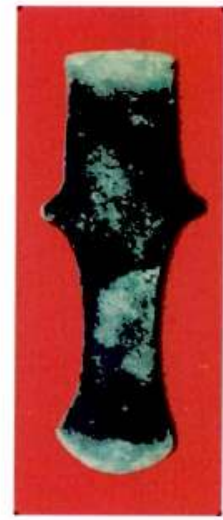

45

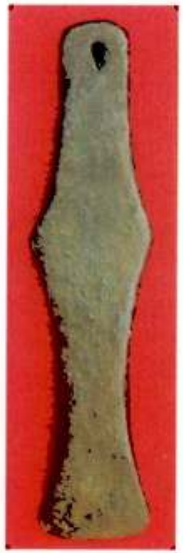

49 
Önder Bilgi

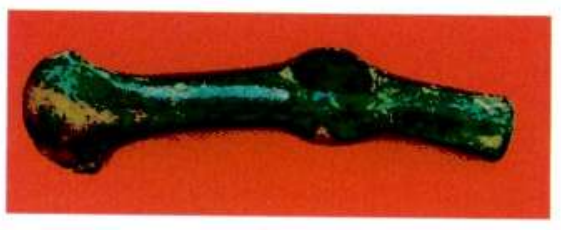

50

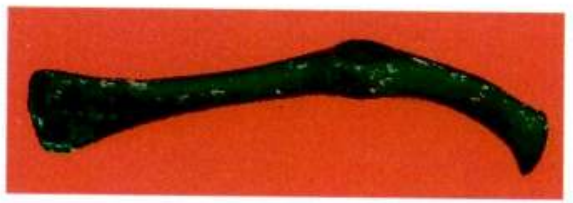

51

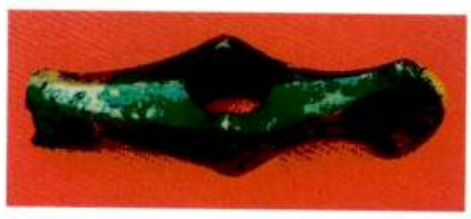

52

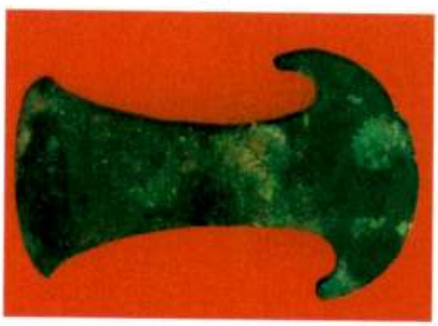

53

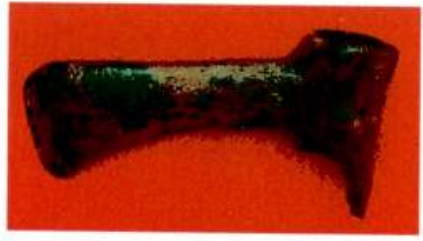

54 


\section{Önder Bilgi}

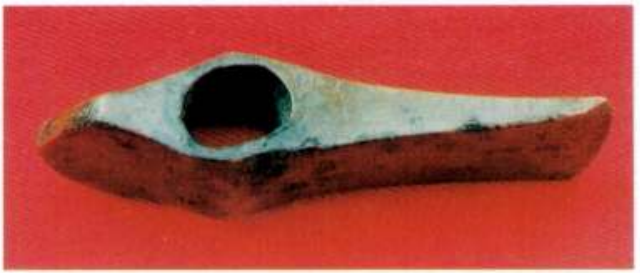

55

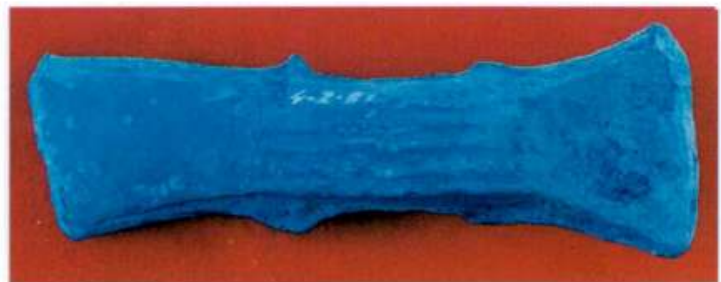

56

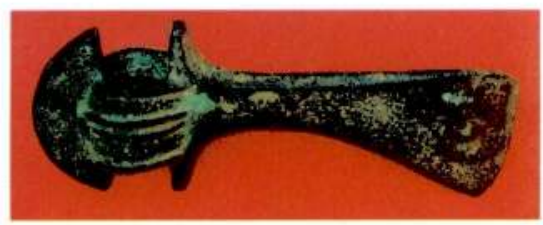

57

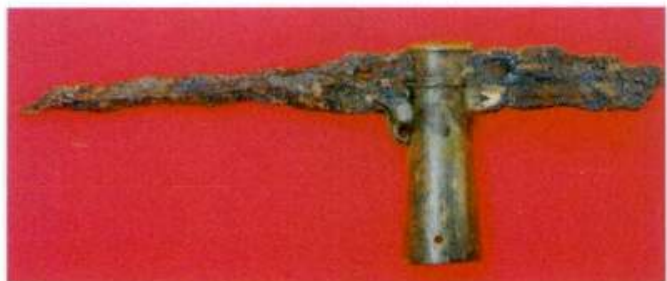

58

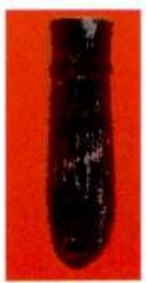


Önder Bilgi

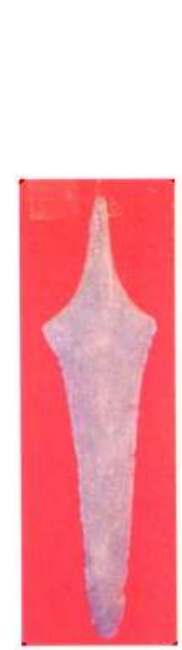

59

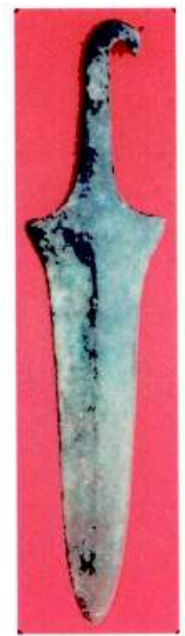

60

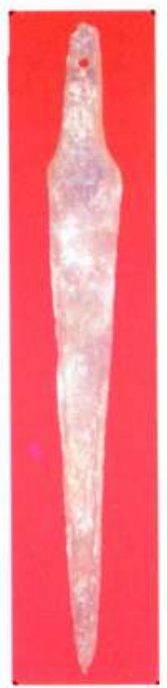

61

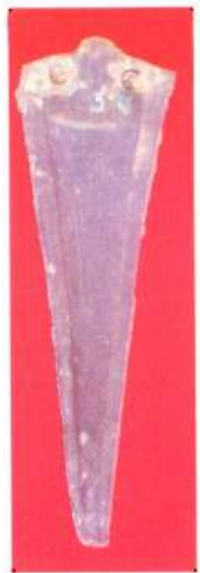

62

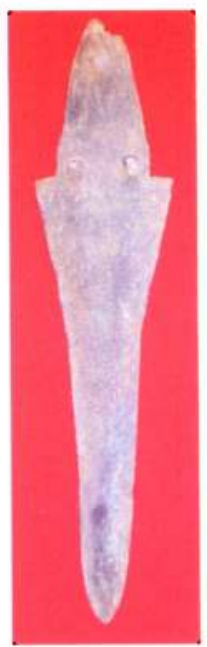

6.3

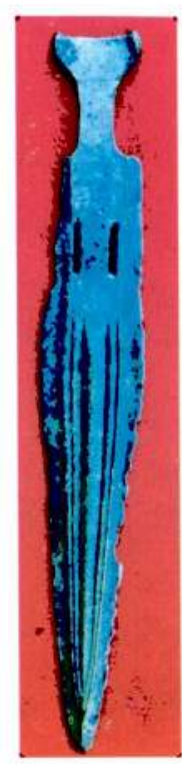

64

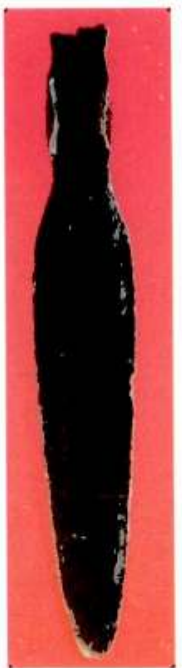

65

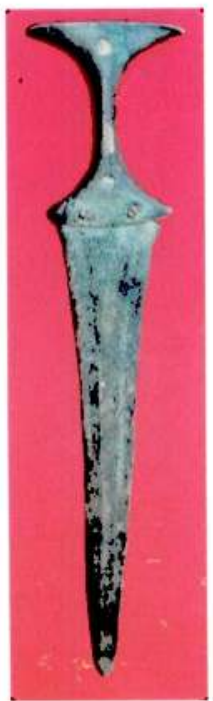

66 


\section{Önder Bilgi}

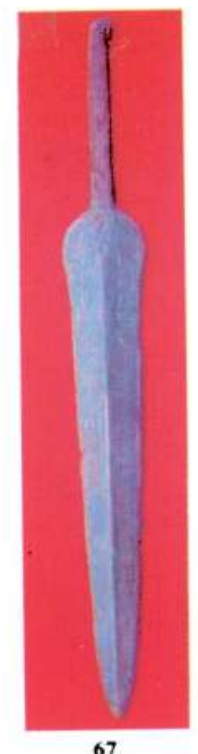

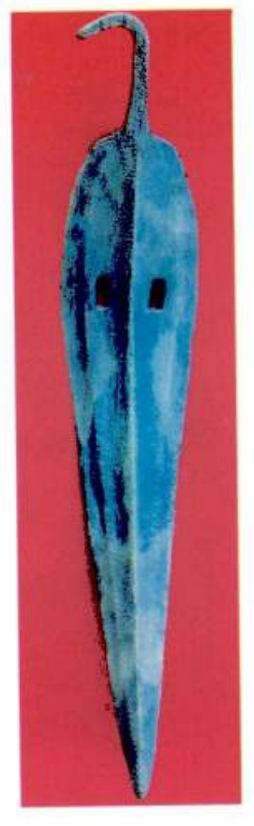

68

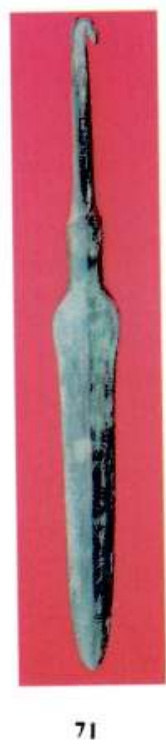

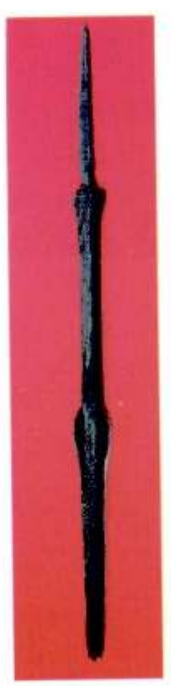

72
71

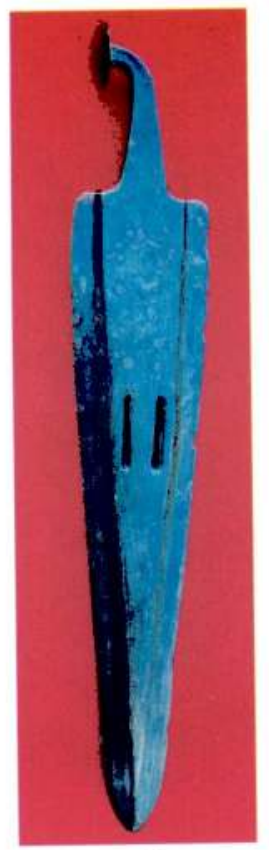

69

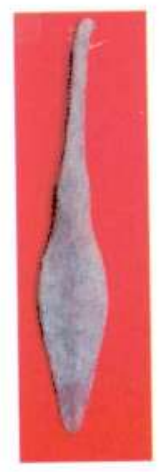

70

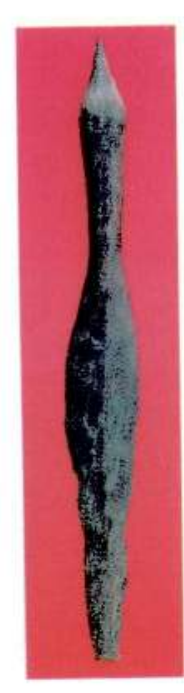

73

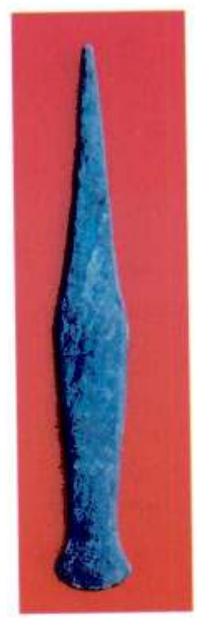

74 


\section{Önder Bilgi}

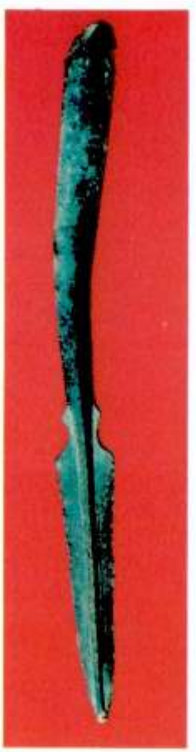

75

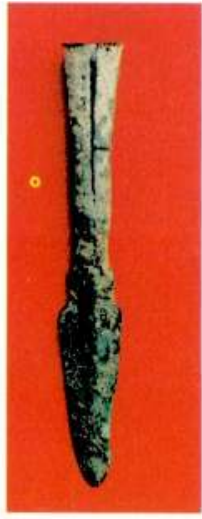

76

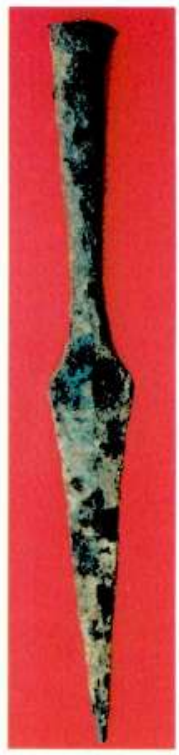

77

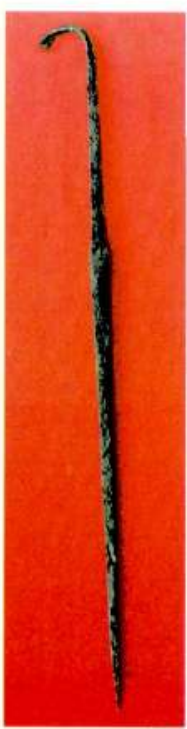

78

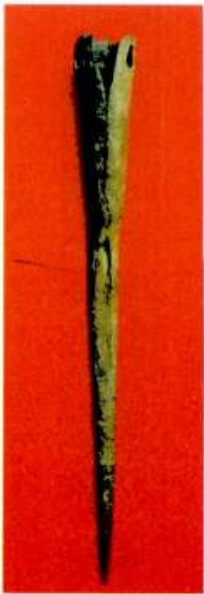

79 
Önder Bilgi

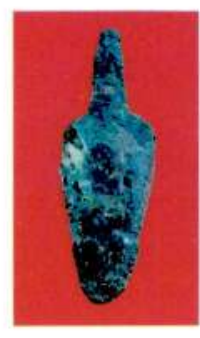

81

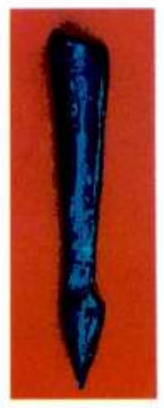

85

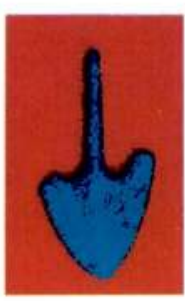

81

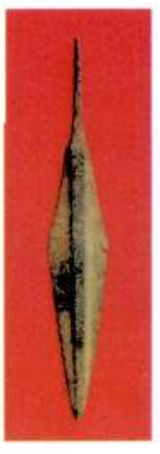

$x 2$

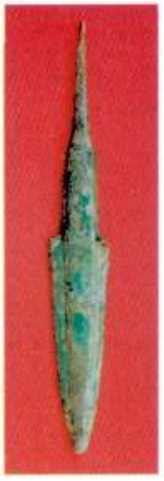

8.3

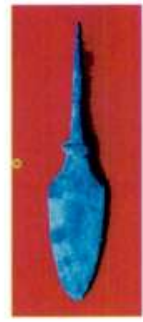

$x-4$

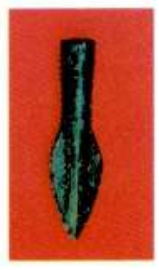

86

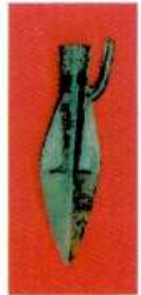

87

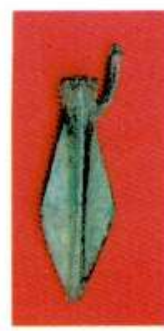

xx

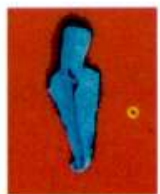

89

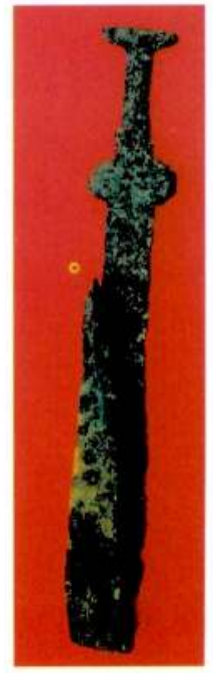

90 


\section{Önder Bilgi}

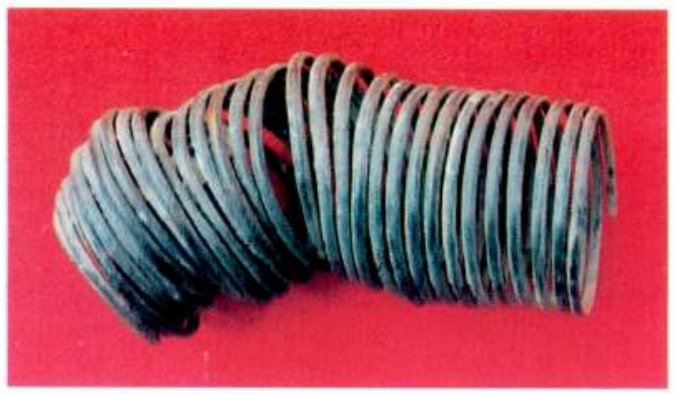

91

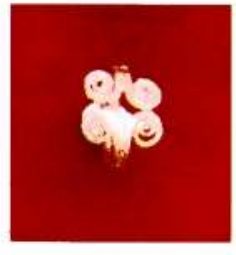

92

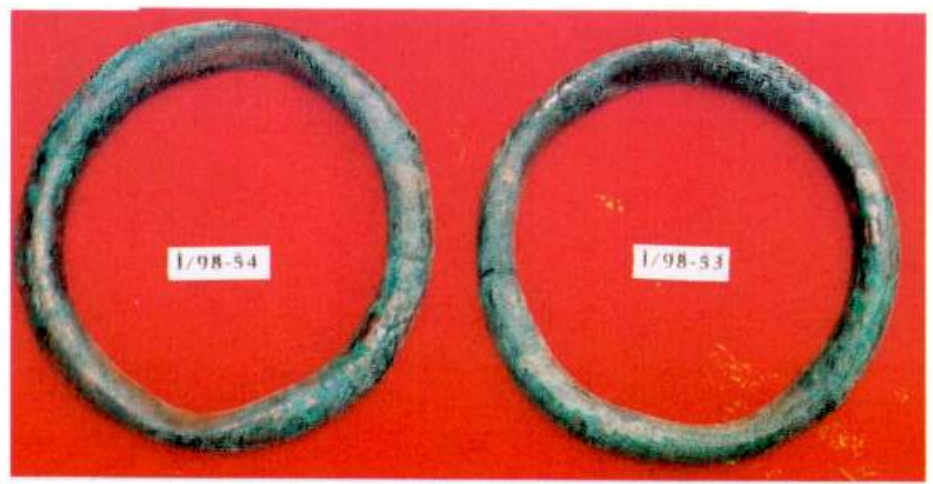

93 
Önder Bilgi

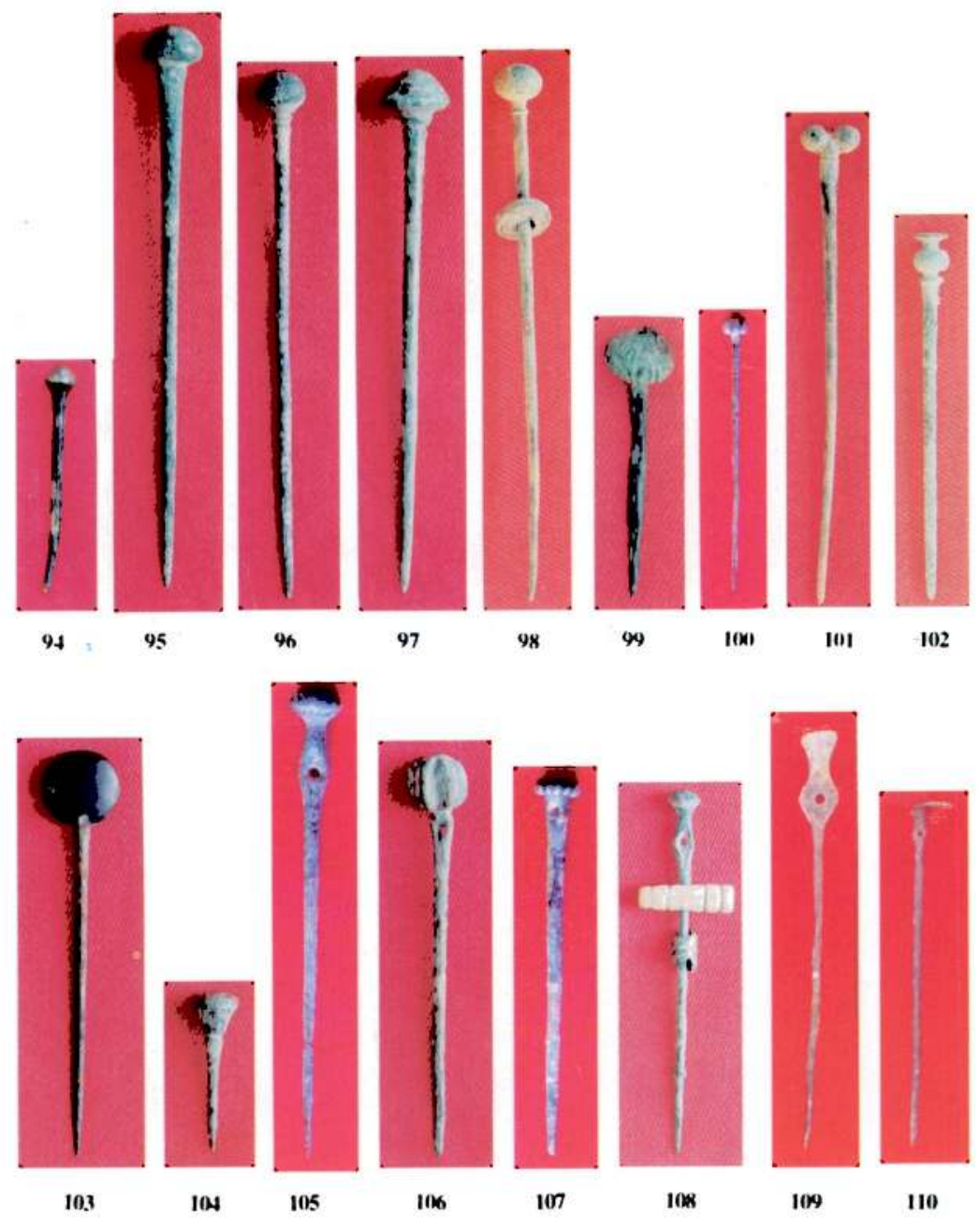


Önder Bilgi

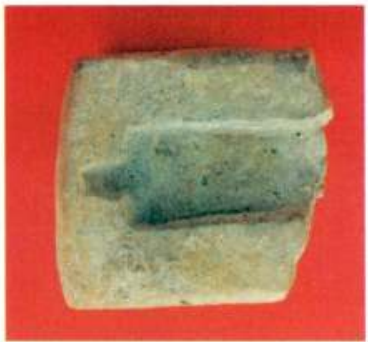

111

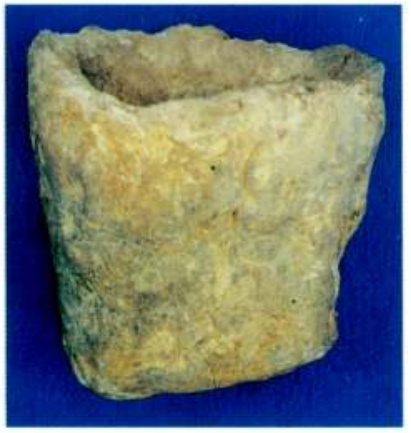

11.3

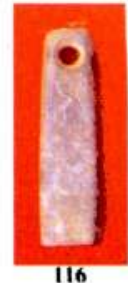

116

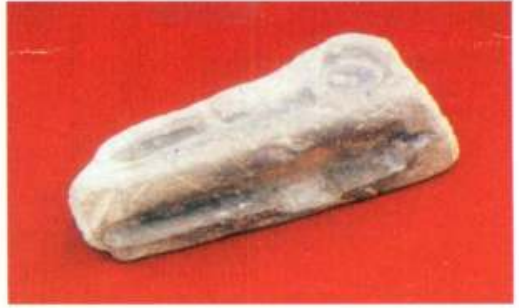

112

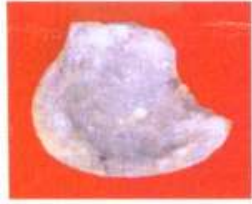

114

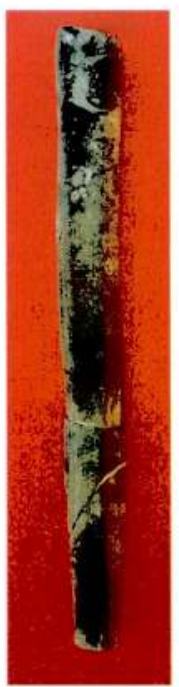

117
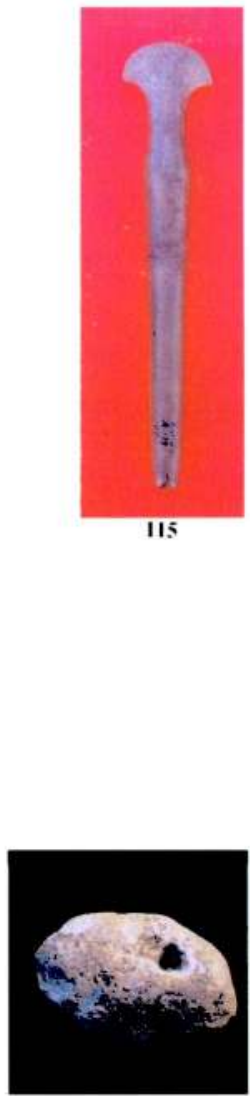

118 
Önder Bilgi
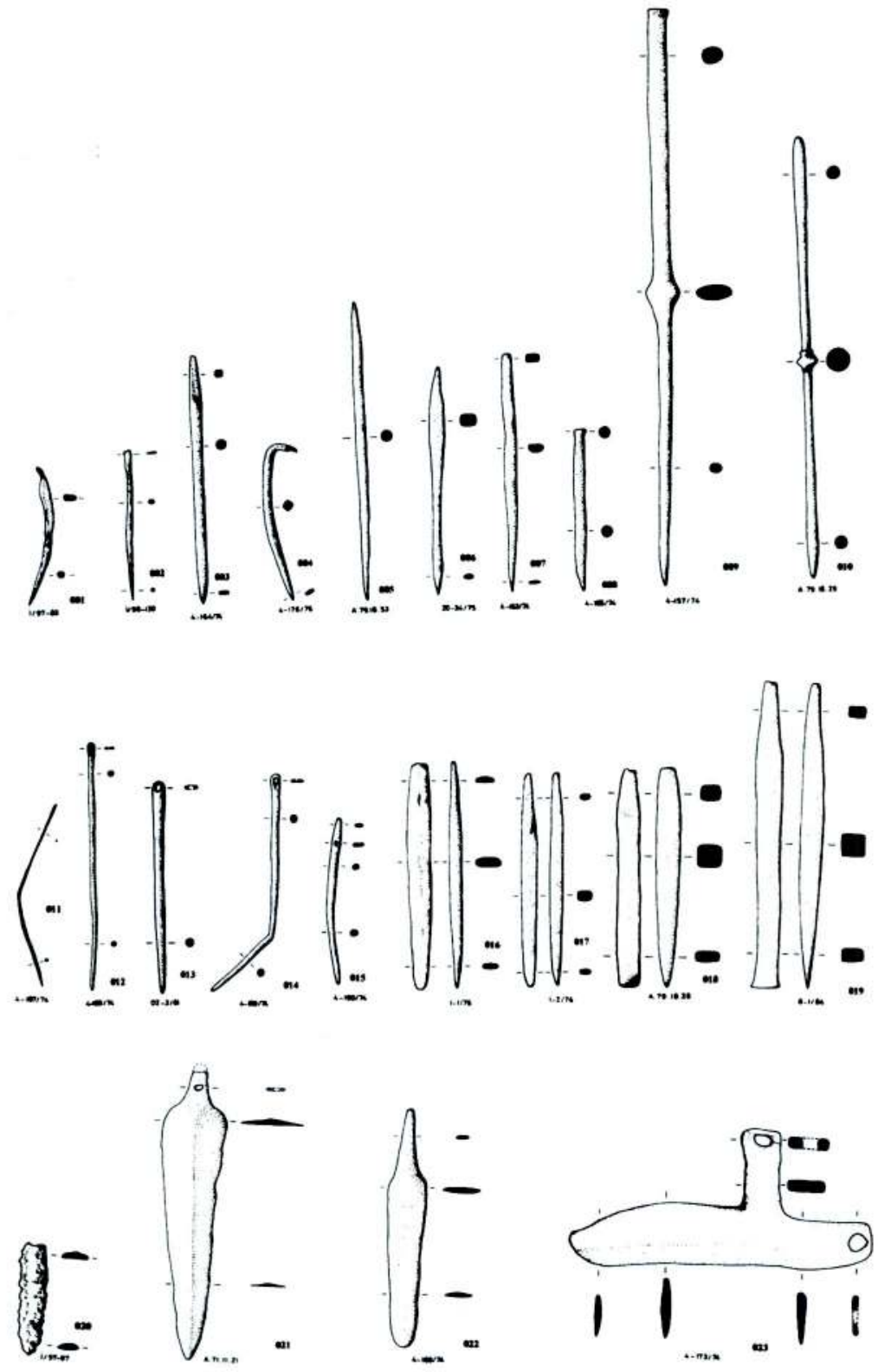

Table 1

ALETLER: Deticiter Sek, I ve 2-TTC II, 3-ITC III, 4-10-0TC; Ditis Itmeleri Sek 11-15-0TC: Kelemiler Selk. 16-19-0TC; Kesiciler Sek, 20-ITC n1, 21-ITC III, 22-23-0TC 


\section{Önder Bilgi}
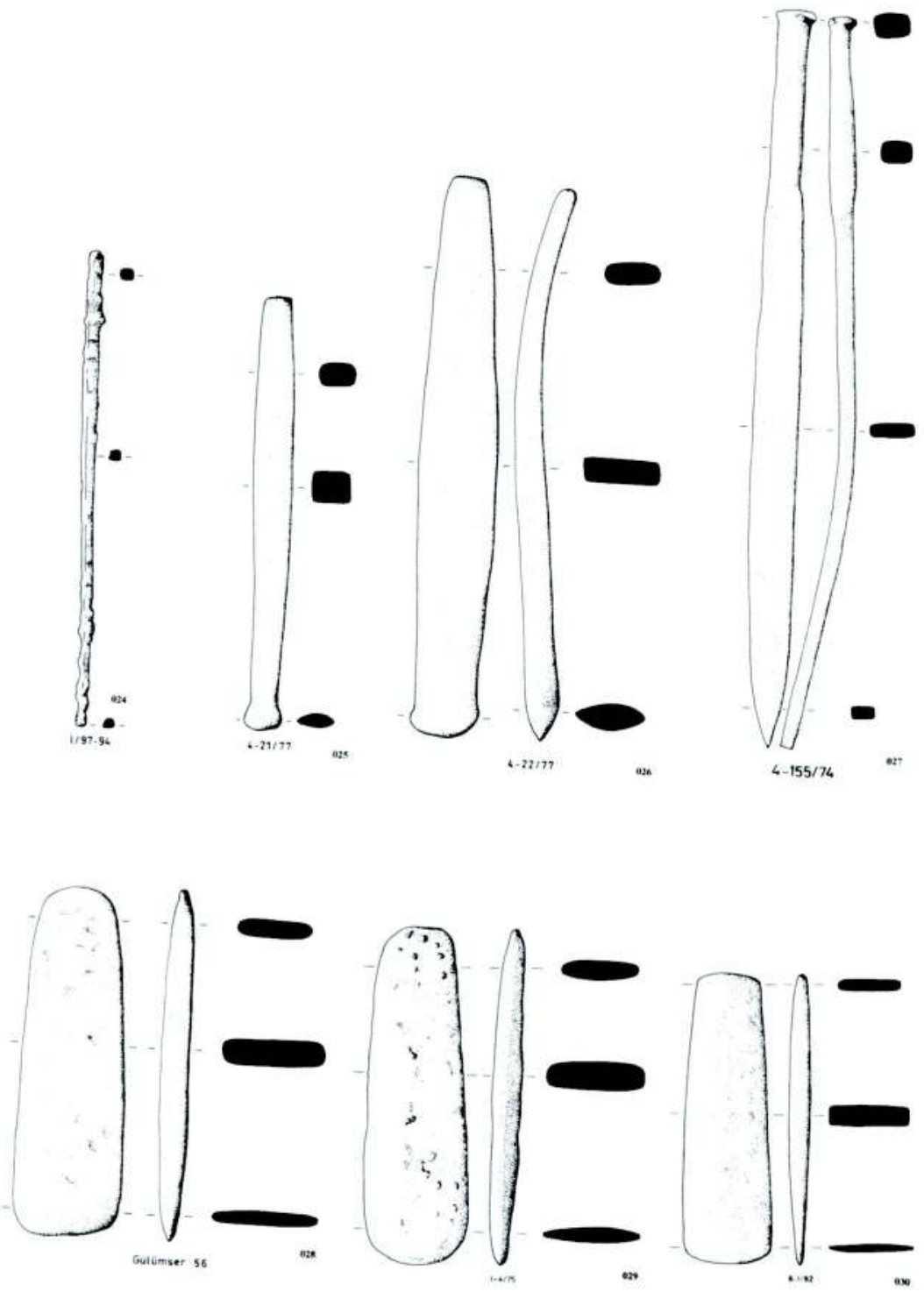

Table 2

ALETLER: Keskiler Șek. 24=ITC II, 25-26=iTC III, 27-OTC, 28-30=ITC III 


\section{Önder Bilgi}
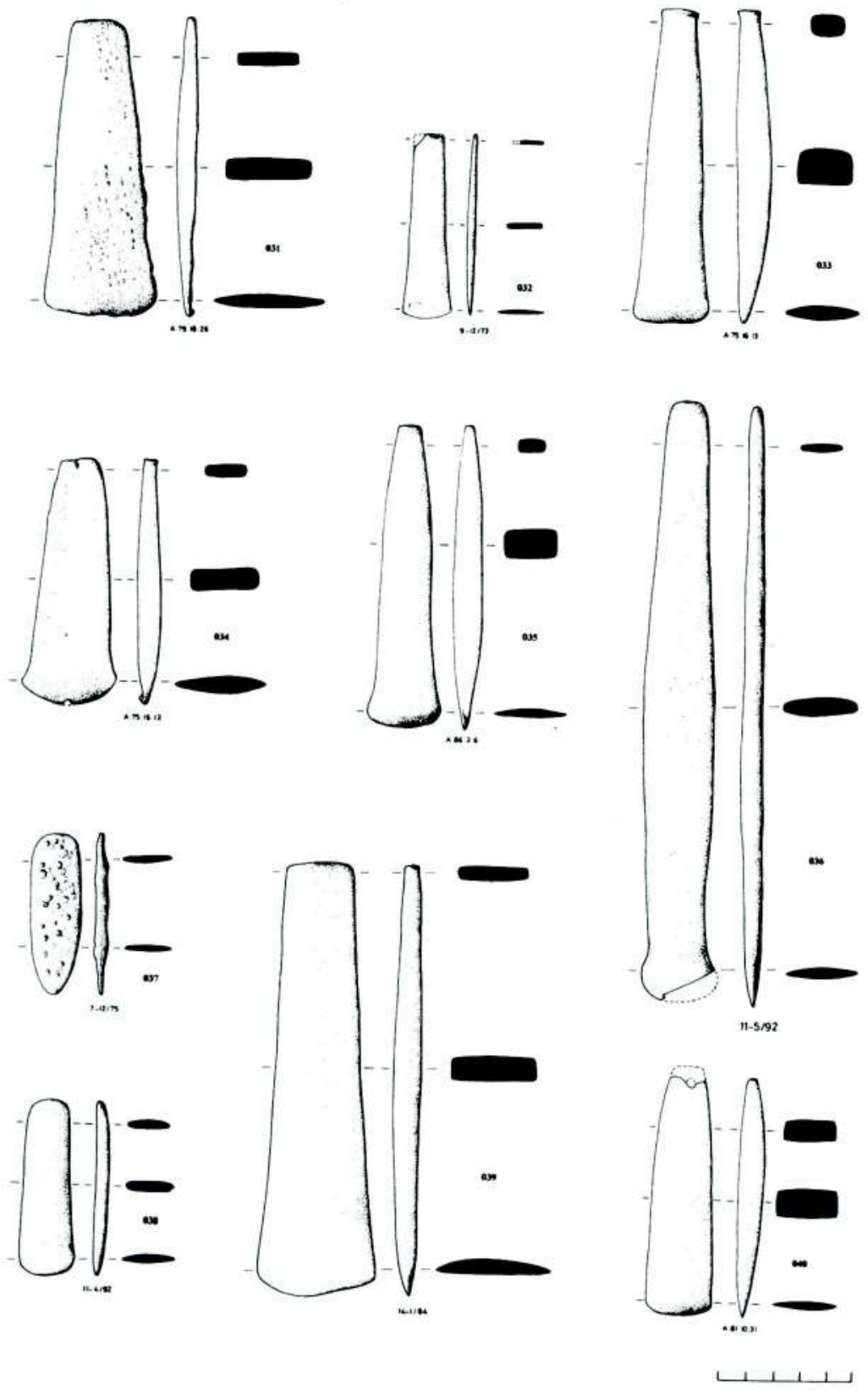

Tablo 3

ALETLER: Keskiler Sek. 31-36=ITC III, 37-40-OTC 

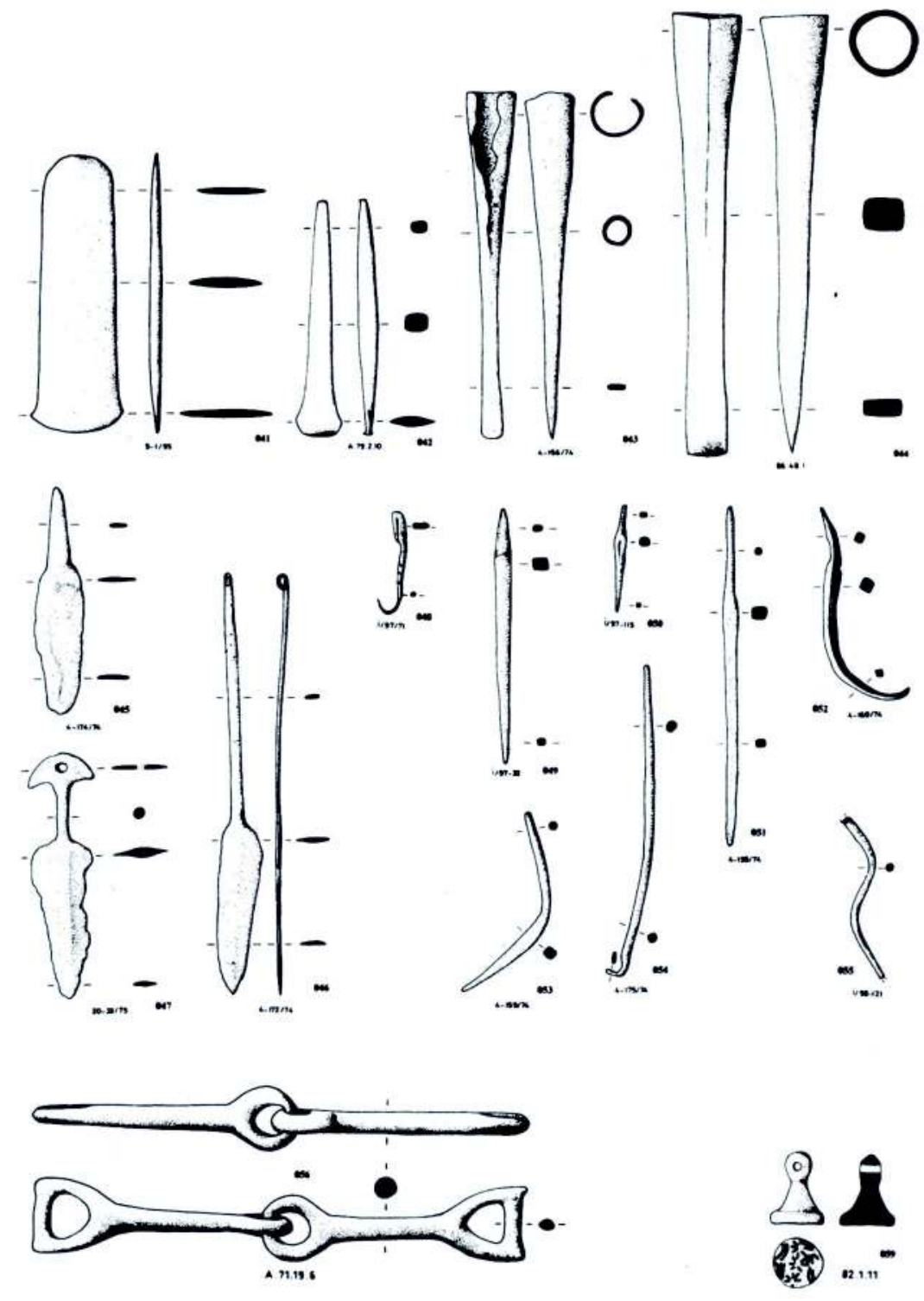

Tablo 4

ALETLER: Keskiler Sekt 41-44-0TC; Usturalar Sek, 45-46-ITC III, 47-0TC; Ota Itmesi Setk 40=1TC II; Zipkinuclari Setk 49-50-ITC II, 51-53-ITC III; Tit Set. 54-ITC III; Tet Set. 55=ITC II; Gem Sek. S6=GDC; Marar Sek.59=0TC 
Önder Bilgi
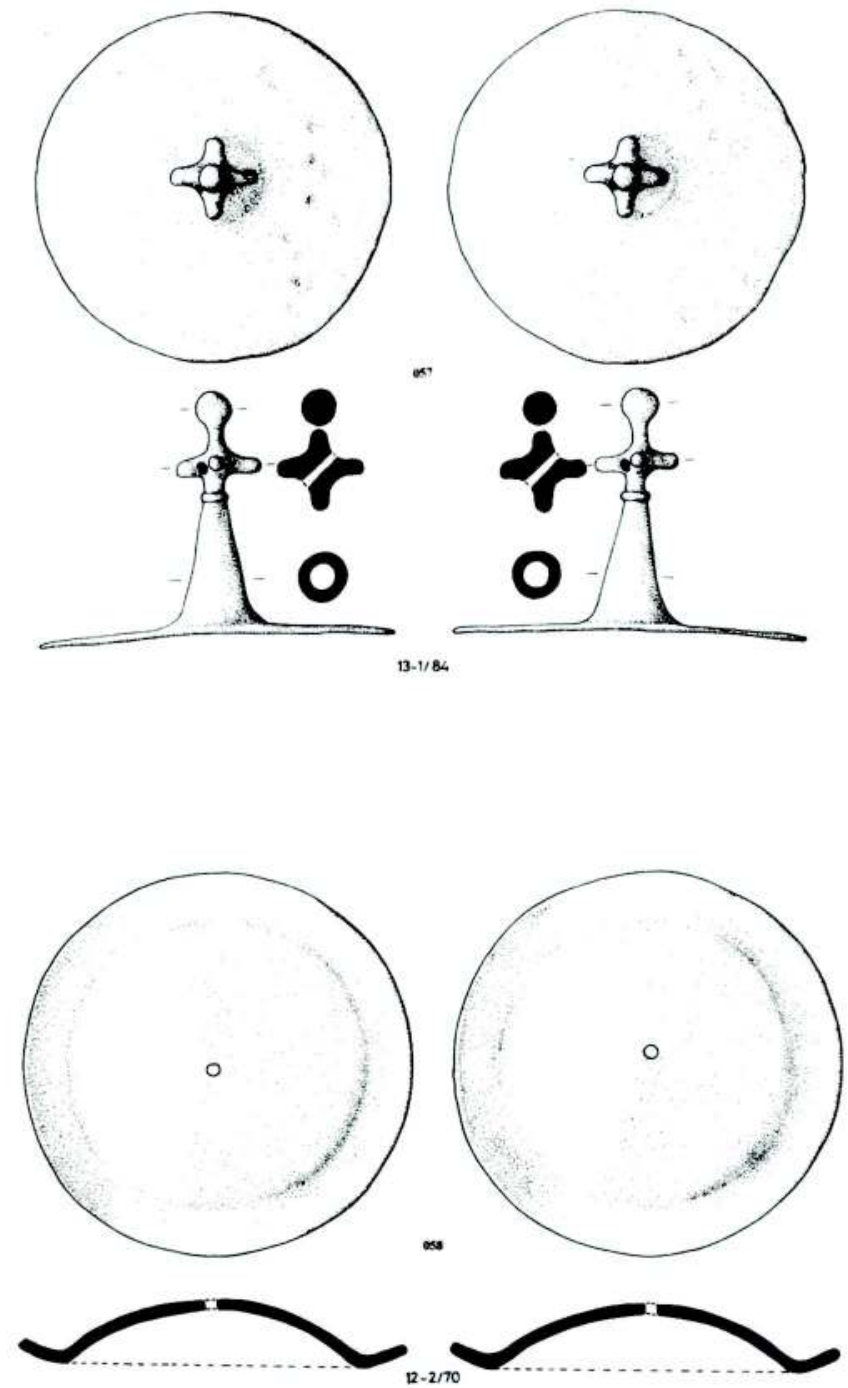
Önder Bilgi
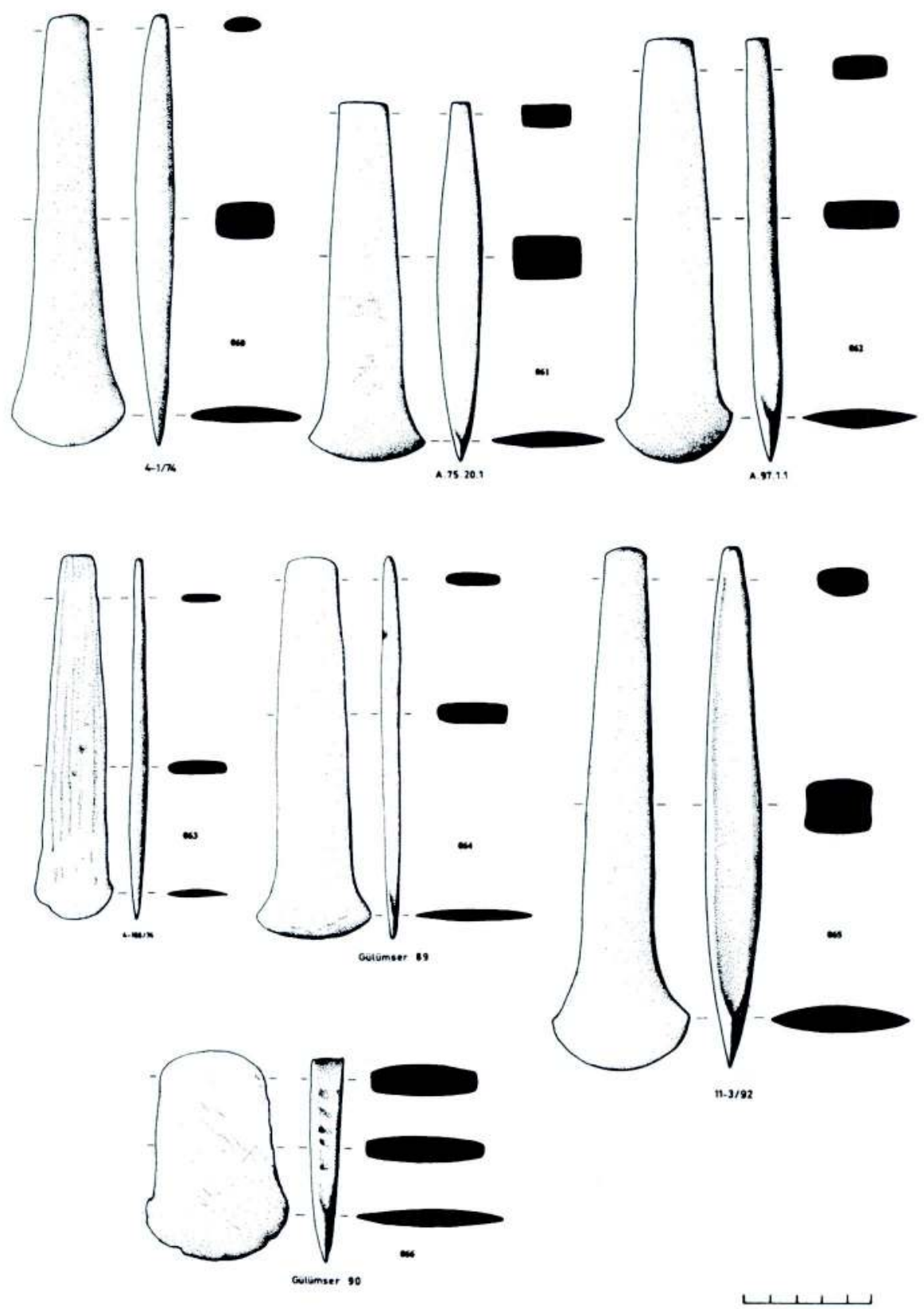

Tablo 6

StLAHLAR: Yass Batealar Sek, 60-62=ITC III, 63-66=0TC 
Önder Bilgi
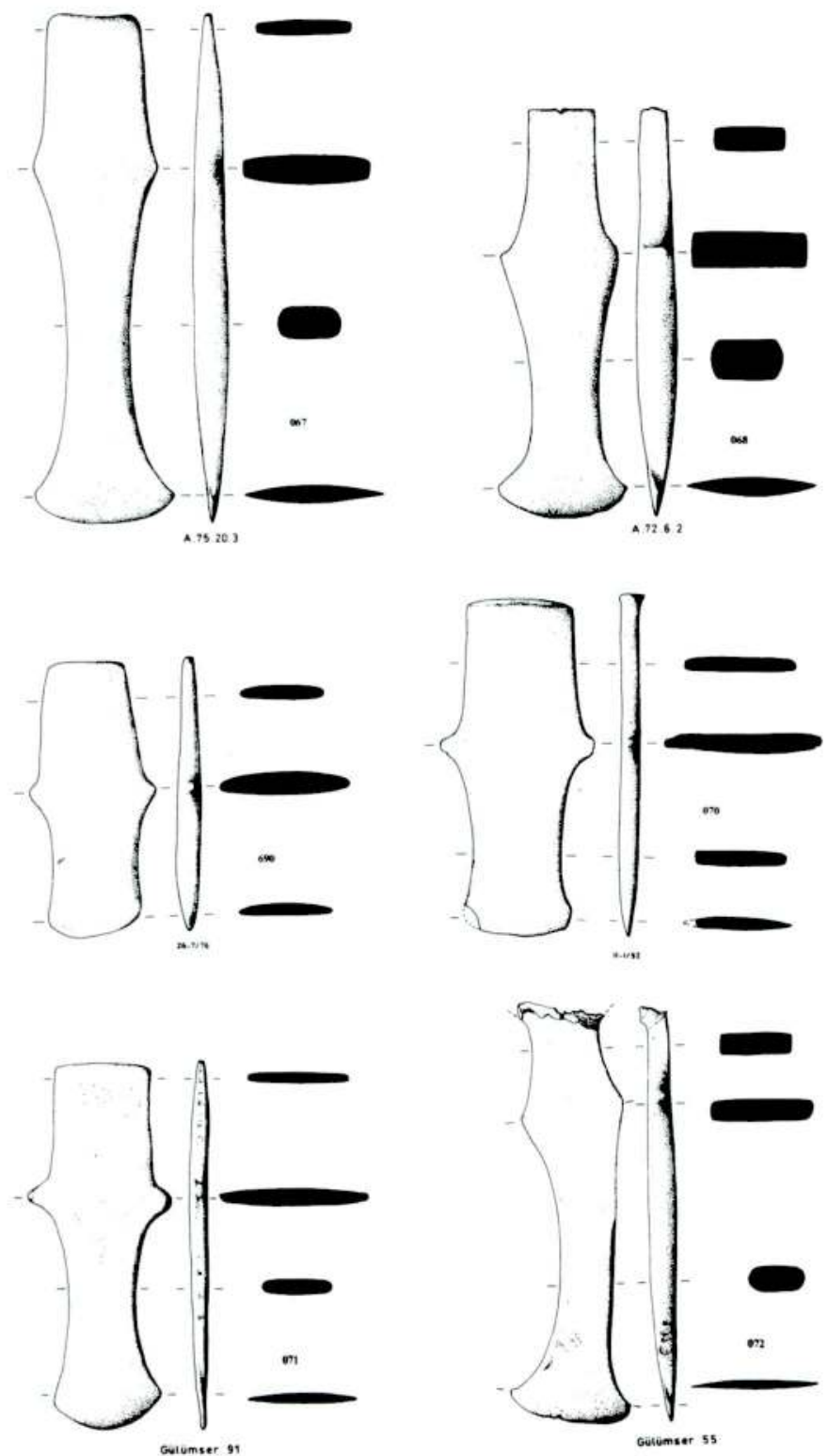

Tablo 7 StLAHLAR: Kolcuklu Baltalar Sek. 67-72=OTC 


\section{Önder Bilgi}
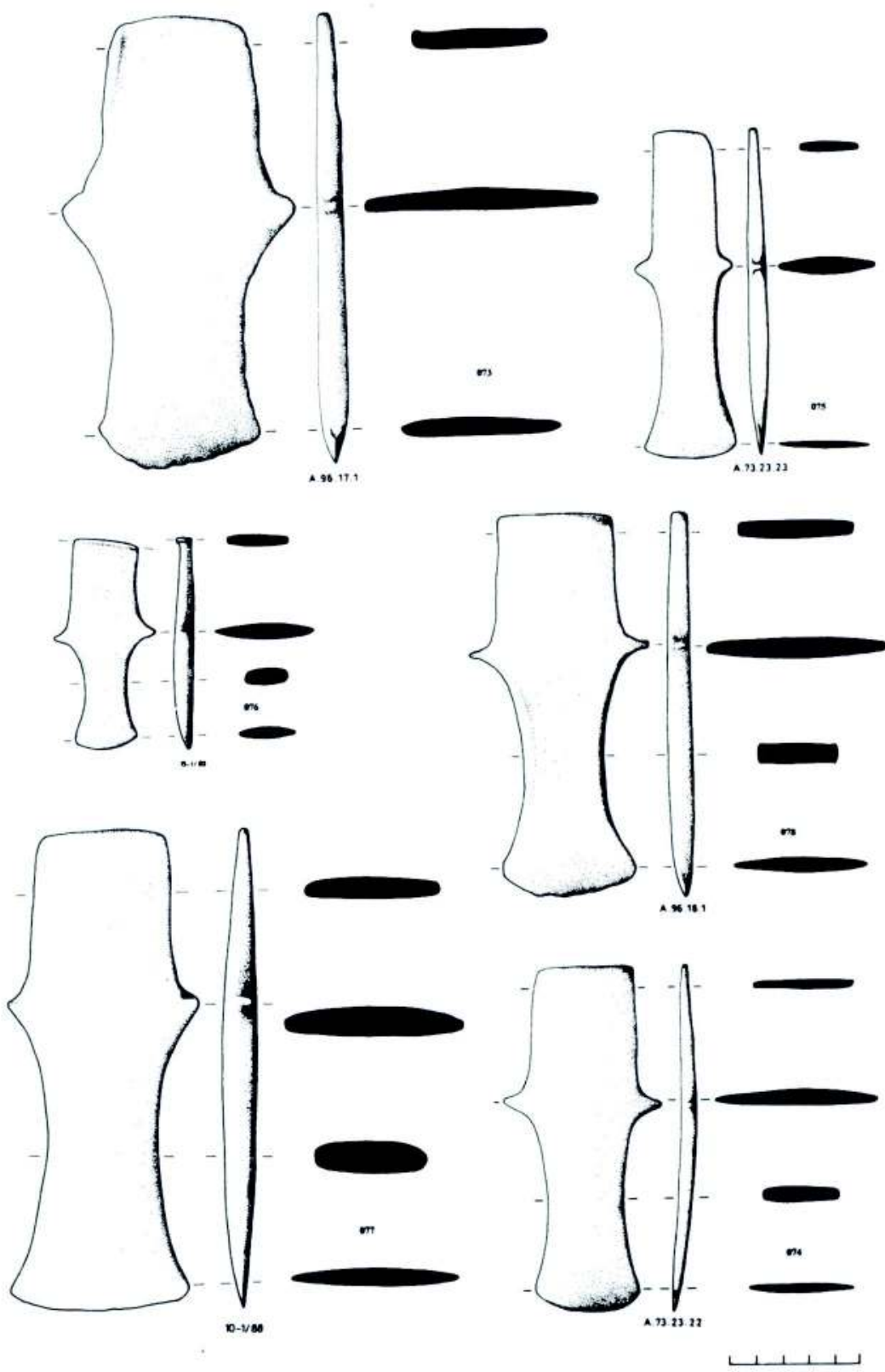

Tablo 8 SILAHLAR: Kolcuklu Battaiar Șek. 73-78=GTC 
Önder Bilgi
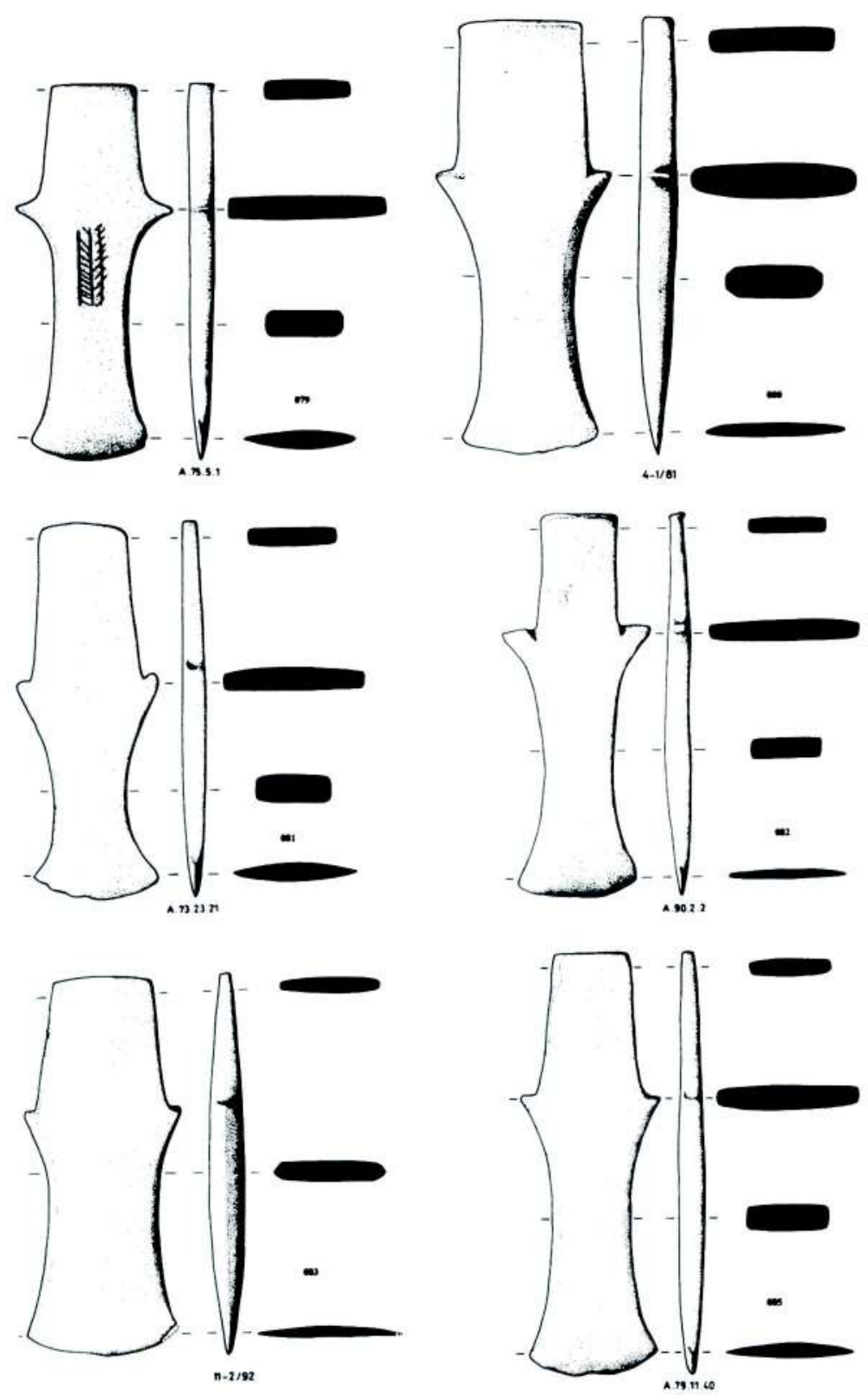

Tablo 9 SiL_AHLAR: Kolcuklu Baltainr Sek. 79-84=GTC 


\section{Önder Bilgi}
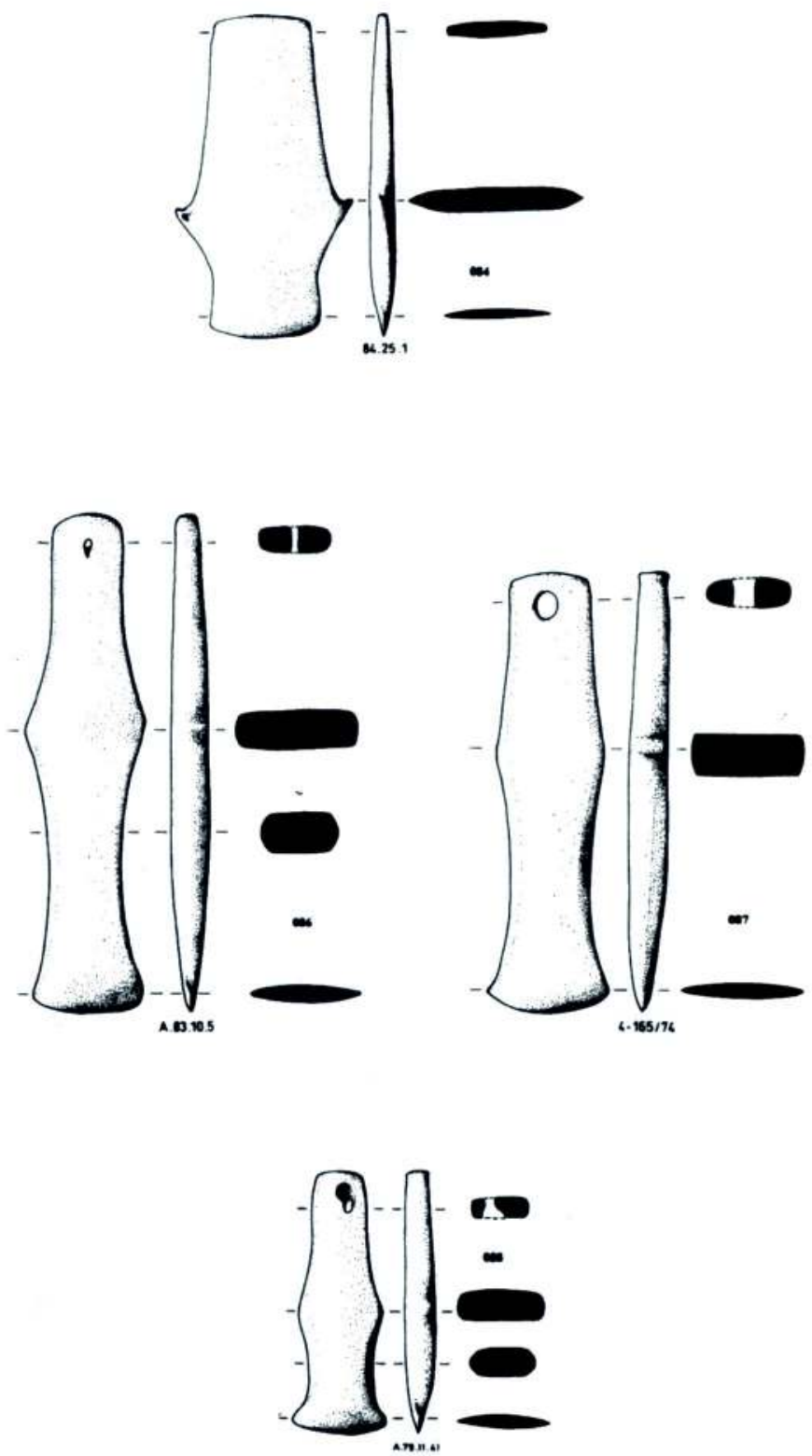

Tablo 10

SHLAHLAR: Kolcuktu Balkelar Sek 85-GTC, 26-80-0TC 

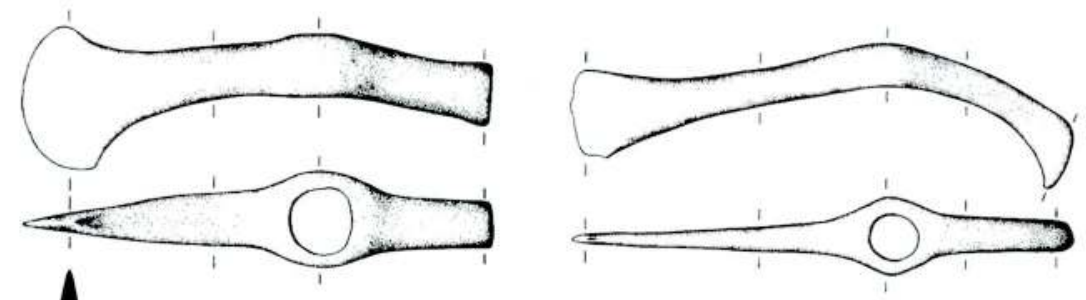

ans
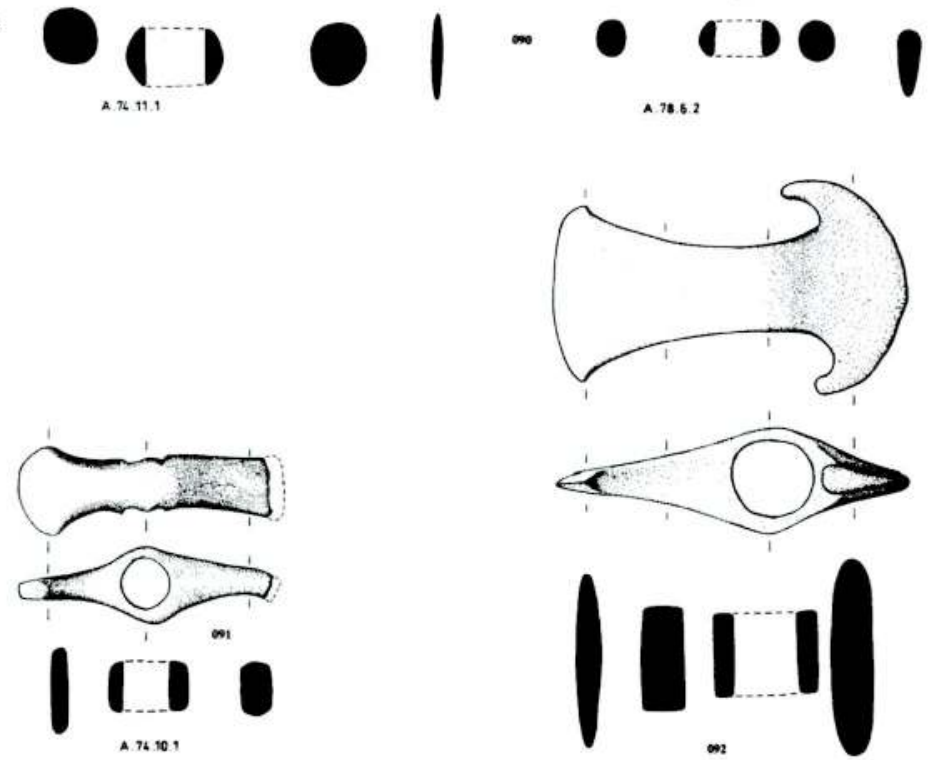

Lay 2

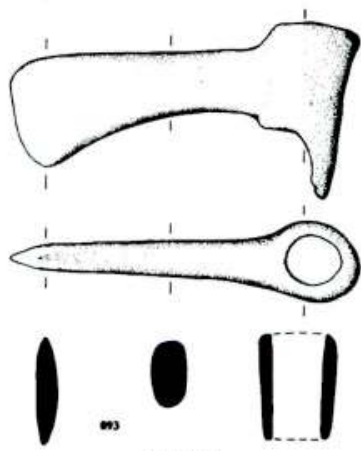

A. 73.2326

Tablo 11

StLAHLAR: Sap Delikci Behalar Seke 89-93-ITC III, 


\section{Önder Bilgi}
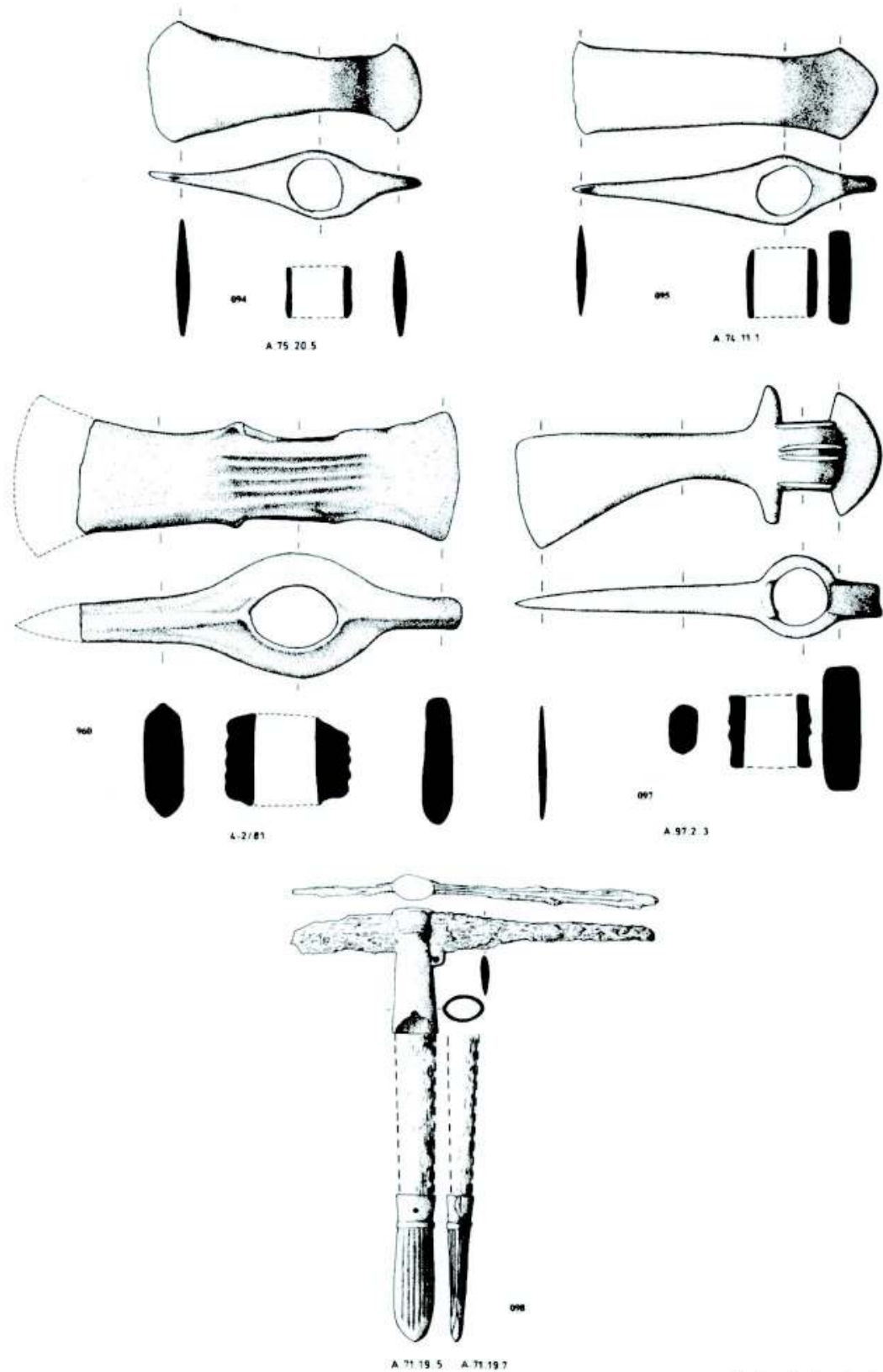

Tublo 12 
Önder Bilgi
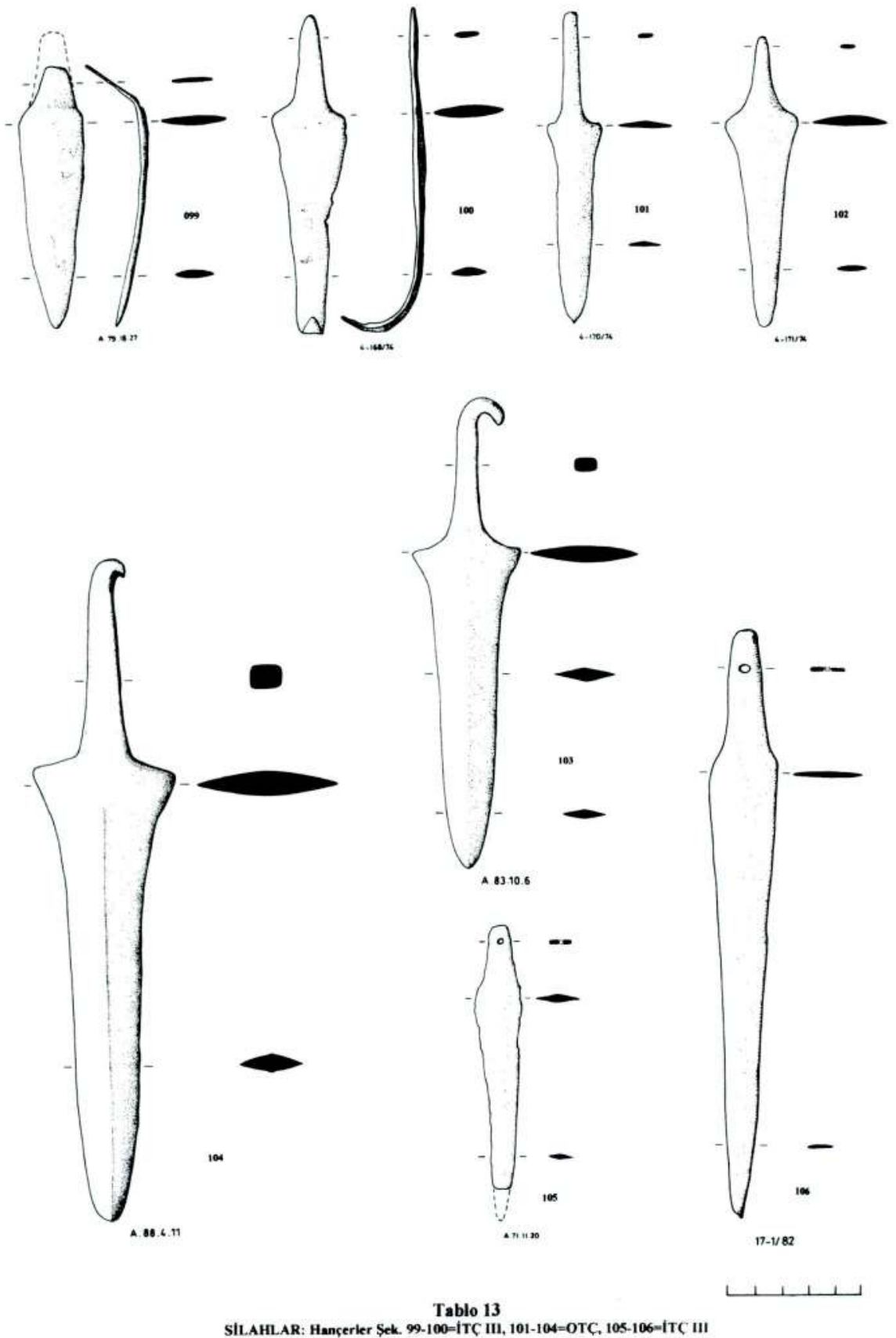
Önder Bilgi
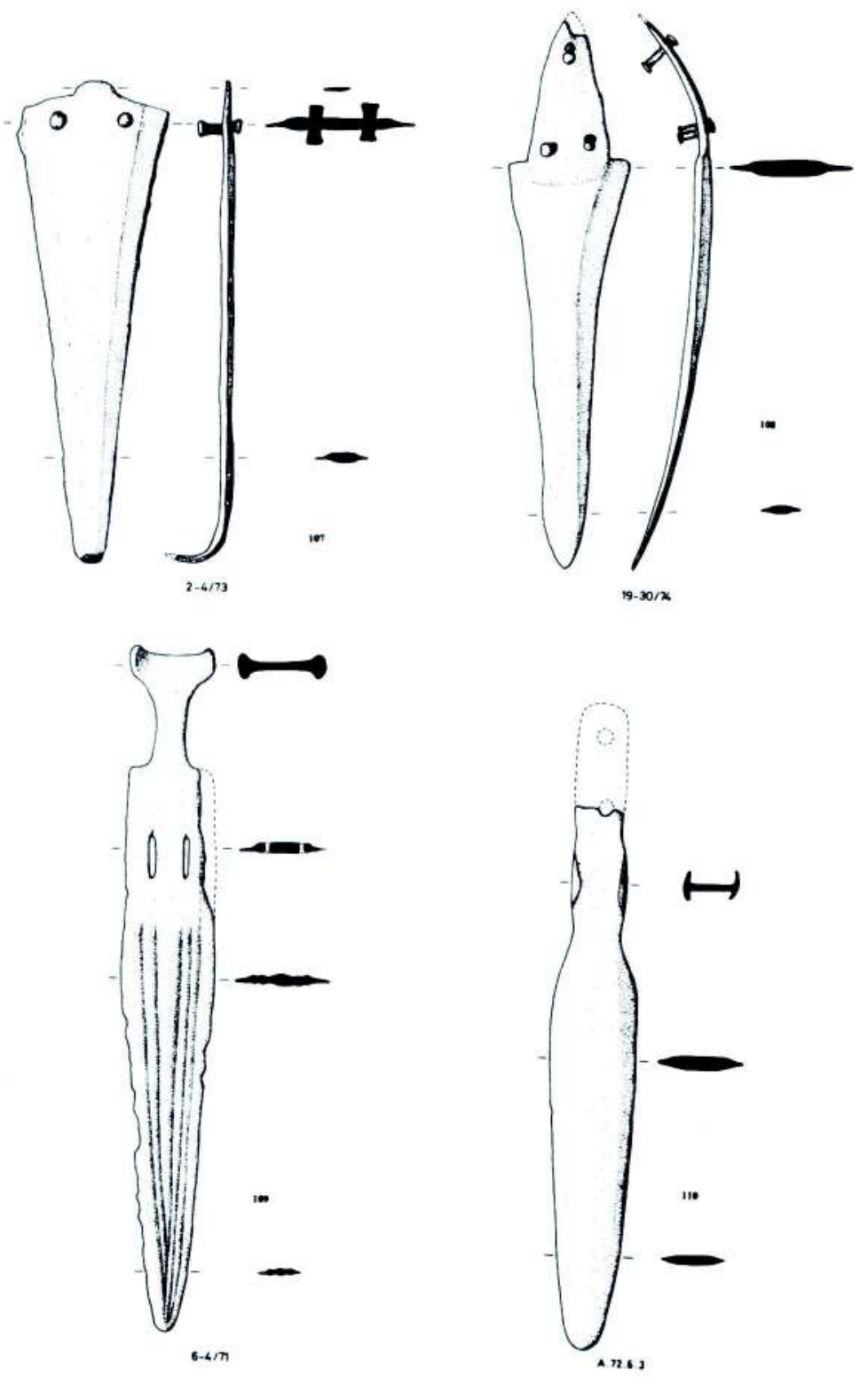

Tablo 14 SILAHLAR: Hascerler Sekt. 107-110-0TC 
Önder Bilgi

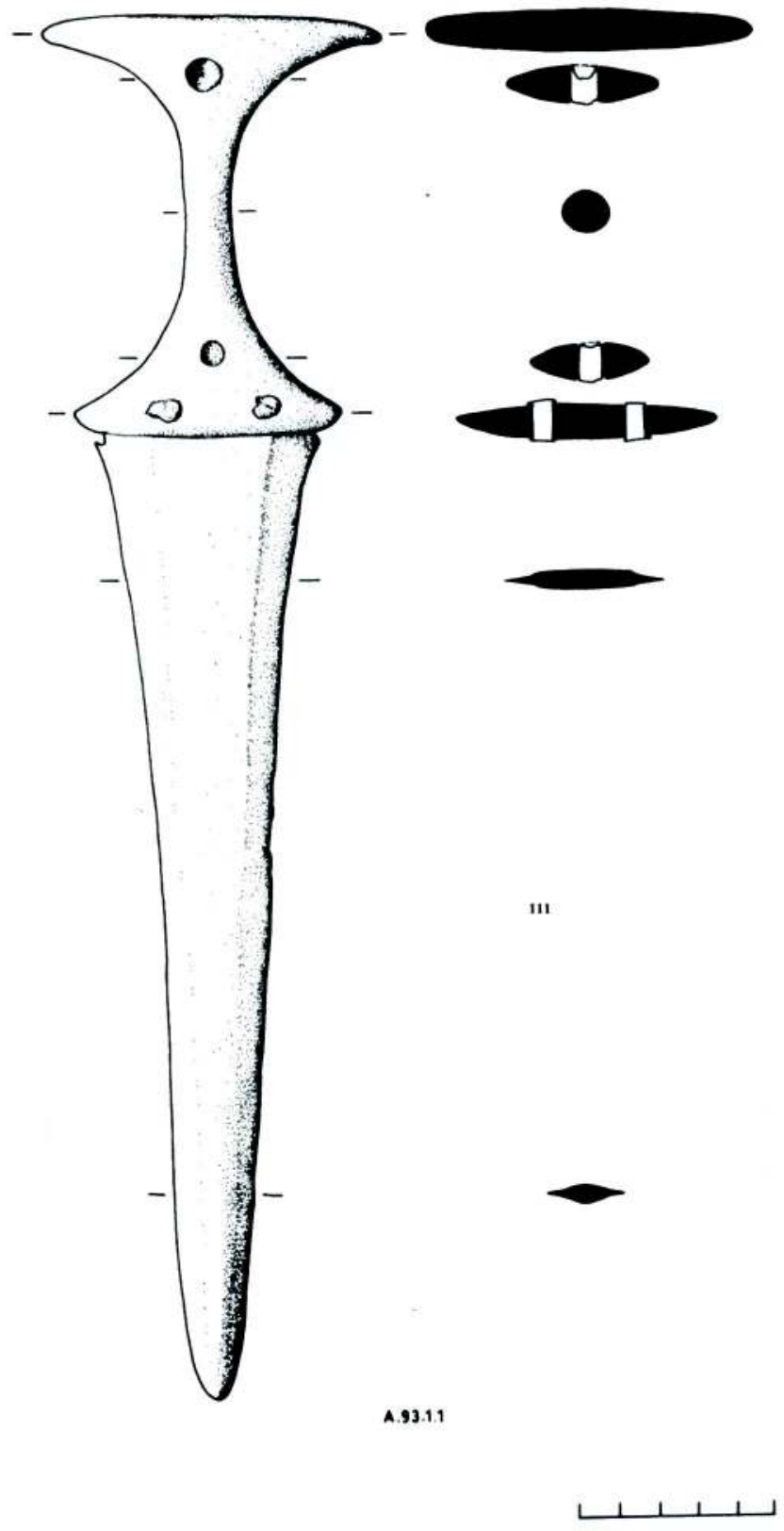

Tablo 15

StLAHLAR: Hencer \$ek, 111-GTC 
Önder Bilgi
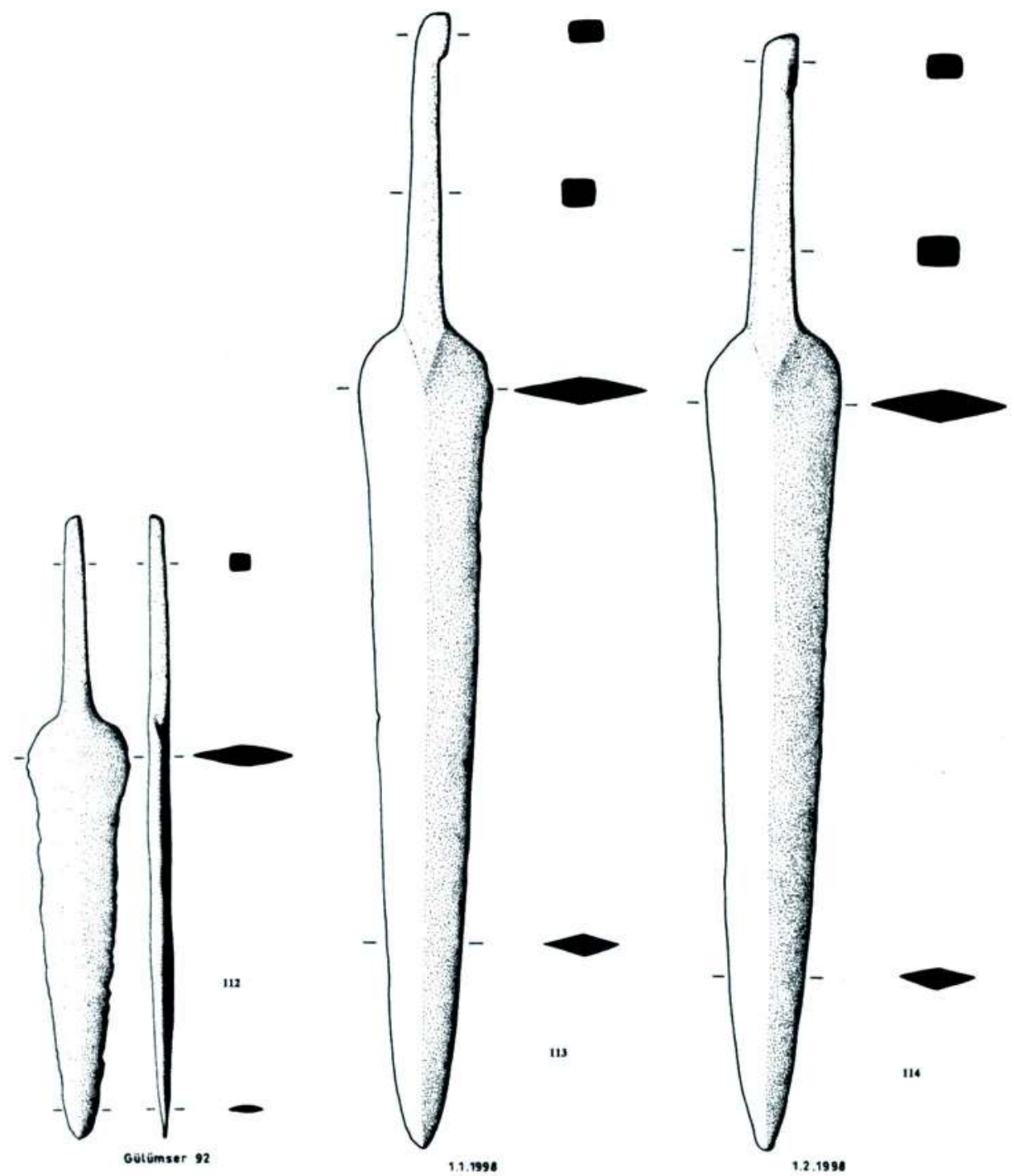

Tablo 16
StLAHLAR: Murakuclari Seth. 112-114-ITC III 
Önder Bilgi
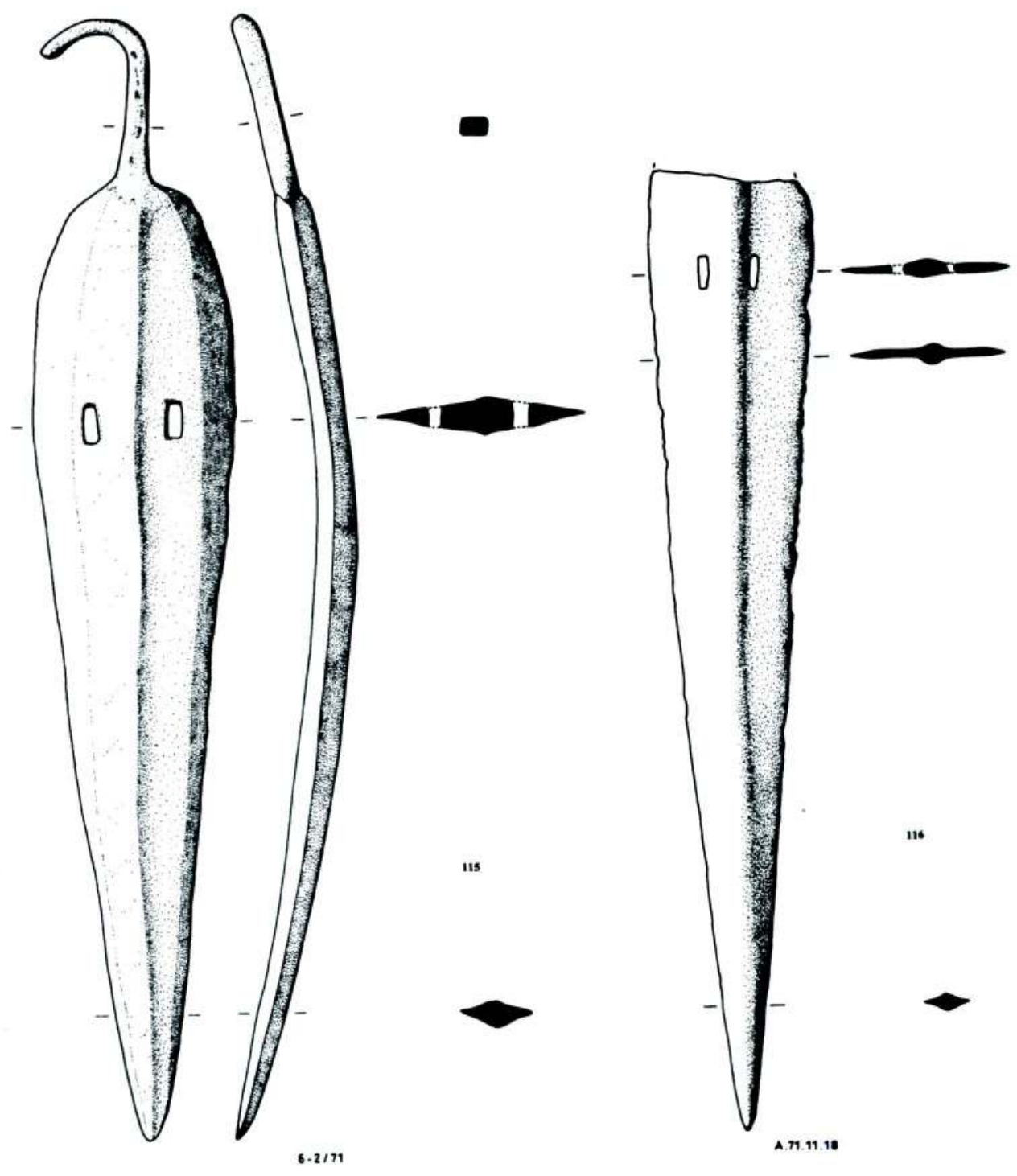

Tablo 17 Tablo 17
StLAHLAR: Murakuctarn Set. 115-116=ITC III 


\section{Önder Bilgi}
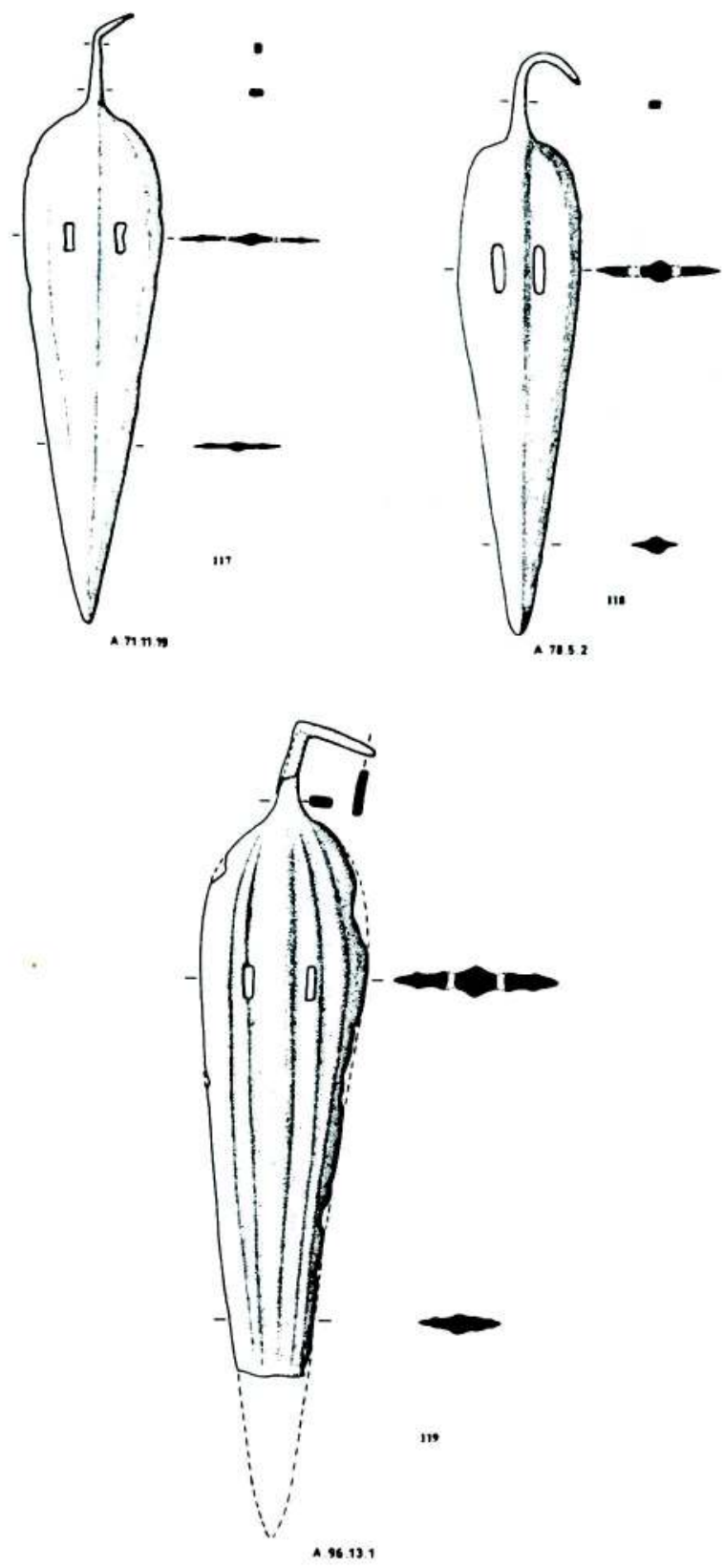

Tablo 18 
Önder Bilgi
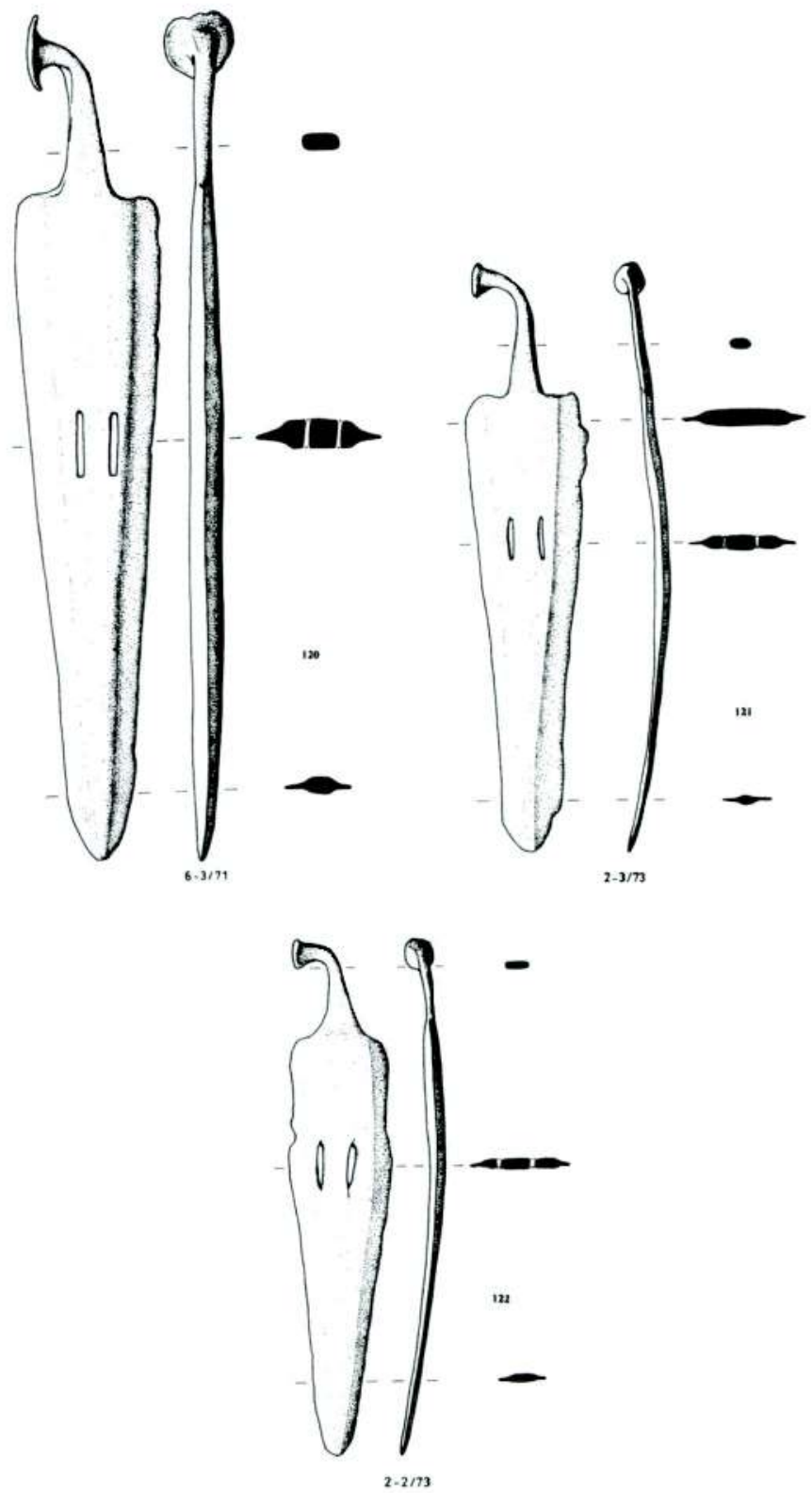

Tablo 19 StLAHL_AR: Mrrakuclari Şek. 120-122=OTC 
Önder Bilgi
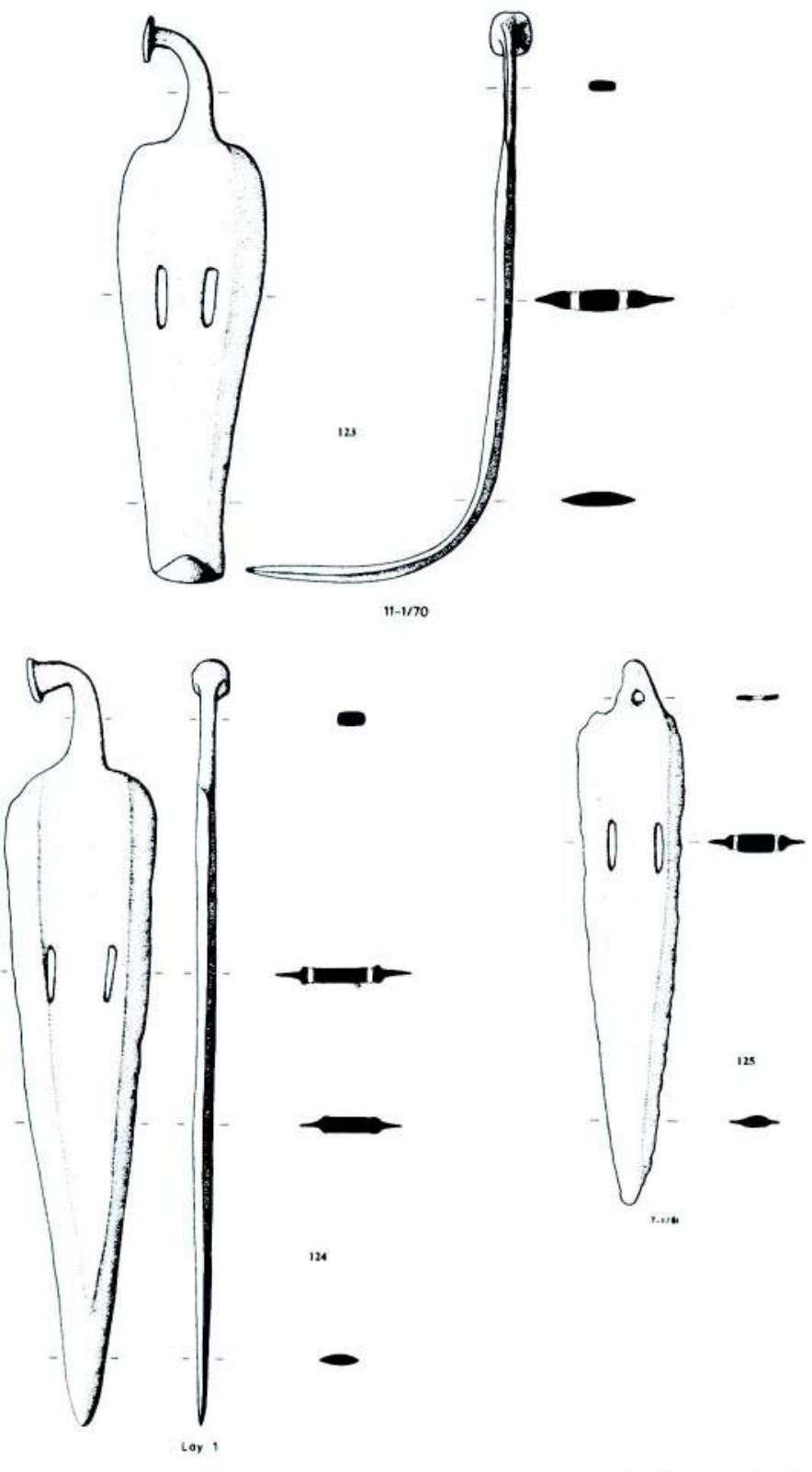

Tablo 20 SILAHL.AR: Murrakuclari Set. 123-125-OTC 
Önder Bilgi

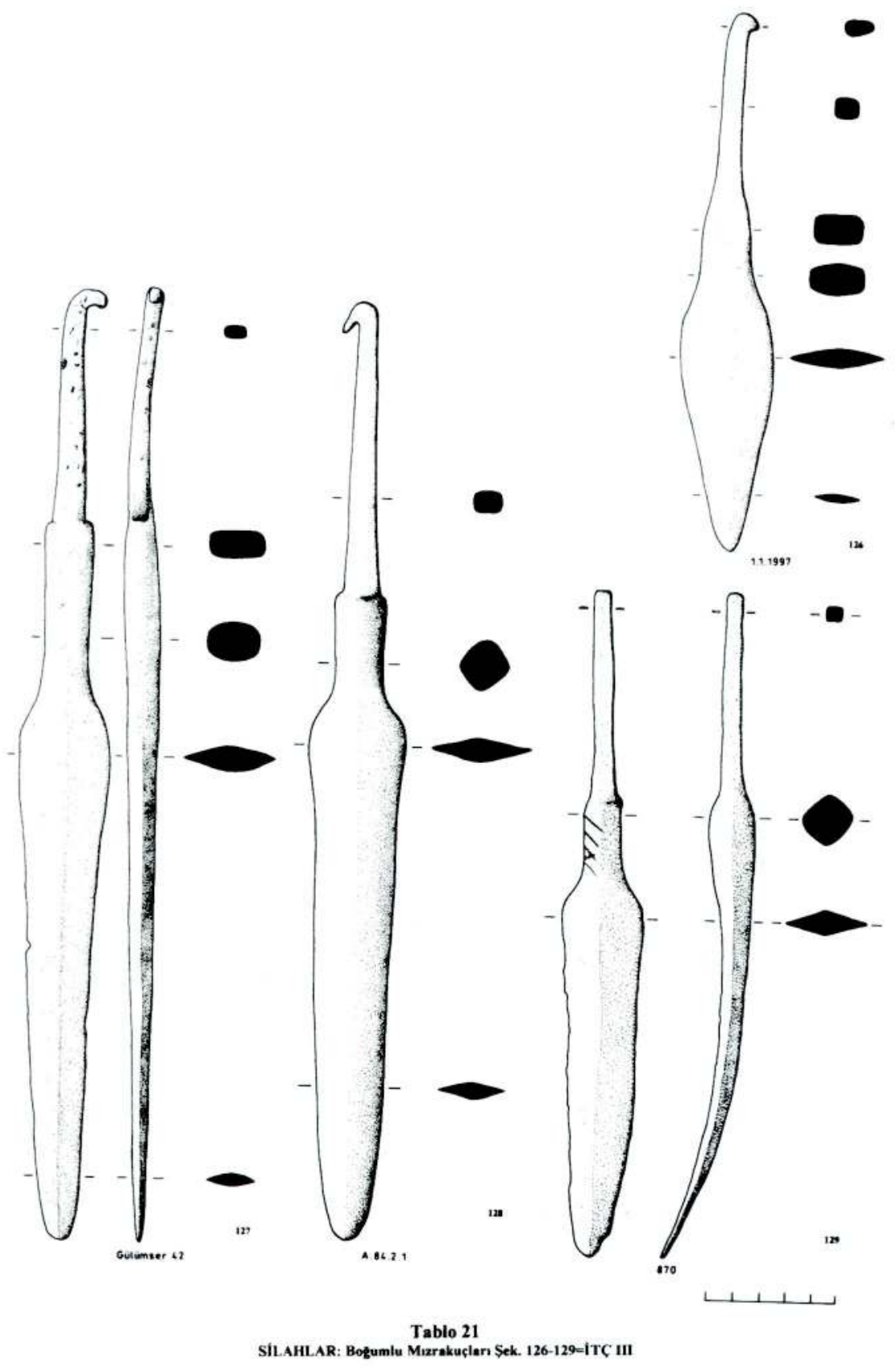




\section{Önder Bilgi}

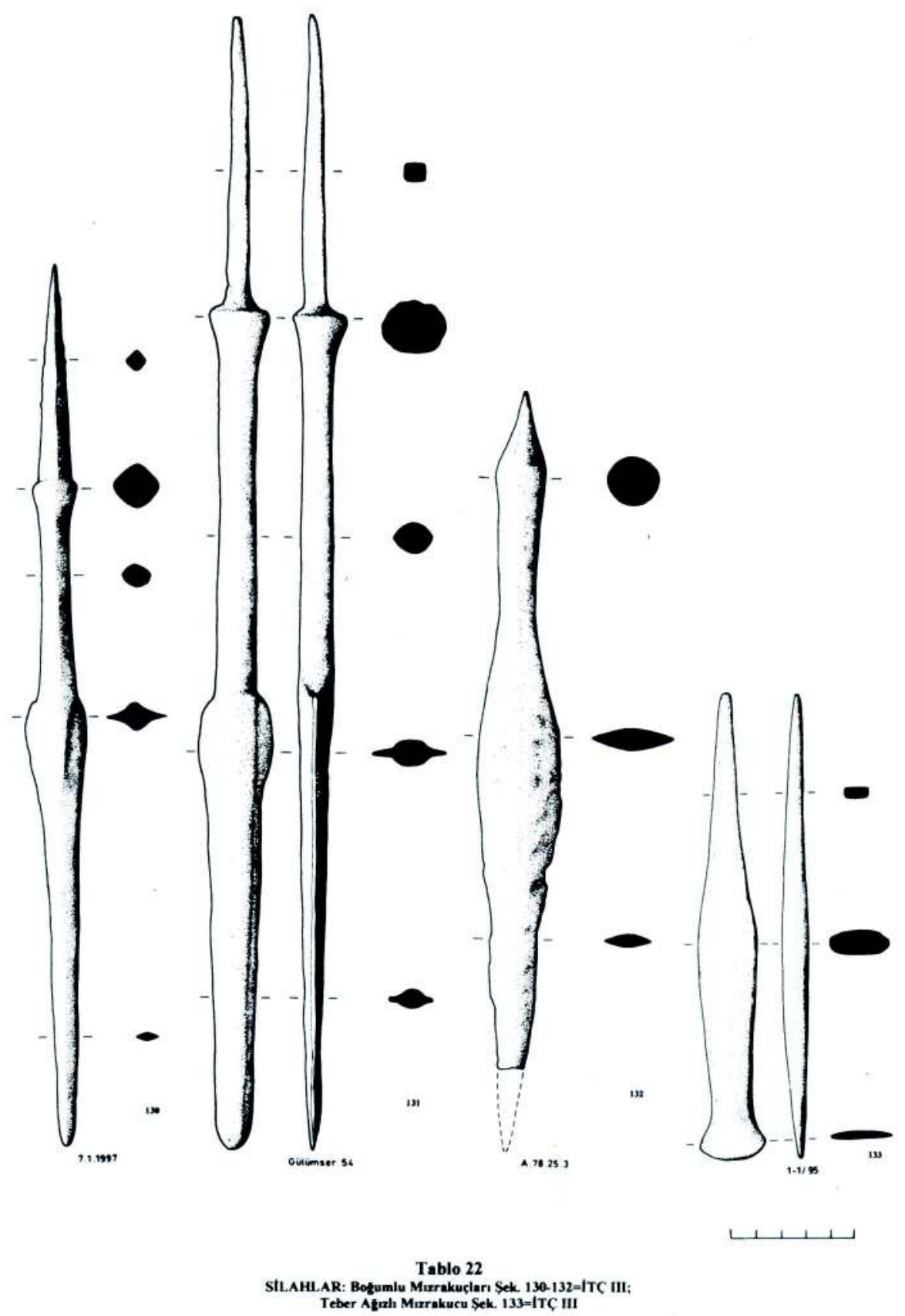


Önder Bilgi
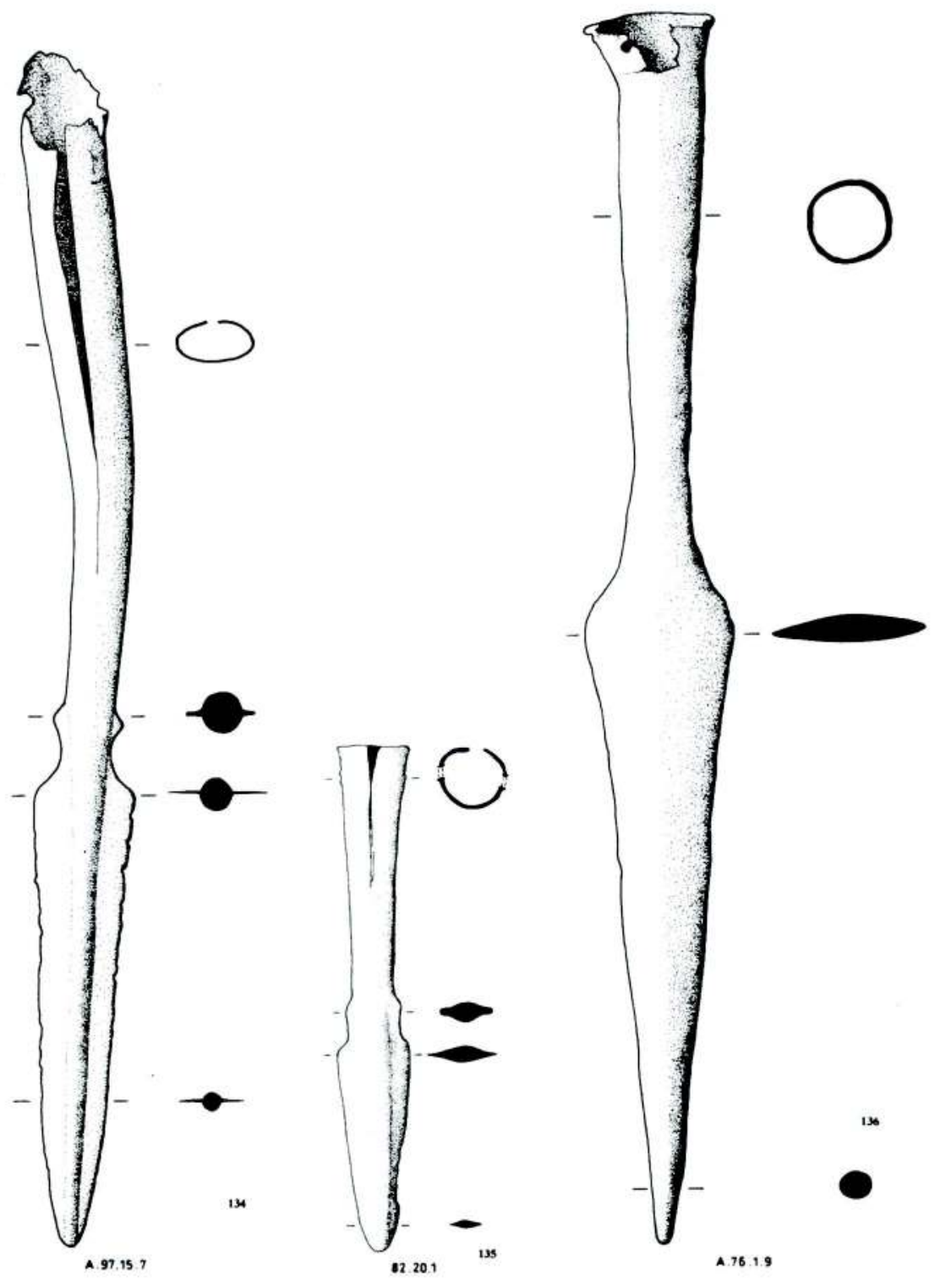

Tablo 23
SíLAHL.AR: Kovanlı Mrzrakuçları Șek 134-135=OTC, 136=GDC

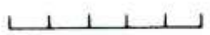




\section{Önder Bilgi}

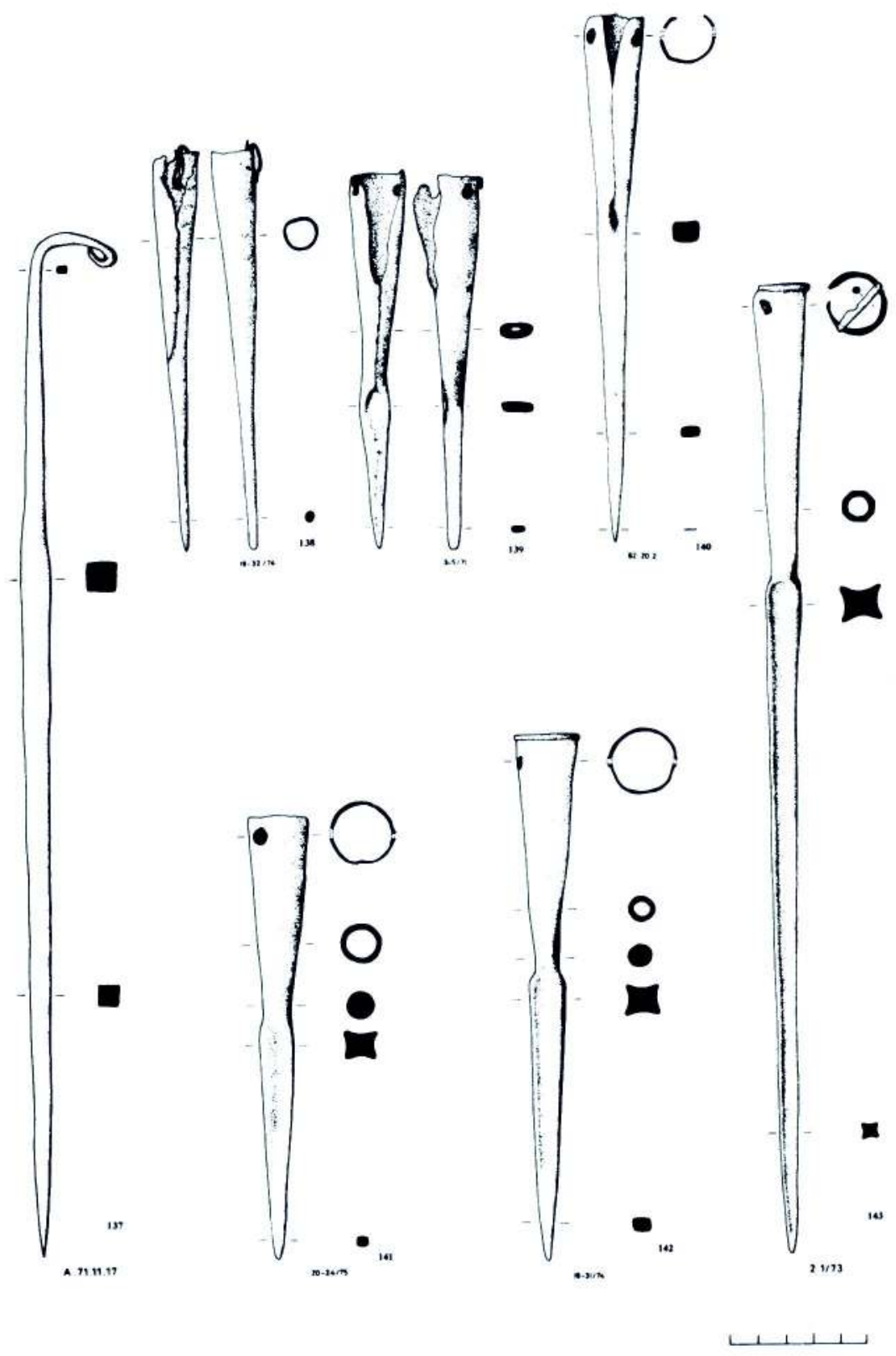

Tablo 24

SILAHLAR: Saph Kargiucu Sek, 137=ITC III; Kovanhl Kargiuclari Setk, 138-143=0TC 
Önder Bilgi

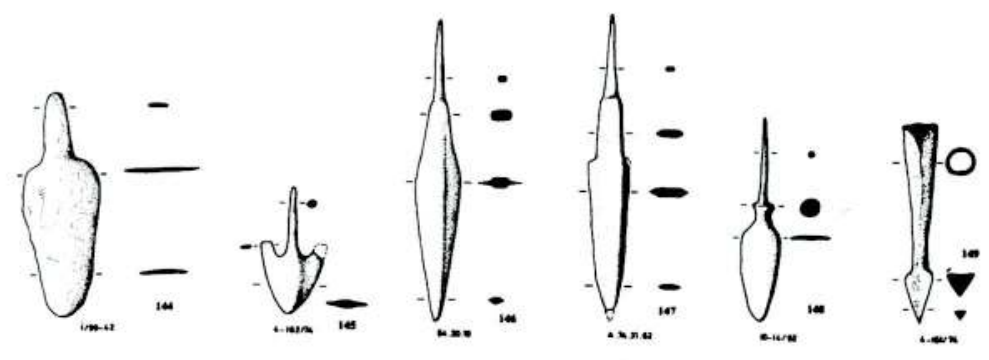

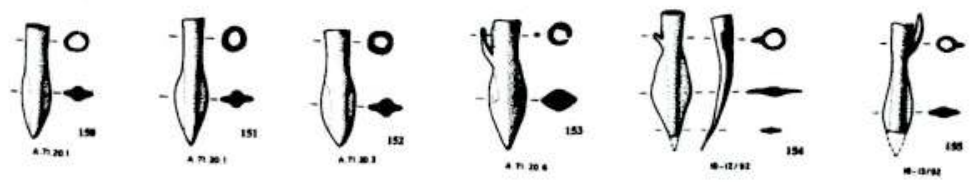
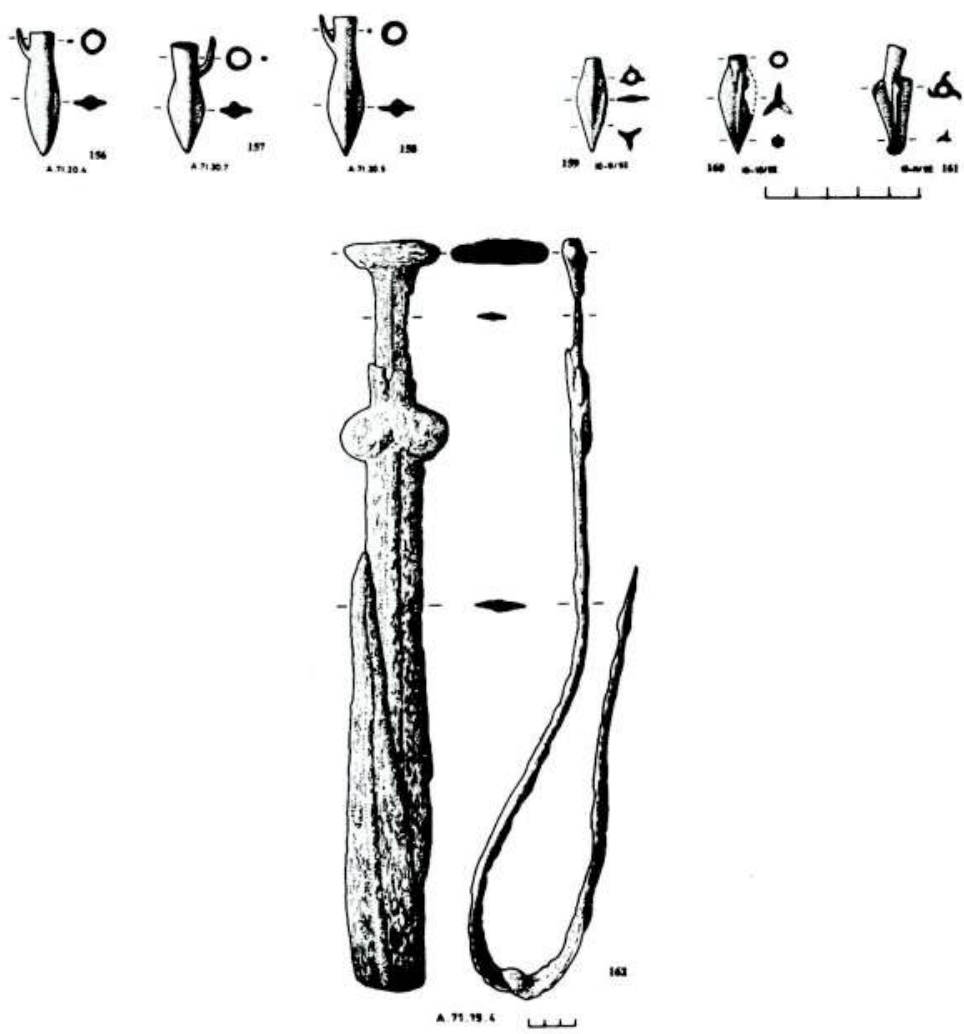

Tablo 25

SiLAHLAR: Ig̨neti Okuçiarn Sek, 144-iTC III; 145-147-OTC. 148-GDC; Kovanh Okuçiarı Sekt. 149=0TC, 150-152=GDC; Mahmuzlu Okuçlari Sek. 153-158=GDC; E, Yaprakli Namlulu Okuçiari Sek, 159-161=GDC; Kilis Sek. 162 $=$ GDC 
Önder Bilgi
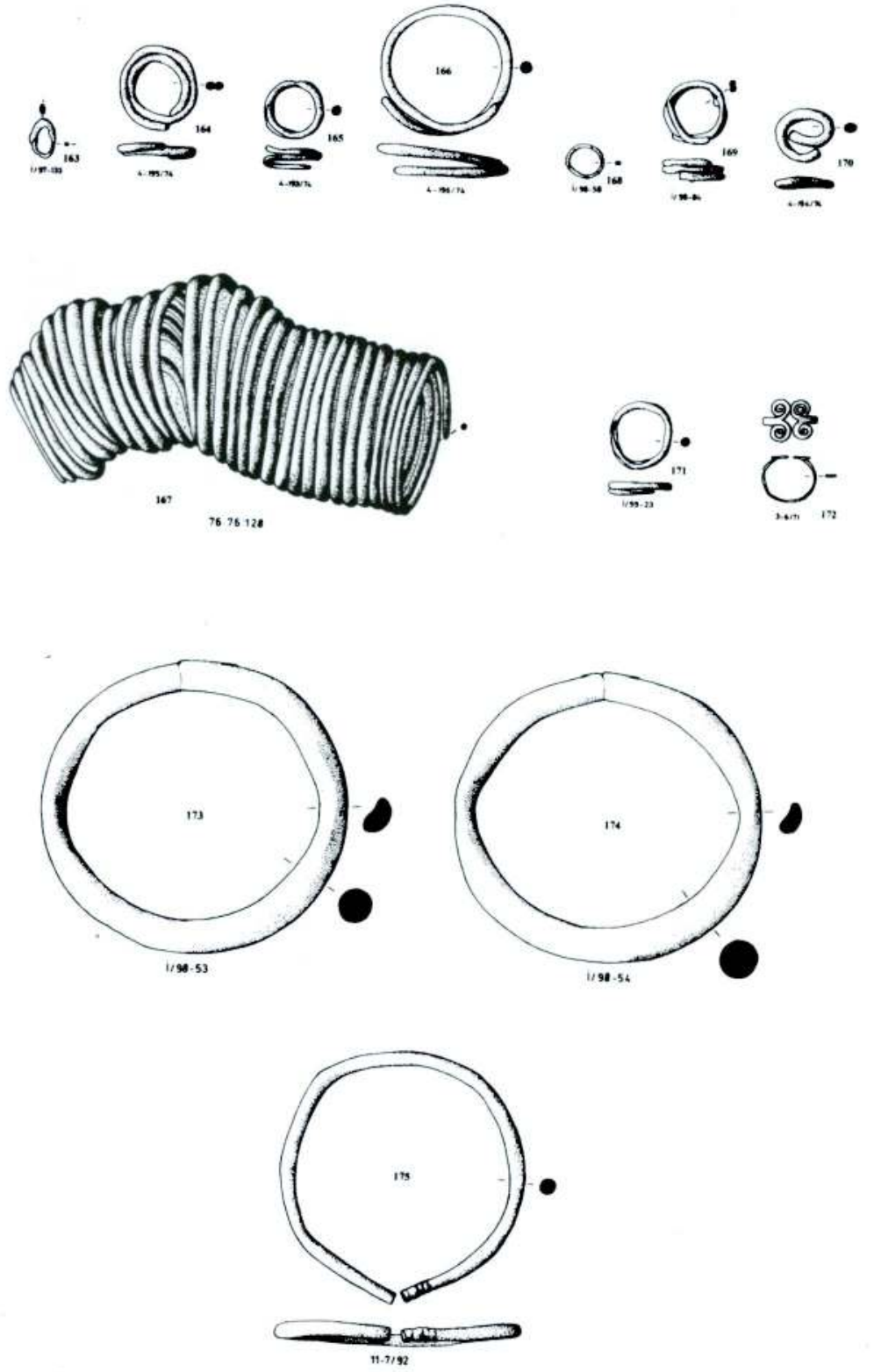

Tablo 26

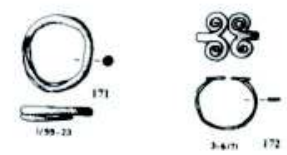

TAKIL.AR: Küpeier Șek. 163=ITC II, 164-165=1TC III; Bilezikler Sek. 166-167=1TC III; Yazakler Sek. 168-169=ITC 11, 170-171=ITC III, 172 GDC; Halhallar Sek, 173-175=iTC II 
Önder Bilgi
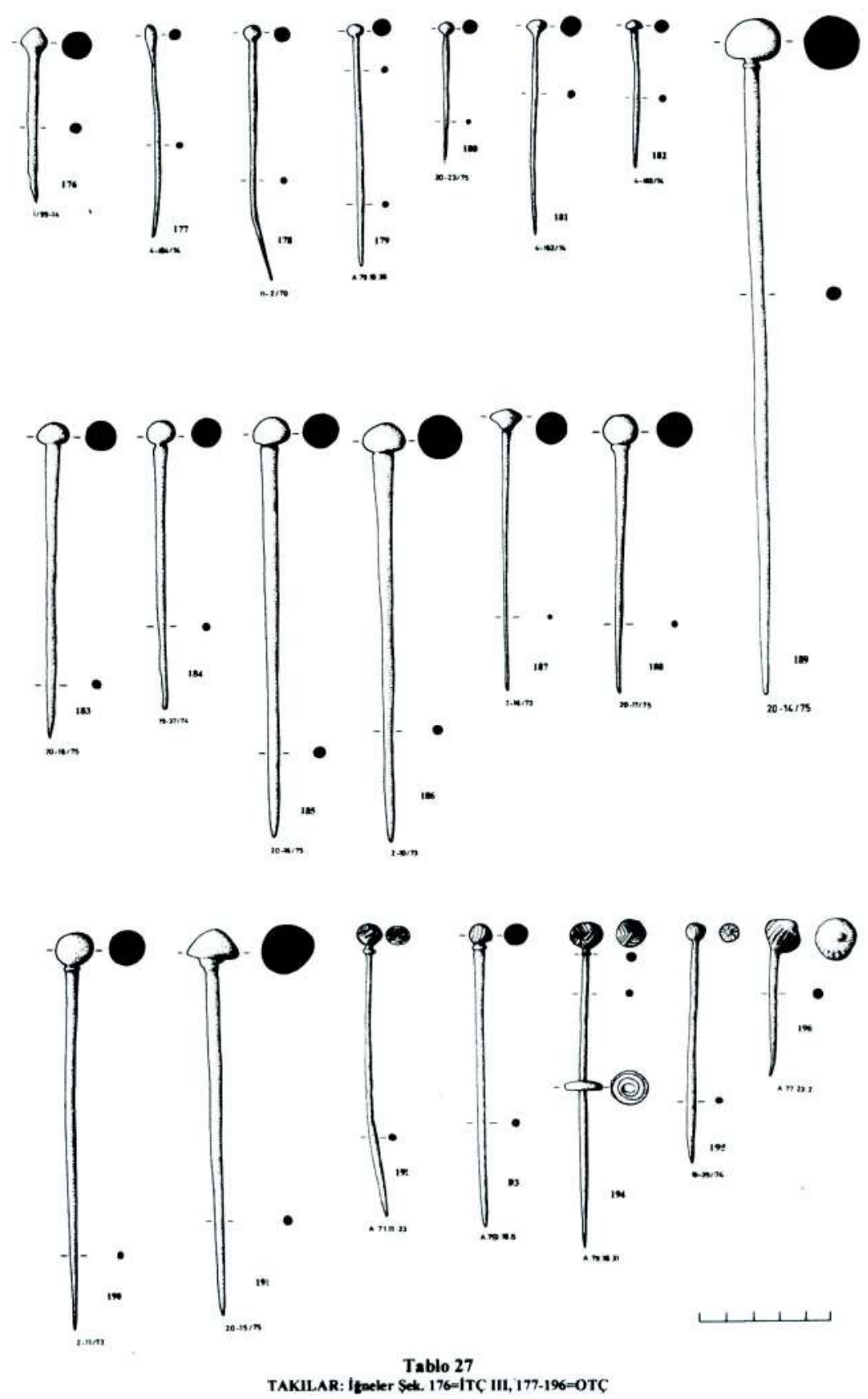
Önder Bilgi
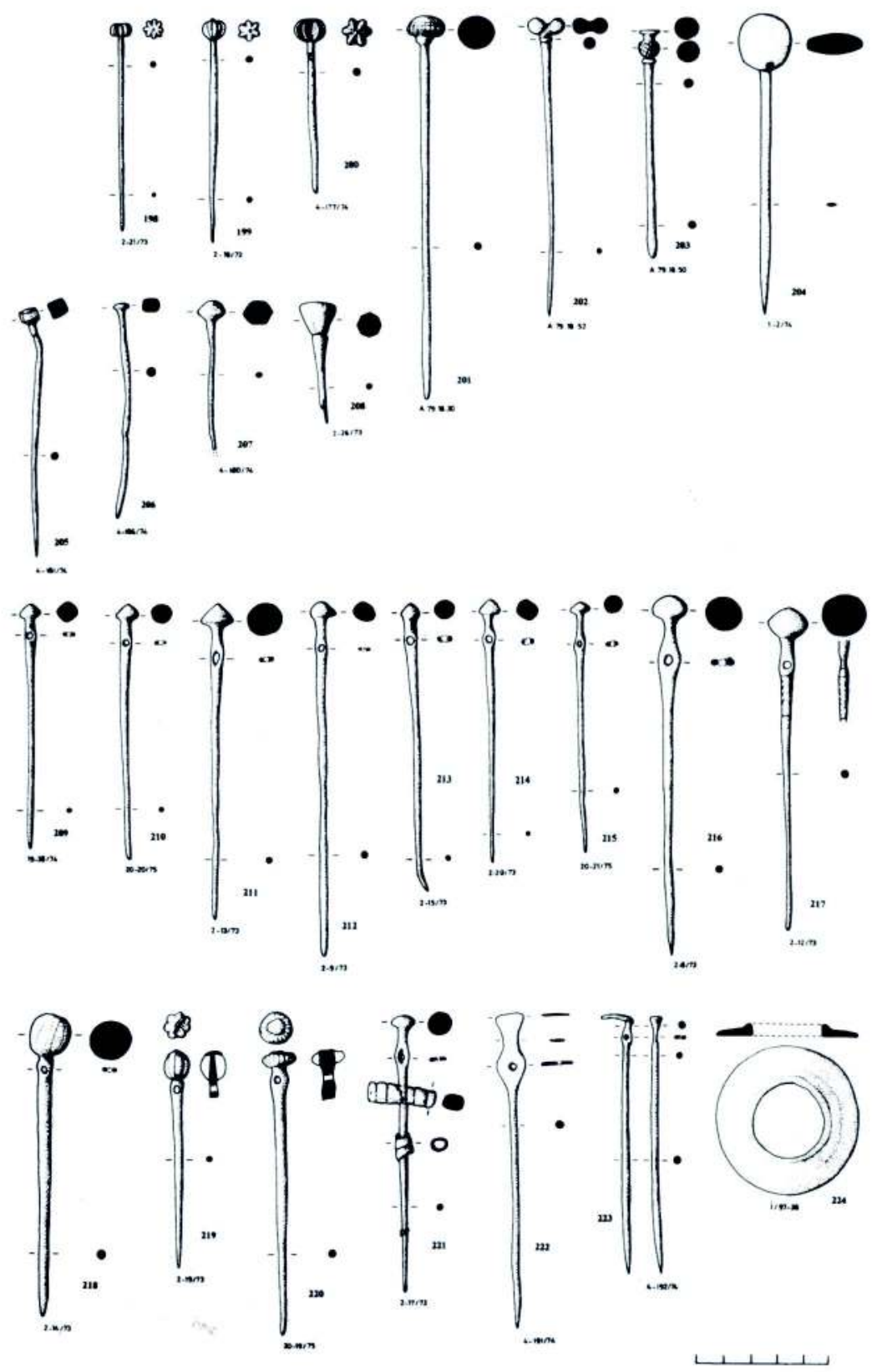

Tablo 28

TAKIL.AR: Itzeler Sẹk, 197-223=-0TC; Disk Șek. 224=HC 


\section{Önder Bilgi}
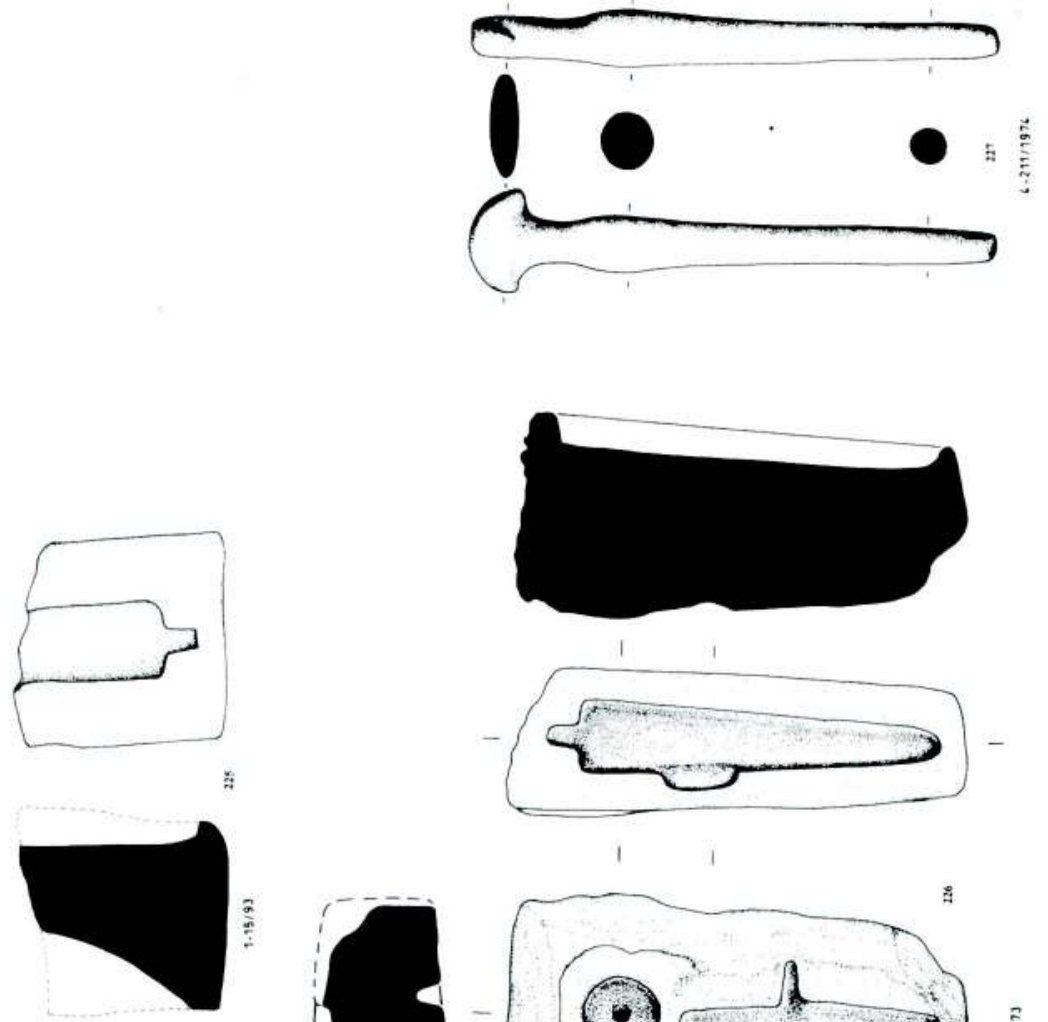

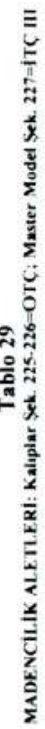
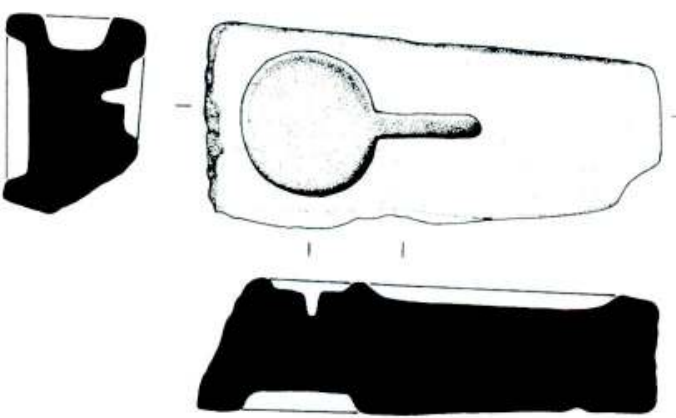
Önder Bilgi
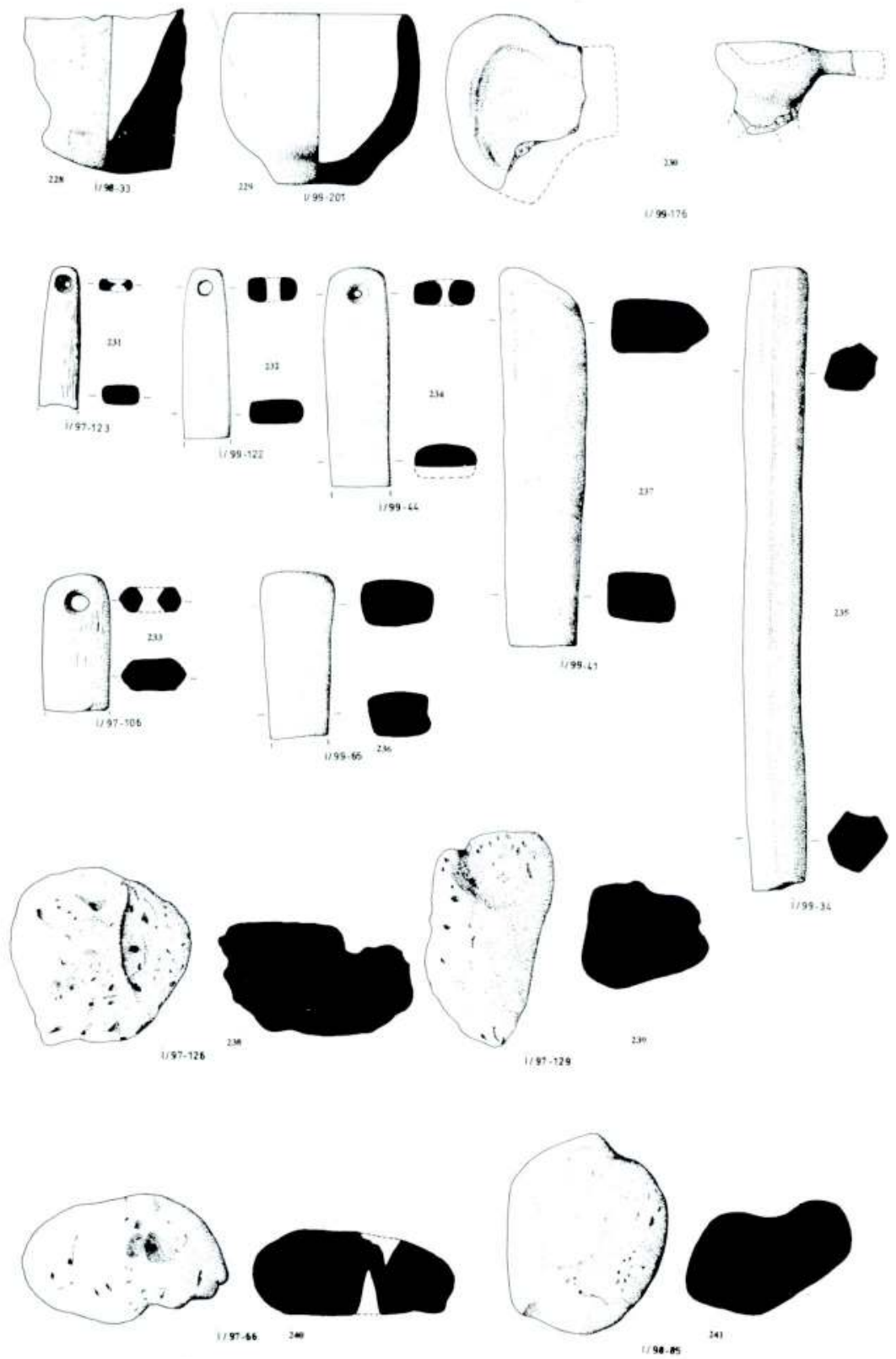

Tablo 30

MADENCILIK AI.ETIERI: Potalar Sek. 228-230-ITC II; Bileytasiari Sek. 231-233-iTC II 234-237-1TC III; 7imparalar Sek. 2.38-24I=ITC II 